Rosana Corrêa Lobo

INFERNO PROVISÓRIO:

representações do Brasil fora

da ordem e do progresso

Tese de doutorado

Tese apresentada ao Programa de Pósgraduação em Literatura, Cultura e Contemporaneidade do Departamento de Letras da PUC-Rio como parte dos requisitos parciais para a obtenção do título de Doutora em Letras.

Orientador: Prof. Renato Cordeiro Gomes

Rio de Janeiro Agosto de 2014 


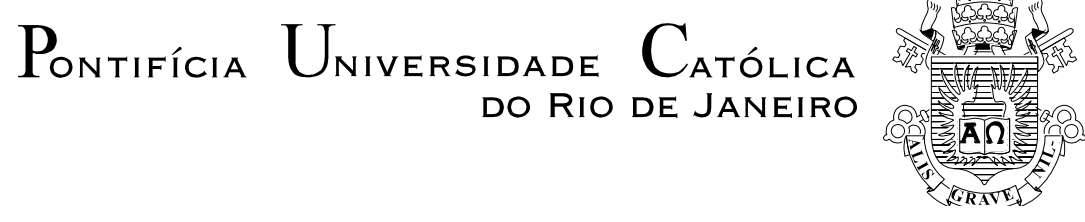

Rosana Corrêa Lobo

\title{
INFERNO PROVISÓRIO: representações do Brasil fora da ordem e do progresso
}

Tese apresentada como requisito parcial para obtenção do grau de Doutor pelo Programa de Pós-Graduação em Literatura, Cultura e Contemporaneidade do Departamento de Letras do Centro de Teologia e Ciências Humanas da PUC-Rio. Aprovada pela Comissão Examinadora abaixo assinada.

\author{
Prof. Renato Cordeiro Gomes \\ Orientador \\ Departamento de Letras - PUC-Rio
}

Prof. Julio Cesar Valladão Diniz

Departamento de Letras - PUC-Rio

Profa. Giovanna Ferreira Dealtry

Departamento de Comunicação Social - PUC-Rio

Prof. Alexandre Graça Faria

UFJF

Profa. Beatriz Vieira de Resende

UFRJ

Profa. Denise Berruezo Portinari Coordenadora Setorial do Centro de Teologia

e Ciências Humanas - PUC-Rio

Rio de Janeiro, 29 de agosto de 2014. 
Todos os direitos reservados. É proibida a reprodução total ou parcial do trabalho sem autorização do autor, do orientador e da universidade.

Rosana Corrêa Lobo

Graduou-se em Comunicação Social pela UFRJ em 2003. Cursou mestrado em Literatura Brasileira na PUC-RIO entre 2008 e 2010 e Doutorado em Literatura, Cultura e Contemporaneidade, entre 2010 e 2014. Desde de 2008, vem se dedicando à atividade de pesquisa na área de Cultura Brasileira, tanto na academia quanto em atividades extra acadêmicas como exposições, documentários, programas de TV e livros. Participa assiduamente de Seminários e publica constantemente em revistas acadêmicas e periódicos locais.

Ficha Catalográfica

Lobo, Rosana Corrêa

Inferno provisório: representações do Brasil fora da ordem e do progresso / Rosana Corrêa Lobo; orientador: Renato Cordeiro Gomes. 2014.

$135 \mathrm{f.} ; 30 \mathrm{~cm}$

Tese (doutorado)-Pontifícia Universidade Católica do Rio de Janeiro, Departamento de Letras, 2014.

Inclui bibliografia

CDD:800 
À Lili dedico essa espécie de meia irmã. 


\section{Agradecimentos}

Ao meu orientador Renato Cordeiro Gomes, por ter acolhido o meu projeto e ter visto com tanta clareza a forma que ele deveria ter. Minha gratidão, carinho e admiração.

À minha família e à Nagile Farah por todo o apoio emocional e a paciência dos últimos anos.

Ao Cássio Loredano pela leitura atenta deste trabalho e as sugestões para torná-lo mais claro.

Aos meus colegas do doutorado Paulo Roberto Tonani do Patrocínio, Carolina Barcelos e Aline Novaes, pelas trocas e companhia dos últimos anos.

Aos professores que participaram da banca examinadora.

Ao CNPQ e à PUC-Rio pelos auxílios concedidos, sem os quais este trabalho não poderia ter sido realizado.

À Daniele de Oliveira Cruz pela solicitude de sempre. 


\section{Resumo}

Lobo, Rosana Corrêa; Gomes, Renato Cordeiro. Inferno provisório: representações do Brasil fora da ordem e do progresso. Rio de Janeiro, 2014. 135 p. Tese de doutorado - Departamento de Letras, Pontifícia Universidade Católica do Rio de Janeiro.

Investigação de como se configura a representação do imaginário nacional na literatura contemporânea a partir da saga Inferno provisório, de Luiz Ruffato, publicada em cinco volumes pela editora Record. Num tempo em que a narrativa da nação se faz ficção desnecessária, por ser fruto de contingências históricas já ultrapassadas, o autor resiste à estandardização cultural desencadeada pelo processo de globalização, sem cair no anacronismo da representação essencialista, totalizante e homogênea da nação. Quando os conceitos de razão, ciência e história linear são postos em xeque, o autor constrói através da fragmentação uma representação ao mesmo tempo crítica e afetiva de um Brasil fora da ordem e do progresso.

\section{Palavras-chave}

Brasil; nação; identidade; Luiz Ruffato; Inferno provisório. 


\section{Abstract}

Lobo, Rosana Corrêa; Gomes, Renato Cordeiro (Advisor). Provisional hell (Inferno provisório): Representations of a Brazil out of order and progress. Rio de Janeiro, 2014. 135 p. Doctoral thesis - Departamento de Letras, Pontifícia Universidade Católica.

Investigation of the representation of the national imaginary in the contemporary literature departing from the saga Provisional hell, "Inferno Provisório", by Luiz Ruffalo published in five volumes by the publishing house Record . In a time when the narrative of the nation seems to be unnecessary fiction, since it results from outdated historical contingencies, the author resists the cultural standardization triggered by the process of glabalization, without incurring in the anachronism of the essentialist, totalizing and homogenic representation of the nation. When the concepts of reason, cience, and linear history are at stake, the author builds, through fragmentation, a representation that is both critical and affective, from a Brazil that is alien to order and progress.

\section{Keywords}

Brazil; nation; identity; Luiz Ruffato; Provisional hell (Inferno provisório). 


\section{Sumário}

$\begin{array}{ll}\text { 1. Introdução } & 10\end{array}$

2. Como pensar a nação hoje 23

2.1. Do paraíso ao inferno 29

3. Como chegamos até aqui 39

3.1 Mamma son tanto felice ou os problemas 42 de hoje e de sempre

3.20 mundo inimigo regido pelo consumo 54

3.3 Vista parcial da noite: lados de um mesmo Brasil 66

$\begin{array}{ll}3.4 O \text { Brasil urbano } & 74\end{array}$

4. Inferno provisório sob o signo da ruína 87

4.1 Fora da Ordem e do progresso 94

5. Considerações finais 110

$\begin{array}{ll}\text { 6. Referências Bibliográficas } & 120\end{array}$

$\begin{array}{ll}\text { Anexo I - Discurso de Frankfurt } & 128\end{array}$

$\begin{array}{ll}\text { Anexo II - Entrevista } & 133\end{array}$ 
- Eu lembro de tudo...

- De tudo?

- De tudo..

- Eu não me lembro de porra nenhuma...

- Bom pra você...

- Bom?

- É.

- Por quê, bom?

- Pelo menos assim você não sofre...

- Não sofro?

- Eu lembro de tudo...E isso machuca a gente...

(trecho do episódio, Zezé \& Dinim, Inferno provisório, v. 4, p. 150-151) 


\section{Introdução}

Já se tornou lugar-comum na historiografia da literatura brasileira afirmar a tradição de um cânone que faz da estrutura literária moldura para interpretar o país. A fortuna crítica sobre o tema indica que a nação, no período de sua consolidação, necessitou de crenças que, transmitidas culturalmente, fossem capazes de promover a coesão nacional. Assim, como bem define Vera Follain de Figueiredo, “a nação é uma invenção, não porque seja mentira, mas porque depende para sua existência de atos coletivos de imaginação, expressos através dos meios de comunicação: livros, jornais, panfletos, etc.” (FIGUEIREDO, 1999, p. 74).

Dessa forma, a nacionalidade como fenômeno moderno, exigia o incentivo para produzir e consumir uma literatura que definisse uma identidade comum. "Essa identidade se teceu a partir de relatos acerca do passado histórico do povo que habitava o território que se queria definir como nacional. Tratava-se de realizar uma reinterpretação fundadora, que passava pela criação de mitos", que, registrados através da literatura, funcionavam como "cimento ideológico" para a edificação da jovem nação (Idem, 74-75). É o que se deu no Romantismo, por exemplo, nos romances de José de Alencar.

A condição de país colonizado impôs ao Brasil, sobretudo a partir de sua independência política, em 1822, a necessidade de se criar uma literatura diferente da transplantada de Portugal. Neste período os escritores brasileiros almejam produzir uma literatura equivalente às europeias, que exprimisse de maneira adequada a sua realidade própria, ou como se dizia, 'uma literatura nacional'.

$\mathrm{Na}$ época, o poeta para ser nacional tinha que harmonizar as tradições indígenas com as portuguesas e a literatura tinha o intuito de contribuir para a grandeza da nação. Como afirma Antonio Candido, em sua Formação da literatura brasileira, "manteve-se durante todo o romantismo esse senso de dever patriótico, que leva os escritores não só a cantar a sua terra, mas a considerar as suas obras como contribuição ao progresso" (CANDIDO, 2006, p. 328). 
A vontade de afirmação da jovem nação se projeta, então, na invenção de uma nova tradição, diferente da portuguesa. Esse afirmar da 'essência nacional' estaria, no entanto, segundo o orientador dessa pesquisa, atrelado a um paradoxo: "nega-se uma tradição que, ao mesmo tempo, é reinterpretada na tentativa de preencher aquele vazio com narrativas, imagens, ideias que contribuiriam para a formação de mitos fundadores da nacionalidade" (GOMES, 2002, p. 129).

Era preciso esquecer toda uma realidade indesejável herdada da tradição portuguesa para elaborar uma imagem única, totalizante, de uma nação reconciliada. A herança colonial portuguesa é submetida a um processo de ressemantização para justificar a nova nação: “A narrativa romântica brasileira propõe uma 'comunidade imaginada' (Benedict Anderson) enquanto totalidade estável e a identidade cultural enquanto essência fundadora resultante da conciliação de colonizador e colonizado" (Idem, p. 130).

O período é para Abel Barros Baptista, "um momento verdadeiramente fundador [para a literatura brasileira], não só porque só então ela comece, mas porque aí se coloca o problema do seu começo". A partir desse período, a literatura brasileira se estrutura dominantemente como interpretação do Brasil, e a busca da nacionalidade literária se confunde com a construção do imaginário nacional. "Ao mesmo tempo que fundavam o projeto de literatura nacional, os românticos inventavam o Brasil”, (BAPTISTA, 2003, p. 24).

Ao deixar de saudar o "Deus do Politeísmo Grego" para começar a tratar de questões mais ligadas à nossa realidade e imprimir um abrasileiramento à língua portuguesa, os escritores românticos garantem à literatura brasileira uma certa “independência literária". Esta geração, no entanto, traz em seu bojo um "brasileirismo de superfície", uma vez que teve pouca ousadia para abordar os problemas brasileiros intimamente. A tendência ao esquecimento e apagamento de uma realidade nacional indesejada neste período é tão forte que, como chama a atenção Lilia Schwarz, no prefácio de Comunidades Imaginadas, em pleno século XIX nos entendíamos como europeus ou no máximo indígenas, num país em que mais de $80 \%$ da população eram constituídas de negros e mestiços. Na representação oficial, diz a antropóloga, “'esquecemos’ a instituição escravocrata - espalhada por todo o país - e exaltamos a natureza provedora dos trópicos, como 
se o país fosse feito basicamente da imagem de sua flora exuberante" (2008, p. 16).

As narrativas românticas lançam a semente da ideologia da conciliação pacífica de interesses divergentes ocultando a violência da conquista colonial e as contradições do discurso emancipatório do Brasil do século XIX. Inventam uma identidade "apagando ou recalcando algo que positivamente existia, a violência dos processos coloniais e do sistema escravista, a multidão de negros que povoavam o país" - e ao mesmo tempo, criam algo que nunca existiu: "o consórcio harmonioso entre o colonizador e o habitante natural da terra, a condescendência com o belo índio, o elogio e a heroicização do sacrifício da cultura autóctone" (CUNHA, 1997-98, p. 179-80).

Na contramão do romantismo, Machado de Assis, em 1873, no ensaio Literatura Brasileira - Instinto de Nacionalidade, reivindica a liberdade temática. "Não estabeleçamos doutrinas tão absolutas que nos empobreçam" (Idem, p. 135). Dizia que "um poeta não é nacional só porque insere nos seus versos muitos nomes de flores e de aves do país, o que pode dar uma nacionalidade de vocabulário e nada mais". (Idem, p. 144). E para provar que a nacionalidade de um escritor não residia em sua temática, deu o exemplo de Shakespeare, que apesar de não tratar da história inglesa ou do território britânico em Hamlet, Otelo, Júlio César e Romeu e Julieta, nem por isso deixou de ser um poeta essencialmente inglês: "O que se deve exigir do escritor, antes de tudo, é um certo sentimento íntimo que o torne homem de seu tempo e do seu país ainda que trate de assuntos remotos no tempo e no espaço" (Idem, p. 135).

Apesar de tais reivindicações por liberdade de expressão, críticos como Afrânio Coutinho e Astrojildo Pereira, como conta Abel Barros Baptista em $A$ formação do nome, se esforçaram para restituir a obra de Machado ao projeto nacional. Para eles, sem ser nacionalista, Machado teria sido um escritor nacional e popular, pois não escrevia de costas para a sua nação. Sua obra refletia os problemas de seu povo, seus costumes, preocupações, ideais e dificuldades (BAPTISTA, 2003, p. 45-55). Abel acredita, no entanto, que o enquadramento da obra de Machado no contexto nacional é empobrecedor e que todo grande escritor 
está ao mesmo tempo dentro e acima da literatura a que pertence. Ele afirma que Machado procura

mostrar que o "instinto de nacionalidade" não constitui missão ou obrigatoriedade para os escritores, é apenas o "primeiro traço" da literatura brasileira no estado em que se encontra, ou seja, é apenas uma tendência literária entre outras possíveis que nada torna verdadeiramente mais importante ou mais legítima que qualquer outra (2003, p. 63)

Também Joaquim Nabuco em Minha formação dizia: "Sou antes um espectador do meu século do que do meu país", dando preferência à crise da representação por que passava a modernidade à identidade nacional que a jovem nação buscava (In: SANTIAGO, 2003, p. 13). Nabuco se interessava mais pela civilização, que era como uma peça sendo encenada em todos os teatros da humanidade, do que pelas paisagens do Novo Mundo. Numa passagem de Minha Formação, o abolicionista afirma que as paisagens daqui não valiam para ele um trecho da via Appia ou um pedaço do cais do Sena à sombra do velho Louvre. Daí o termo "moléstia de Nabuco", cunhado por Mário de Andrade em carta a Carlos Drummond de Andrade, na qual o mineiro é repreendido por suas inclinações afrancesadas. Tal moléstia consistia em brasileiros, como Drummond e Nabuco, sentirem saudades do Sena em plena Quinta da Boa Vista.

No início do século XX, Euclides da Cunha, em Os sertões (1902), inaugura uma visão diferente da terra, da gente, da realidade histórica e social brasileira. "Foi uma visão nova do Brasil e seus problemas que nasceu com o livro", lembra o verbete da Enciclopédia de Literatura Brasileira, organizada por Afrânio Coutinho e J. Galante de Souza (2001, p. 569). Marco na vida mental do Brasil, a epopeia mistura ensaio, história, ciências naturais, lirismo e drama e dá um passo importante na conquista da consciência de brasilidade pela vida intelectual do país, além de ser decisivo para o desenvolvimento dos estudos brasileiros.

Já em 1922, o movimento Modernista nos liberta de uma série de recalques históricos, sociais e étnicos, de modo que as nossas deficiências passam a ser interpretadas como potenciais superioridades. Como avalia Antonio Candido, não 
era mais preciso escrever que tudo aqui era belo e risonho. A rudeza, os perigos, os obstáculos da natureza tropical são acentuados; o mulato e o negro incorporados como temas de estudo, inspiração, exemplo e o primitivismo é agora fonte de beleza e não mais empecilho à elaboração da cultura (CANDIDO, 2006, p. 127).

Como depois da Primeira Guerra Mundial (1914-18), o Brasil se encontra mais ligado comercial e culturalmente ao Ocidente europeu, os nossos modernistas vão reencontrar a influência europeia por um mergulho no detalhe brasileiro, priorizando o caráter estético da nação, elaborando criticamente a nossa cultura, dando expressão ao nosso folclore de maneira bastante irreverente, como Oswald e Mário de Andrade. Esse período foi responsável pela descoberta de símbolos e alegorias bastante sugestivos da nossa cultura, como, por exemplo, a antropofagia, conceito que inaugura uma emancipação cultural, em que mestiçagem, ingestão e contaminação permanente de perspectivas tornam-se estratégias possíveis para definir a arte latino-americana, cuja fragmentação e cujo hibridismo se contrapõem aos esquemas cristalizados da unidade e da autenticidade. $\mathrm{O}$ conceito de antropofagia permite pensar em formações culturais híbridas, heterogêneas e desinibidas em relação às questões de originalidade e procedência.

O movimento modernista pretendeu, como escreveu Mário de Andrade em carta a Joaquim Inojosa, em 1924, promover a entrada do Brasil no "concerto das nações cultas". Para isso, era preciso concorrer "com a sua parte pessoal, com o que o singulariza, com o que o individualiza, parte essa única que poderá enriquecer e alargar a civilização" (MORAES, 2002). A fronteira é entendida nesse momento não como algo que restringe, mas como algo que abre possibilidade de contato e participação na vida moderna, como resume Eduardo Jardim de Moraes, no artigo $O$ que significa ir além das fronteiras?: “Apenas à medida em que a cultura nacional apresentar uma fisionomia própria, em que suas características forem delimitadas, ela comungará os ideais modernos universais" (Idem).

Este mesmo autor lembra em outro ensaio, Modernismo revisitado, que o movimento propunha uma renovação a partir da nacionalização das fontes de 
inspiração do artista brasileiro. "O que importa não é apenas compatibilizar o que é moderno e o que é nacional. Importa mais apresentar o moderno como necessariamente nacional" (MORAES, 1998, p. 221). Dessa forma, prossegue o autor, "a rejeição da problemática do nacionalismo trazia consigo a recusa do ingresso na ordem moderna" (Idem, p. 222).

Em 1928, Macunaíma, de Mário de Andrade, irá imprimir uma visão crítica da nacionalidade, da identidade e da história da pátria. Ao contrário de Iracema (1865), a rapsódia não desempenha função conciliatória. O herói "sem nenhum caráter" funciona como uma alegoria da impossibilidade de determinar um caráter dominante que tipificasse o ser nacional. Também o discurso sobre a história não é mais ufano e tampouco promete um final feliz. "Perdida a Muiraquitã, a unidade é impossível. Restam os cacos e as ruínas de uma história a ser crítica e melancolicamente vivida", comenta Lucia Helena (1993, p. 526).

Na rapsódia de Mário, o discurso sobre a identidade cultural, sobre o nacional e sobre a história perde o cunho de unidade e totalidade e enfatiza a consciência das contradições internas e do subdesenvolvimento. A comunidade imaginada pelo autor modernista não é mais “objeto de uma pedagogia nacionalista que considera a nação uma totalidade estável e a identidade cultural uma essência fundadora resultante da conciliação de vencedores e vencidos" (Idem, p. 528). A partir daí, o herói, a identidade e a nação não são mais passíveis de representação sob a forma unificadora do símbolo, nem a narrativa tem mais função conciliatória. A narrativa de fundação se torna uma alegoria, do mesmo modo que a identidade cultural revela-se híbrida.

No artigo $O$ movimento modernista, Mário de Andrade ressalta um aspecto importante do período, que fez a nação ocupar um lugar central no pensamento modernista: a coletividade. Ele conta que apesar da consciência nacional aparecer em Gregório de Matos ou Castro Alves, essas manifestações eram episódicas como realidade do espírito. E em qualquer caso, sempre um individualismo (ANDRADE, 1974, p. 242), diferente do que ocorreu no romantismo e no modernismo.

Na década de 1930, a ficção brasileira não segue a trilha aberta por Oswald e Mário nos anos 20. No campo da pesquisa acadêmica, literatura e pensamento 
nacional caminham juntos produzindo ensaios histórico-sociológicos fundadores da nossa sociologia, como Casa Grande \& Senzala (1933), de Gilberto Freyre, Raízes do Brasil (1936), de Sérgio Buarque de Holanda, Evolução Política do Brasil (1933), de Caio Prado Júnior. Já os nossos ficcionistas se afastam da "problemática cultural que a modernização das grandes cidades havia colocado em pauta" e empreendem a reabilitação da narrativa regionalista. Com ela veio a ênfase nas questões socioeconômicas e a retomada do modelo narrativo típico do realismo do século XIX (FIGUEIREDO, 1994, p. 32).

A literatura produzida na década de 1930, em grande parte, apresenta sinais, ainda que tímidos, da compreensão por parte dos nossos intelectuais de que a nossa terra não era tão exuberante assim. Percebe-se, como destaca Antonio Candido, em Literatura e Subdesenvolvimento, que os solos eram pobres, as técnicas arcaicas e a população vivia uma "miséria pasmosa", mergulhada na “incultura paralisante" (Candido, 2006, p. 171)

Começa a predominar uma ideia pessimista com relação ao presente e problemática quanto ao futuro. Tal compreensão se dá em duas fases distintas: na primeira, em meados da década de 1930, há uma consciência amena do atraso nacional, uma vez que o Brasil ainda se considerava um país novo. Neste ideário ilustrado, a instrução traria automaticamente todos os benefícios e permitiriam "a humanização do homem e o progresso da sociedade". A literatura desse período tinha uma missão “combativa” (Idem, p. 176).

Num segundo momento, mais precisamente após a Segunda Guerra Mundial, começa a vigorar uma consciência catastrófica do atraso, aparecendo a noção de "país subdesenvolvido", onde predomina o analfabetismo, a debilidade cultural, a falta de meios de comunicação e difusão (editoras, bibliotecas, revistas, jornais), a dispersão e a fraqueza dos públicos disponíveis para a literatura, além da debilidade econômica e política e da dependência cultural (Idem, p. 173).

No caso brasileiro, grandes massas permanecem fora do alcance da literatura, mergulhadas numa "etapa folclórica de comunicação oral". Quando alfabetizadas e absorvidas pelo processo de urbanização, essas massas "passam para o domínio do rádio, da televisão, da história em quadrinhos, constituindo a base de uma cultura de massa" (p. 174). De modo que, saltamos sem escalas da 
“segregação aristocrática da era das oligarquias para a manipulação dirigida das massas, na era da propaganda e do imperialismo total" (Idem, 176).

Depois do modernismo, as manifestações do nacional na literatura se tornaram cada vez mais espaçadas e individuais. A partir de 1950, as questões nacionalistas, que antes da Guerra conotaram a militância de Direita, passam a bandeira esquerdizante e voltam a dominar. Segundo Alfredo Bosi, em sua História Concisa da Literatura Brasileira renova-se o gosto pela arte regional e popular, que no novo contexto sociopolítico reaparece com potência revolucionária (BOSI, 2006, p. 386-7). O autor afirma que os resultados artísticos desse período são irregulares, mas que alguns textos de Ariano Suassuna, Gianfrancesco Guarnieri, Augusto Boal e Dias Gomes se destacam na construção de um imaginário nacional.

Já o Brasil imaginado da década de 60 e 70 atribui as mazelas nacionais à subordinação ao imperialismo das nações centrais. O intelectual procura nesse momento "o povo". A ficção, como a de Antônio Callado, por exemplo, traça outro perfil à nação: "não há espírito conciliatório, mas de antagonismo; louva-se menos, denuncia-se mais; perde-se o tom idealista para ganhar um travo realista e combativo" (Germano, 2001). Em Quarup (1967), por exemplo, ao narrar a história de um padre que abandona o litoral e faz uma excursão ao centro geográfico brasileiro, a região do Xingu, Callado ajuda a compor o que se chama de Brasil - uma memória coletivamente compartilhada, procurando construir uma imagem-síntese do país (Ibidem). Porém neste romance, a "essência" da nação não é encontrada no passado histórico, como queriam os românticos, mas no interior longínquo do Brasil, "distante da costa atlântica e de seus contatos estrangeirizantes", onde "depois de muita peripécia” a expedição encontra um formigueiro (SCHWARZ, 1984, p. 33).

Na década de 80, Viva o povo brasileiro, de João Ubaldo Ribeiro, que narra três encarnações da "alminha brasileira", retoma os modos de construção da etnicidade fictícia que tornou possível a nação. Para Eneida Leal Cunha, em Literatura e Identidade, o autor desconstrói as ficções identitárias e as narrativas primordiais de fundação. O romance investe numa outra narrativa sobre o país e a identidade - diferente das tradições romântica de representação da nacionalidade e 
da antropofagia modernista -, ao tratar da violência que os rituais de dominação e a tradição dos discursos de identidade camuflaram e legitimaram (Cunha, 1998, p. 188).

A geração de escritores surgida no final do século XX, conforme propõe o escritor chileno Alberto Fuguet, participa de uma era em que as fronteiras encontram-se menos explícitas e as influências são tão globais que acabam criando um novo tipo de artista: "não o sujeito de algum lugar, mas ao contrário, o sujeito do aqui e agora" (FUGUET, 2005, p.102). Para o autor chileno, esta nova sensibilidade teria menos a ver com nacionalidade e mais a ver com empatia. As novas "almas globais", em vez de captarem a "essência" da aldeia para mostrar ao mundo, estariam buscando a "essência" do mundo como forma de revalorizar a própria aldeia (Idem, p.102-103).

Com isso, a configuração da economia capitalista no final do século XX, em seu estágio globalizado, estimula a construção de imaginários mais cosmopolitas, como pude analisar na minha dissertação de mestrado - Amores expressos: narrativas do não-pertencimento, igualmente orientada pelo professor Renato Cordeiro Gomes e defendida em 2010 - na qual abordei as crises de identidades nacionais, tendo como base três romances do projeto Amores expressos ${ }^{1}$, publicados até a ocasião: Cordilheira (2008), de Daniel Galera, que se passa em Buenos Aires, O filho da mãe (2009), de Bernardo Carvalho, cujo cenário é São Petersburgo, e Estive em Lisboa e lembrei de você (2009), de Luiz Ruffato, ambientado na capital portuguesa.

A dissertação procurou mostrar como a nova ordem mundial pôs em xeque a ideia de um Estado nacional soberano, homogêneo e unificado. Ao perder paulatinamente a autonomia política, econômica e cultural, as nações deixam de ser entendidas como uma forma de comunidade "natural" e passam mais e mais a serem vistas por seu caráter construído e muitas vezes autoritário e excludente. Neste sentido, o 'pseudo-conforto' da postura nacionalista de pertencer a um povo e a uma cultura é substituído pela possibilidade de novas identificações: sejam de

\footnotetext{
${ }^{1}$ O projeto, idealizado pelo escritor João Paulo Cuenca e pelo produtor Rodrigo Teixeira, consistia em enviar 17 autores nacionais por um mês a diversas cidades do mundo, com tudo pago, mais adiantamento de direitos autorais, para que escrevessem histórias de amor ambientadas naquelas cidades. Os romances seriam publicados posteriormente ou não a critério da editora Companhia das Letras.
} 
moradores da periferia, o movimento negro, a luta pelos direitos dos homossexuais ou outras formas de identificação que suplantem a nacionalidade.

A fixidez, o enraizamento, a ingenuidade e o patriotismo da era moderna dão lugar nos romances estudados à mobilidade espacial, à desterritorialização, a um ideário mais cosmopolita. Menos em Luiz Ruffato, um dos autores de Amores Expressos, nascido em Cataguases, na Zona da Mata mineira, em 1961. Embora tenha entrado na empreitada de ambientar o seu romance em Lisboa, levou consigo a problematização de uma nacionalidade em crise. A personagem principal, Serginho, ao contrário dos protagonistas Anita, de Cordilheira (2008) e Ruslan e Andrei, de $O$ filho da mãe (2009), é a única que ainda tem fortes vínculos com a terra natal. "De nada serve essa vida se a gente não pode nem mesmo aspirar ser enterrado no lugar próprio onde nasceu" (RUFFATO, 2009, p. 73), lamenta-se o protagonista.

Serginho sai de Cataguases, mas Cataguases não sai dele. Ele leva para Lisboa uma reflexão sobre os problemas do Brasil e dos países subdesenvolvidos, em sua maioria ex-colônias. Serginho é um desprivilegiado do mundo, como "tantos pobres-diabos africanos, árabes, indianos, babel de raças e cores", recrutados pela metrópole hostil para fazer serviços menores de garçom, pedreiro, prostituta, faxineira, sem qualquer garantia trabalhista, vivendo à margem da cidadania, "esgoelando, chorando", se espremendo na mesma cabine telefônica para dar e receber notícias de parentes deixados para trás (Idem, p. 73).

Serginho não fala o inglês desejado para atender os clientes estrangeiros do restaurante em que trabalha, não tem qualificação profissional, não é ninguém. "Nós estamos lascados Serginho, aqui em Portugal não somos nada, 'Nem nome temos', somos os brasileiros, 'e o que a gente é no Brasil?' nada também, somos os outros" (Idem, p. 78), diz um amigo do protagonista. Ao contrário das demais personagens do projeto, ele sofre com o rompimento com a sua cultura e história de seu país: "só boto os pés de novo dentro de um [avião] na hora de voltar para o Brasil, depois, finco eles no chão e não saio nunca mais" (RUFFATO, 2009, p. 41), promete a personagem.

A constatação deste desconforto de Ruffato em relação à terra natal, um misto de afeto e crítica fervorosa à história pátria, me fez voltar os olhos para 
outros títulos publicados pelo autor. Ao tomar contato com sua obra, pude perceber que desde 1998, quando escreveu História de remorsos e rancores, seu primeiro livro a ser publicado por uma editora com maior potencial de distribuição, a Boitempo Editorial, o autor vem se dedicando a representar um lado da nação historicamente excluído: operários, lavadeiras, costureiras, prostitutas, pipoqueiros, tecendo uma interpretação contundente da realidade nacional, fazendo eco ao cânone literário que se propõe ler o Brasil e intervindo no imaginário nacional.

A partir da série Inferno provisório, também de Luiz Ruffato, composta de cinco volumes publicados pela editora Record - Mamma, son tanto felice (2005), O mundo inimigo (2005), Vista parcial a noite (2006), $O$ livro das impossibilidades (2008) e Domingos sem Deus (2011) -, a proposta desta tese é discutir como o autor se propõe narrar a nação, em tempos em que as ideias de singularidade e autenticidade há muito já fazem papel de velharia e provincianismo (SCHWARZ, 1987, p. 34). O que significa escrever Inferno provisório neste contexto e quais as ferramentas utilizadas por Ruffato para não cair na armadilha de projetar uma dimensão política na forma de "alegoria nacional"? Como evitar retomar "como um gongo" a questão da nacionalidade, obsessão que o crítico americano Fréderic Jamenson ${ }^{2}$ já apontara como peculiar à literatura do "terceiro mundo"?

O capítulo 2, "Como pensar a nação hoje", faz uma revisão de como os críticos contemporâneos encaram a reflexão sobre nação e nacionalidade na literatura brasileira no século XXI e o deslizamento desta questão para outros meios como o cinema, a TV e o cancioneiro. E ainda que ferramentas os autores contemporâneos que se propõem a narrar a nação em pleno século XXI utilizam para dar forma a esse tipo de comunidade imaginada. Vemos surgir neste capítulo a implosão de conceitos de soberania, homogeneidade, progresso, história linear,

\footnotetext{
${ }^{2}$ No polêmico ensaio "A literatura do terceiro mundo na era do capital multinacional", de 1986, o crítico americano afirma categoricamente que os textos do terceiro mundo necessariamente projetam uma dimensão política na forma de alegoria nacional. Em contundente resposta a este artigo, o crítico indiano Aijaz Ahmad rebate um a um os argumentos de Jameson, dizendo, sobretudo, que não existe "uma literatura de terceiro mundo" que possa ser um objeto de "conhecimento teórico internamente coerente" (1988, p 158-9) e que a generalização do crítico americano não passa de um "reducionismo de todo positivista" (Ibidem).
} 
evolutiva e causal e a alvorada da "história dos vencidos", da fragmentação e da diferença na intenção de dar conta desse novo cenário.

O subcapítulo "Do paraíso ao inferno" desenvolve um histórico da concepção da nossa nacionalidade, nascida sob égide do mito do paraíso, passando no início do século XX a ser pensada sobre novos alicerces: a violência colonial, a escravidão, a república excludente, dentre outras questões. O capítulo se dedica ainda a, a partir do polêmico discurso proferido por Luiz Ruffato na Feira Internacional do Livro em Frankfurt, em 2013, inserir o autor nessa tradição de denúncia das injustiças sociais, a invisibilidade de uma classe social renegada tanto pelo discurso oficial quanto pela própria literatura e os efeitos que esse descaso provoca na sociedade, onde o semelhante torna-se inimigo. Um projeto literário que se dispõe a colocar o dedo na ferida e chama à atenção para a desagregação nacional. Na crença de que na globalização as fronteiras caem para as pessoas, vemos que de fato elas caem para o capital e as mercadorias, de modo que o enfraquecimento do estado nacional faz com que nos tornemos consumidores do século XXI e cidadãos do século XVIII.

O capítulo 3 composto pelos tópicos "Como chegamos até aqui", que analisa os três primeiros volumes de Inferno provisório e "O Brasil urbano", que comenta os volumes 4 e 5, - retira da coletânea Inferno provisório, audacioso projeto que se propõe revisitar as últimas décadas da história nacional, subsídios para se pensar o país, mostrando que passamos da roça para a periferia decadente sem escalas. Imagens da industrialização e urbanização desenfreadas, o abandono do campo, a manutenção da velha ordem patriarcal, a modernização excludente, a precariedade da saúde, o analfabetismo, a dispersão das famílias, racismo, preconceito religioso entre outras questões intimamente ligadas à realidade nacional, se entrelaçam, se repetem, levando de um romance ao outro num caminho sem direção fixa.

O quarto capítulo se dedica a analisar a coletânea, mostrando como a saga representa pessoas, lugares e reputações que ajudam a compor uma imagem arruinada da nação. A segunda parte, "Fora da Ordem e do progresso", examina o exercício do autor de romper com os modelos realísticos, linear e causal (tradicionalmente utilizado pela burguesia do século XIX) para fazer aflorar uma 
linguagem lacunar, fragmentada, cujo propósito seria acentuar o estado de abandono e precariedade da vida dessas personagens excluídas da história oficial e que Ruffato, através de sua obra, procura inserir no mapa.

Se a saga propõe uma interpretação do país em rede - avessa à linearidade a estrutura dessa tese é também cumulativa. É interessante perceber que, apesar de toda a crítica tecida por Luiz Ruffato à sociedade brasileira, que se esgarça rumo aos grandes centros urbanos em busca de uma entrada triunfal na modernidade nunca alcançada, a saga funciona como um livro de registro de um Brasil que se vai esquecendo e se deixando para trás. O grito agoniado e fragmentado do autor mostra que a força motriz do país, ou seja, a massa trabalhadora, foge de sua própria história, seja por considerá-la irremediável, seja por que se alimenta da ilusão de ser contemplada pelas benesses da globalização. Sendo assim, Luiz Ruffato articula historicamente o passado não "como ele de fato foi", mas como propõe Walter Benjamin, "apropriando-se de uma reminiscência, tal como ela relampeja no momento de um perigo" (1994, p. 224). Imbuído de esperanças, o autor mineiro resgata uma memória coletiva na certeza de que proclamar a nossa singularidade é uma forma de resistir à tentativa autoritária de aplainar as diferenças ${ }^{3}$.

\footnotetext{
${ }^{3}$ http://www.estadao.com.br/noticias/arteelazer,leia-a-integra-do-discurso-de-luiz-ruffato-naabertura-da-feira-do-livro-de-frankfurt,1083463,0.htm. Acesso em 02/04/2014.
} 


\section{Como pensar a nação hoje}

A redemocratização da vida nacional, de acordo com Beatriz Resende, possibilita que a geração de ficcionistas brasileiros surgida a partir da segunda metade da década de 1990 fique livre de qualquer necessidade de denúncia ou exaltação nacional reapropriada (2008, p. 24). Essa geração coloca a literatura em sintonia com os tempos pós-modernos, tratando de novas subjetividades, da tensão entre o local e o global, da desterritorialização e do fim da barreira entre a alta cultura e a cultura de massa. É uma literatura marcada pela multiplicidade de temas, formatos, linguagens e suportes.

Vera Follain de Figueiredo, por sua vez, crê que os rumos tomados pela economia capitalista no final do século XX, tendem a tornar a nação, tal como concebida pela modernidade, uma "ficção desnecessária" (1999, p. 73). Giovanna Dealtry corrobora essas visões das narrativas contemporâneas, que, para ela, evidenciam o surgimento de sujeitos "sem identidade fixa" e que, cada vez menos, estabelecem vínculos de pertencimento exclusivos com a nação de origem (2007, p. 175).

Tais diagnósticos nos levam a crer que a nação, que ocupara um lugar central na literatura romântica e modernista, contribuindo para a consolidação do imaginário nacional, sai de cena abrindo caminho para imaginários cada vez mais cosmopolitas. Assistimos ao que Vera Follain de Figueiredo chama de "desinvenção da nação", desencadeada pelo atual estágio do capitalismo, a globalização (Idem, p. 73). Estágio este em que, além de nos relacionarmos efetivamente com muitas sociedades, podemos situar a nossa fantasia em múltiplos cenários ao mesmo tempo.

O cinema brasileiro contemporâneo estaria, ainda de acordo com Vera Follain, retomando a função assumida na década de 1960 por Glauber Rocha com Deus e o diabo na terra do sol (1963) de reorganizar o imaginário nacional brasileiro. Central do Brasil (1999) e Terra estrangeira (1994), de Walter Salles Jr. trabalham "o sentimento de orfandade decorrente do fato de a mãe-pátria querer sair do cenário antes de o filho atingir a maioridade” (1999, p. 73). Já Renato Cordeiro Gomes vê na TV um projeto de reatualização das questões românticas e modernistas. Para ele, algumas novelas e minisséries divulgam 
conteúdos referencializados na cultura brasileira, nos quais se plasmariam a identidade cultural do Brasil, tais como Hoje é dia de Maria, dirigida por Luiz Fernando Carvalho, Via Brasil (Globo News), Expedições, Impressões do Brasil e Brasilianas.org (TV Brasil). Além disso, certa filmografia nacional estaria retrabalhando essa herança na forma de 'resíduo', através de documentários de Silvio Tendler e Eduardo Coutinho, além do recente $O$ som ao redor (2012), de Kleber Mendonça Filho, ajudando a compor uma 'aparição fantasmal' da nação (GOMES, 2014, p. 47).

Diante desse contexto, encontrar um livro de ficção que se dedique a refletir sobre a história nacional ou simplesmente narrar o desenrolar de seus dias soa no mínimo fora de moda. Mas a literatura brasileira em sua era da "multiplicidade" ainda guarda algum espaço para esse tipo de abordagem, indo na contramão de um ideário cosmopolita. Leite derramado (2009), de Chico Buarque, Heranças (2008), de Silviano Santiago, O Brasil (2013), de Mino Carta e a série Inferno provisório (2005-2011), de Luiz Ruffato, são apenas alguns exemplos que corroboram este pensamento.

O tom conciliatório, a noção de identidade fixa, a ideia da literatura como dever patriótico, contribuição para o progresso e cimento ideológico capaz de promover a coesão nacional, comuns ao período romântico, saem de cena. A tendência ao esquecimento e apagamento de uma realidade nacional indesejada, marca registrada do romantismo, saem também.

Se as narrativas românticas lançaram a semente da ideologia da conciliação pacífica de interesses divergentes, ocultando a violência da conquista colonial, a literatura contemporânea irá chamar a atenção justamente para a falta de coesão nacional e para nossas contradições internas, ressaltando o caráter forjado da construção nacional. $\mathrm{O}$ apagamento da diversidade cultural, o esquecimento do passado histórico indesejado, o discurso pedagógico e a legitimação da versão oficial da História, algumas das características mais problemáticas do Romantismo, se tornaram definitivamente obsoletas.

O historiador Ernest Renan, em seu seminal ensaio $O$ que é uma nação (1882), já havia especulado que a evolução dos estudos históricos representaria um perigo para a nacionalidade, uma vez que a unidade nacional é sempre feita 
brutalmente. "Na verdade, a investigação histórica traz à luz fatos de violência ocorridos na origem de todas as formações políticas" (1997, p. 14), avalia. De fato, a evolução de nossos estudos históricos e sociais e a tomada de consciência acerca de nosso atraso e subdesenvolvimento já não permite que nossos criadores imaginem o Brasil como paraíso terrestre.

Os autores contemporâneos recebem como herança de um lado a noção catastrófica da realidade nacional, e de outro uma implosão da ideia de nação desencadeado pela globalização. Estímulos vindos de diversas partes do planeta "tendem a tornar a nação, tal como concebida pela modernidade, uma ficção desnecessária", retomando a frase de Vera Follain de Figueiredo. Mas a frase em questão, nos leva a refletir a respeito de seu objeto. Trata-se de uma ficção desnecessária para quem? Se voltarmos ao ensaio da autora, percebemos que a nação moderna é desnecessária ao capitalismo em seu atual estágio. Ainda assim, teria a nação perdido o seu potencial narrativo? Duas questões precisam ser colocadas: a ideia de nação "moderna" - homogênea e unificada - já não existe e a reflexão sobre a nação contemporânea não atende à demanda do capitalismo. Continua, porém, como necessidade de alguns autores, que ainda acreditam no poder da literatura para questionar as estruturas de poder dominantes.

Com isso, ao que parece, a nação já não é mais narrada à maneira moderna, buscando algum tipo de síntese na forma de símbolo como em Iracema (1865), de José de Alencar, ou de alegoria como em Macunaíma (1928), de Mário de Andrade. Embora existam brechas para o resgate da narrativa da nação, nos quais os recursos legados pela tradição modernista e de vanguarda "constituem um estoque, ou um arquivo, pronto para ser manipulado", não há, no entanto, de acordo com Renato Cordeiro Gomes "um programa ou um projeto orientador" nem "palavra de ordem ou dogma autoritário" a serem seguidos (GOMES, 2007, p. 11). O que vemos é um constante processo de ressignificação e reinterpretação atualizada da nação.

A narrativa da nação ressurge no contexto contemporâneo sob o caráter residual, no sentido teorizado por Raymond Williams, em Marxismo e literatura. De acordo com o pensador inglês, um processo cultural apresenta características dominantes, emergentes e residuais. Embora formado no passado, o residual "está 
ativo no processo cultural, não só como elemento do passado, mas como elemento efetivo do presente" (1979, p. 125). Os elementos residuais parecem não ter significação porque representam aspectos sócio-culturais que "a cultura dominante negligencia, subvaloriza, opõe, reprime ou nem mesmo pode reconhecer" (1979, p. 125).

Neste sentido, ainda que a globalização em seu caráter dominante deixe cambaleante a ideia de pertencimento a uma comunidade imaginada, soberana e limitada, esse tipo de formação ainda não se extinguiu, oferecendo aos artistas bom e largo manancial para interpretação e imaginação. Em vez de ser pensada como uma forma de comunidade "natural", no entanto, ela passa mais e mais a ser vista como fruto de contingências históricas ultrapassadas e injustas.

Ao mesmo tempo, como é possível narrar em pleno século XXI esse tipo de formação social que é a nação, surgida no século XVIII, XIX? Como se sabe, as vanguardas europeias e o modernismo brasileiro já haviam posto em xeque as formas de representação tradicionais na primeira metade do século XX. A Segunda Guerra Mundial por sua vez pôs novamente na berlinda conceitos chaves como razão, ciência, progresso, história linear, evolutiva e causal, que moveram a história do Ocidente. A revelação mundial dos campos de extermínio nazistas e a explosão das bombas atômicas de Hiroshima e Nagasaki, em 1945, são acontecimentos que modificaram o pensamento e o imaginário processado até então. O poder total concedido ao progresso tornou possível a destruição da essência humana e a extinção do homo sapiens. Auschwitz minou a crença na evolução da humanidade, e Hiroshima provou que a ciência não fez aumentar apenas a qualidade de vida, como também a qualidade de morte (GUINSBURG, 2008, p. 25 - 27).

Com isso, a visão oitocentista da história, teleológica, concebida por Hegel e Croce, caracterizada pelo esforço de constituir uma ciência realística do homem, da sociedade e da cultura, baseada na clareza e na crença no progresso, perdeu terreno na pós-modernidade para uma história paralela, a história dos vencidos, a anti-história. Deu-se uma implosão das categorias pelas quais o mundo havia sido pensado e, com isto, novas formas de representação capazes de dar conta da nova realidade passaram a ser experimentadas. A realidade danificada pela experiência 
das catástrofes do século $\mathrm{XX}$, impossibilita o próprio ato de narrar e a representação da totalidade. Restaria assim, segundo Adorno, apenas o fragmento como recurso formal antagônico, expressando a negatividade do progresso histórico (In: PELLEGRINI, 2012, p. 15).

Silviano Santiago, no ensaio Leitor e cidadania, ao falar da desconstrução dos conceitos nacional e universal, complementa o pensamento a que aqui se quer chegar, da impossibilidade de se narrar a nação tal como o fizeram nossos escritores românticos e modernistas. De acordo com o autor, o primeiro termo, nacional, é questionado pelos novos movimentos sociais, que se unem em busca de uma política de identidade para grupos minoritários excluídos no processo de consolidação da nação. Tais grupos julgam que a ideia e a prática do nacional no Ocidente teriam sido arquitetadas pelo poder dominante, através de divisões sociais e políticas internas, calculadas, que rejeitavam determinados segmentos sociais da nacionalidade (mulheres, índios, negros, homossexuais, grupos religiosos etc.) para a margem da cidadania política (SANTIAGO, 2004, p.170).

Já o termo 'universal' estaria sendo questionado por estudiosos e ativistas políticos que veem embutida na constituição do próprio termo uma "decidida homogeneização do mundo pelos padrões colonizadores da civilização europeia". Tal universalidade apontava um caminho único a ser seguido pela humanidade para se atingir o progresso. Para muitos antropólogos, essa universalidade etnocêntrica estaria suplantando e excluindo as culturas alheias, em nome de um progresso que seria igual para todos, e que, hoje se sabe, é uma falácia (Idem, p. 172).

Santiago conclui, então, que como decorrência da desconstrução desses dois conceitos, nacional e universal, o modo de representar o real é a fragmentação. "Processos estéticos e políticos descontínuos e múltiplos, plurais, coexistem" produzindo nos leitores incômodo e desconforto. Essa fragmentação transparece num discurso ficcional, que perdeu duas certezas: a primeira é a de representar o nacional como identidade, 
o que, no otimismo reinante na década de 1920, foi genialmente feito pelos grandes escritores modernistas, haja vista, por exemplo, as grandes alegorias do Brasil moderno que são o romance Macunaíma, de Mário de Andrade e a coletânea de poemas Pau-Brasil, de Oswald de Andrade (SANTIAGO, 2004, p.174).

A desconfiança do artista em dar significado a identidades que possam ser únicas e compactas - mas que não são - não satisfazem o leitor de nossos dias, já desnorteado com acontecimentos terríveis propagados pela mídia eletrônica (Ibidem). A segunda certeza perdida com tal fragmentação é a de poder narrar uma história com princípio, meio e fim, cronologicamente, como fazia o romance burguês do século XIX.

Perdidas as antigas certezas da modernidade, a representação das "comunidades imaginadas" que se deram de maneira compulsiva, através de narrativas que, nas palavras de Homi Bhabha, estiveram permanentemente a reconstruí-las, movidas pelo desejo de uma potência simbólica unificadora (In: CUNHA, 1998, p. 182), parece dar sinais de esgotamento.

Assiste-se ao deslocamento do Estado-nação como centro de um sistema de significação que marcou, desde o século XIX, a base geopolítica da cultura. A nova significação do mundo não é mais derivável do Estado-nação. Os modos de usar a nação, como rastro residual de uma passagem que não existe mais, exige então uma reelaboração performática da nação. Os conceitos de pureza e unidade são substituídos pelos de culturas híbridas e fragmentadas. O tempo homogêneo das comunidades imaginadas, difundidas pelos romances e jornais, caem por terra, dando lugar à ideia de tempo desigual, que corresponde às diferentes experiências dos distintos grupos sociais. As noções de entre-lugar (Silviano Santiago), das diferenças internas, de alteridade e das diferenças fazem frente à noção de semelhança.

"Hoje a diferença cultural intervém para transformar o cenário da articulação, reorientando o conhecimento através da perspectiva significante do ‘outro’ que resiste à totalização”, observa Renato Cordeiro Gomes, que entende a nação contemporânea ao mesmo tempo como "uma casa assassinada cujos 
vestígios e memórias enfrentamos enquanto espectros que assustam”, mas também, contraditoriamente, como uma ideologia que acalenta ${ }^{4}$.

A consciência da miopia contida nas ideias totalizantes faz com que autores contemporâneos, dentre eles Luiz Ruffato, busquem formas de representação da realidade mais inspiradas nas ideias de história plural, tempo heterogêneo, hibridismo, performance, simultaneidade e representação das minorias. A linguagem eleita pelos contemporâneos para a representação do real passa a ser a fragmentação, para dar conta de como a implosão daquela visão das coisas rompeu, despedaçou, a antiga unidade ideal de nação.

\subsection{Do paraíso ao inferno}

No ensaio "Nação imaginária: memória, mitos e heróis", o historiador José Murilo de Carvalho lembra que o primeiro mito brasileiro registrado data de 1500, na carta de Pero Vaz de Caminha ao rei de Portugal. De lá para cá, “a visão edênica da nova terra foi reiterada muitas e muitas vezes pelos portugueses, brasileiros e estrangeiros, até se tornar um importante ingrediente do imaginário nacional. Tornou-se o mito edênico brasileiro", diz o autor. (CARVALHO, 2003, p. 402). Assim, o Brasil durante séculos foi narrado tal qual um paraíso terrestre como no período romântico, que reciclou esse mito em poemas como Canção do Exílio (1843), de Gonçalves Dias; no livro Porque me ufano do meu país (1900), de Affonso Celso; e, por exemplo, na letra do hino nacional (1909), de autoria de Joaquim Osório Duque Estrada.

O mito edênico incluiria o orgulho pelas belezas e riquezas do país; uma noção de paraíso como um presente a ser aproveitado e não construído; e que fosse como um jardim aberto a todos (Idem, p. 413). Esse imaginário ecoa até hoje, como comprovam os sucessos de músicas como País tropical (1969), de Jorge Benjor, e Aquarela brasileira, samba-enredo composto por Silas de Oliveira para o desfile do Império Serrano, de 1964, reeditado no carnaval de 2004. As

\footnotetext{
${ }^{4}$ http://oglobo.globo.com/blogs/prosa/posts/2011/05/09/resenha-de-nacoes-literarias-de-wanderde-melo-miranda-378889.asp. Acesso em 2/04/2014.
} 
duas músicas exaltam um país que seria abençoado por Deus e de natureza estonteante. Uma maravilha de cenário, onde tudo é belo.

Ainda de acordo com José Murilo, pesquisas de opinião pública, feitas em 1996, revelam que $60 \%$ dos brasileiros ainda tinham muito orgulho de seu país, sendo a principal razão a exuberante natureza. "As respostas repetiam as mesmas expressões desde Caminha: um clima agradável e saudável, grandes florestas e rios, lindos céus e lindas praias, terra fértil e abundância de recursos animais, vegetais e minerais" (Idem, p.403). Neste caso, a história nacional aparece como algo muito estranho aos brasileiros, como se eles não tivessem nada a ver com ela.

José Murilo alerta, no entanto, para o contraste entre esse imaginário edênico e uma realidade nacional dramática, pois, exceto por suas dimensões geográficas, pelo tamanho da população e pelo futebol, o país se destaca internacionalmente por sua desalentadora estatística de pobreza, analfabetismo e péssimos índices de desigualdade social e ainda pela crescente violência e brutalidade policial. "Um fenômeno desanimador para um país que se vê como cordial e pacífico" (CARVALHO, 2003, p. 414).

O argumento de Carvalho é retomado por Luiz Ruffato no discurso proferido na Feira Internacional do Livro em Frankfurt, realizada em outubro de 2013, no qual o autor mineiro aborda os nossos problemas histórico-sociais sem eufemismos. No discurso, que teve por aqui grande repercussão, o autor denuncia o genocídio dos índios, a exploração e o abandono do escravo negro e a falsa “democracia racial", uma vez que o fato de a nossa população ser mestiça se deve em grande parte ao estupro das nativas e negras por parte dos colonizadores brancos.

Ruffato chama a atenção ainda para os problemas da concentração de renda, a impunidade, o alto índice de homicídios, o machismo, a violência doméstica, a homofobia e a precariedade do sistema educacional, este como um dos mecanismos mais eficazes de manutenção do abismo entre ricos e pobres. Para José Miguel Wisnik, o discurso de Ruffato teria sido um "strip-tease nacional em meio a protocolos de uma cerimônia internacional de alto coturno". Ele teria posto "a nu de maneira enfática a desigualdade social e racial, as taxas e as formas de violência no passado e no presente, os níveis de analfabetismo literal e funcional, 
as precárias condições de vida de grande parte da população brasileira” (O Globo, $12 / 10 / 2013)$.

Embora Ruffato reconheça que com a estabilidade política e econômica dos últimos anos, acumulamos algumas conquistas sociais, para ele, infelizmente, apesar de todos os esforços, o legado de 500 anos de desmandos ainda está longe de ser sanado. "Continuamos a ser um país onde moradia, educação, saúde,

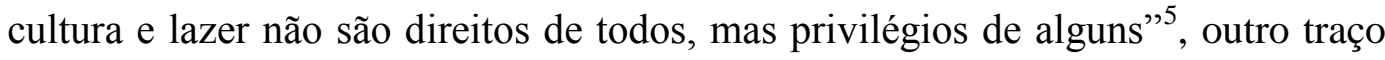
da nossa cultura.

A imagem do Brasil é, para ele, calcada num paradoxo: oscila de mito do jardim do éden e da crença de que somos o país do futuro à trágica consciência de país atrasado e injusto. De "região exótica, de praias paradisíacas, florestas edênicas, carnaval, capoeira e futebol", a lugar "execrável, de violência urbana, exploração da prostituição infantil, desrespeito aos direitos humanos e desdém pela natureza"6. Ora somos festejados como um dos países melhor preparados para ocupar o lugar de potência mundial, por nossos "amplos recursos naturais, agricultura, pecuária e indústria diversificadas"; ora estamos destinados a ocupar um "eterno papel acessório, de fornecedor de matéria-prima e produtos fabricados com mão-de-obra barata". Isso porque somos a sétima economia do planeta, mas permanecemos em terceiro lugar entre os mais desiguais de todos.

Para ele, a história do Brasil vem sendo alicerçada quase que exclusivamente pela negação explícita do outro, por meio da violência e da indiferença. Essa negação do outro, ou seja, daquilo que nos constitui, a nossa alteridade, faz com que sejamos ignorantes de nós mesmos. Embora a logomarca do governo Dilma Roussef pregue que o Brasil é "um país de todos”, Ruffato procura mostrar tanto no seu discurso ensaístico, quanto através de sua obra, que existe um grande contingente de brasileiros habituados a cumprir deveres sem nunca ter seus direitos garantidos e por isso sucumbidos "numa estranha sensação de não-pertencimento", migrando da roça para a pequena cidade, da pequena cidade para os grandes centros, para muitas vezes voltar à cidade natal sem nunca encontrar o que se busca, uma vida mais digna. Enquanto o discurso oficial negar

\footnotetext{
${ }^{5}$ Discurso de Frankfurt: http://www.estadao.com.br/noticias/arteelazer,leia-a-integra-do-discursode-luiz-ruffato-na-abertura-da-feira-do-livro-de-frankfurt,1083463,0.htm (acesso em 18/12/2013). ${ }^{6}$ Idem
} 
a própria história, acumularemos ódios: "o semelhante torna-se o inimigo", acredita o autor ${ }^{7}$.

Para Wisnik, existe ainda no Brasil uma outra contradição para além da oposição de praias, carnaval, capoeira e futebol" x "injustiça social", que é a capacidade de "reverter muitas vezes a violência em seu contrário". Mas qual seria esse contrário? Um dos caminhos possíveis seria talvez a transformação de um quadro de violência social em fonte de inspiração para a produção de cultura e arte, por exemplo, um dos alicerces da obra literária de Luiz Ruffato. Heloísa Buarque de Hollanda, pesquisadora especialista nas novas subjetividades produzidas nas periferias dos grandes centros urbanos, diz considerar a cultura hip hop "uma das formas mais criativas e eficazes dos vários usos possíveis da cultura como recurso inclusivo, de geração de renda, de promoção do conhecimento, de estímulo à educação formal e portanto de autoestima" (2014, p. 31).

Embora o discurso de Ruffato em Frankfurt tenha pintado um quadro sombrio, o recado é otimista como comenta Alexandre Vidal Porto, no artigo "O país dos pipoqueiros": "apesar de todas as mazelas, o Brasil consegue transformar filhos de lavadeiras analfabetas em escritores cujos discursos movimentam a maior feira de livros do mundo", (Folha de S. Paulo, 12/10/2013).

Mas há quem tenha ficado bastante incomodado com o discurso do autor. Rodrigo Constantino, articulista da revista Veja, por exemplo, sentiu falta de um Brasil "literário" e "mágico", acusando Ruffato de fazer "proselitismo". Para Constantino, artistas não deveriam falar de política e sim de temas atemporais e universais. Critica, por fim, a utopia de o escritor mineiro acreditar no poder transformador da literatura. "Confesso preferir escritores como Mário Vargas Llosa, que querem contar uma boa história, fazer arte, literatura e não 'mudar o

\footnotetext{
${ }^{7} \mathrm{O}$ ano de 2013 foi marcado por manifestações de rua, que se espalharam rapidamente pelo país. Convocada por meio das redes sociais, a população foi às ruas para protestar contra o aumento sistemático das passagens de ônibus sem que houvesse melhoria nos serviços de transporte público. De início pacíficas, as manifestações foram se tornando extremamente violentas em função da reação desproporcional da polícia militar que agredia a população com bombas de gás lacrimogênio e gás de pimenta. Passados seis meses de protestos, o resultado foi que as passagens aumentaram à revelia da população, um repórter cinematográfico que registrava uma manifestação foi atingido por uma bomba caseira e dois manifestantes foram responsabilizados pelo acidente e estão presos. Tal episódio exemplifica bem a frase de Ruffato de que os semelhantes (repórter cinematográfico / manifestantes) tornam-se inimigos.
} 
mundo'. Proselitismo não é arte, política escancarada não é literatura. E tenho dito!"8, esbraveja.

Em ensaio publicado recentemente sobre os caminhos da escrita literária no Brasil, Beatriz Rezende traz à tona um conceito de Jacques Rancière caro à compreensão da política em Ruffato. Para aquele filósofo, a política da literatura não é a política dos escritores, nem como eles representam as estruturas sociais ou os movimentos políticos. "A expressão política da literatura quer dizer que a literatura faz política enquanto literatura, isto é, supõe que há uma ligação essencial entre a política como forma específica de prática coletiva e a literatura como prática definida da arte de escrever" (2014, p. 14-15).

Silviano Santiago, por sua vez, acredita, como afirma no ensaio Uma literatura anfíbia (SANTIAGO, 2003, p. 73), que ainda hoje arte e política andam de mãos dadas no Brasil. "Caso a educação não tivesse sido privilégio de poucos desde os tempos coloniais, talvez tivéssemos podido escrever de outra maneira o panorama da literatura brasileira contemporânea". No lugar de a literatura ser usada ut doceat (para educar), ela poderia se ater a apenas dois princípios da estética: ut delectet e ut moveat (para deleitar e comover), que segundo o autor não fazem parte da nossa realidade.

Voltando ao articulista da Folha, Alexandre Vidal, ele compreende que Ruffato tenha reforçado alguns clichês indesejáveis e persistentes do país, mas acredita que "idealizar o Brasil e esconder seus problemas no armário não é justo com nossos analfabetos - escritores, músicos e médicos - que ainda empurram carrinhos de pipoca pelo país afora como o próprio Ruffato empurrou”. Nesse quadro, "o Brasil literário é tragédia e o que há de mágico é sobreviver"”.

Mas é preciso fazer aqui uma distinção entre o discurso político de Ruffato, aquele presente nas palestras, entrevistas, ensaios, e o discurso literário do autor. O primeiro é um exercício sóbrio e objetivo de contestar a realidade social. O segundo, ainda que seja político também, é um exercício sombrio de investigação

\footnotetext{
${ }^{8}$ http://veja.abril.com.br/blog/rodrigo-constantino/cultura/o-discurso-de-luiz-ruffato-em-frankfurt/. Acesso em 13/11/2013.

9 “O país dos pipoqueiros", Folha de S. Paulo, 12/10/2013).
} 
das singularidades nacionais através de uma linguagem fragmentada, angustiada, obscura e lacunar.

Embora ele alegue no discurso político que "proclamar a nossa singularidade é uma forma de resistir à mediocrização, à tentativa de aplainar autoritariamente as diferenças culturais" (RUFFATO, 2008, p. 323), que reflete o seu pensamento de que as fronteiras derrubadas pela globalização servem apenas para mercadorias e não para pessoas, o seu discurso ficcional não assume uma postura "essencialista" ou "patriótica" em oposição à "ameaçadora" homogeneização cultural.

Como já alertara Roberto Schwarz, em Nacional por subtração, ainda na década de 70, quando a cultura estrangeira começou a entrar no país através dos veículos de comunicação de massa, a defesa da nacionalidade brasileira já parecia ser um tema arcaico e provinciano. Pela primeira vez, "entra em circulação o sentimento de que a defesa das singularidades nacionais contra a uniformização imperialista é um tópico vazio" (Schwarz, 1984, p. 33). Ou, como pontua Silviano Santiago no seminal ensaio "O entre-lugar do discurso latino americano", a América Latina parece perceber que não pode mais fechar as suas portas à invasão estrangeira e “tampouco reencontrar sua condição de 'paraíso', de isolamento, de inocência” (SANTIAGO, 2000, p. 16).

Um olhar atento sobre a obra ficcional de Ruffato permite perceber que a defesa das nossas singularidades, a que o autor se refere, não é em oposição a culturas estrangeiras. Trata-se de um exercício de representar as nossas singularidades - exclusão social, violência doméstica, racismo, analfabetismo, alcoolismo e toda uma atmosfera de abandono e esquecimento nos modos em que eles se dão no Brasil - fugindo das formas hegemônicas de representação da nossa realidade, historicamente legitimadas, e que frequentemente caem nos clichês e estereótipos "carnaval, praias paradisíacas e futebol” x "injustiça social”. Ruffato consegue fugir à mediocrização da homogeneização cultural não apenas por cantar ou meramente decantar as nossas singularidades, mas porque traz para a sua literatura a inquietação e o desconforto de narrar o universo dos despossuídos.

No lugar de privilegiar o relato transparente, objetivo e fotográfico tão comuns às narrativas documentais ou de cair na armadilha historicista de 
preencher lacunas através do registro realista - cuja visão retrospectiva do passado visa a alcançar a unidade e a totalidade do mundo -, Ruffato lança mão do humor, do fragmento e da ambiguidade compondo um discurso inovador e instigante no qual a singularidade estética triunfa sobre a singularidade nacional. Além disso, sua obra ficcional consegue ser um instrumento de resistência à estandardização cultural sem cair num discurso panfletário ou antiglobalizante.

No ensaio Até aqui, tudo bem! (Como e por que sou romancista - versão século 21), o autor reforça o que costuma dizer em suas entrevistas, que o seu esforço como escritor é representar os "sem voz, sem nome" (2008, p. 318), ou seja, o universo "do trabalhador urbano, os sonhos e pesadelos da classe média baixa, esse recorte social indefinido, com todos os seus preconceitos e toda a sua tragédia" (Idem, p. 319).

Além de ser um universo que lhe é familiar (pois o autor é filho de um pipoqueiro e de uma lavadeira, e foi também operário da indústria têxtil, pipoqueiro e atendente de armarinho), ao pesquisar a história da literatura brasileira, Ruffato verifica quão poucos escritores se dedicaram a representar o proletariado $^{10}$. Ele acredita que a escassez de representação literária desta classe se deve à sua falta de glamour, ao contrário do malandro ou do bandido, personagens sempre presentes na ficção nacional, que são representados como “desestabilizadores da ordem social” (Idem, p. 319-320).

No ensaio Literatura brasileira contemporânea: um território em disputa, Regina Dalcastàgne, professora titular da Universidade de Brasília, atesta este raciocínio de Ruffato, chamando a atenção para a ausência quase absoluta de representantes das classes populares na literatura brasileira, tanto no campo dos produtores literários (autores), quanto no que diz respeito a enredos, cenários e personagens. Trata-se, segundo a pesquisadora, de uma "negação do direito de

${ }^{10}$ Ainda que não tenha uma representação intensa, não se pode ignorar que alguns romances, em geral da década de 1930, quando o Comunismo estava ganhando adeptos no país, representaram sim o cotidiano dos trabalhadores urbanos: Gororoba (1931), de Lauro Palhano, pseudônimo de Juvêncio Lopes da Silva, relatava a história de um técnico da construção da Estrada de Ferro Madeira-Mamoré; Parque industrial (1933), de Patrícia Galvão (Pagu), descrevia a luta dos operários divididos entre não-militantes e politizados; além dos romances de Jorge Amado que descreviam as populações pobres do campo e da cidade como Cacau (1933), Suor (1934), Jubiabá (1936) e Capitães da areia (1937). 
fala àqueles que não preenchem determinados requisitos sociais: uma censura social velada, que silencia os grupos dominados" (2012, p. 19).

Quando ingressa na faculdade de jornalismo em Juiz de Fora, em 1979, Ruffato vai então publicar por uma pequena editora local, Roseta Publicações, o seu primeiro livro, O homem que tece. A falta de perspectiva do operário das tecelagens, o trabalho como sinônimo de morte em vida, a falta de dinheiro, os desabafos no botequim, a violência doméstica e a ideia de São Paulo como terra prometida, já aparecem como tema central deste poema dedicado aos operários de Cataguases. Nota-se, no entanto, uma certa timidez na experimentação da linguagem que ainda aparece de forma direta, indignada e com um engajamento mais explícito.

sempre o barulho das engrenagens

Misturando ao ronco do estômago mal nutrido

A revolta que alimenta é grande

E esfomeada

A vontade de ser mais que um apagado peão $(1979$, p.11)

Ou mais adiante:

até quando?

Até quando vou ser uma voz apagada

Até quando vai durar a minha submissão

Quando meu deus

A nossa voz se somará

E será um grito uníssono? (Idem, p. 15)

Achado o tema de sua predileção, faltava ao autor, a forma adequada para expressar as suas ideias. Com a poesia clássica não alcançou a potência dramática a que queria chegar. O romance tradicional, oriundo do século XVIII, lhe parecia 
um "instrumento de descrição da realidade do ponto de vista de uma classe ascendente, a burguesia" (2008, p.321), ou seja, a ideologia do romance serviria à visão de mundo desta classe social. Além disso, a construção biográfica de personagens também não lhe agradava, uma vez que os seus personagens não têm biografia: "as enchentes levam os documentos, não sobra nada"11.

Diante deste impasse, passa a buscar sistematicamente, através de leituras dos mais variados autores, que ele considera terem construído a tradição do antiromance - Sterne, Xavier de Maistre, Richardson, Dujardin, Machado de Assis, Joyce, Proust, Faulkner, Robbe-Grillet, Pávitch e ainda os contistas Tchekov, Pirandello e Virgínia Wolf, os poetas Mallarmé e a vanguarda do século XX. (2008, “Até aqui tudo bem”, p. 321) - uma dicção própria, de modo que o conteúdo de suas narrativas tivesse paralelos com a forma de narrar.

Quase vinte anos depois, ele vai publicar um novo livro, Histórias de remorsos e rancores, pela Boitempo Editorial, de São Paulo, em que vai abordar novamente o universo do proletariado, mas agora apostando numa escrita que não é a poesia, o conto e nem o romance. É uma linguagem híbrida, fragmentada e tão lacunar quanto à vida de suas personagens, cheias de ausências.

Com a boa recepção do livro, ele publica em 2000, também pela Boitempo, (Os sobreviventes), trazendo à tona novamente a miséria financeira e espiritual de personagens da provinciana Cataguases, através de seis histórias habilmente amarradas, porém novamente fora dos padrões legitimados. No ano seguinte, publica o livro que o projetará nacionalmente: Eles eram muitos cavalos (Boitempo), vencedor dos prêmios da Associação Paulista de Críticos de Arte e Machado de Assis, da Biblioteca Nacional.

O "romance-colagem", dividido em 69 fragmentos narra histórias que se passam num único dia na cidade de São Paulo, dia nove de maio de 2000. Como sugere o título retirado de um trecho do poema $O$ Romanceiro da Inconfidência, de Cecília Meirelles, o romance bota em cena personagens anônimas, tais quais os cavalos da inconfidência, de cujos nomes, origens e pelagens ninguém mais se

\footnotetext{
${ }^{11}$ http://www.bienalpernambuco.com/\%E2\%80\%9Cos-invisiveis-\%E2\%80\%93-a-literaturaproletaria-brasileira-palestra-de-luiz-ruffato-na-bienal/ acesso em 07/03/2012.
} 
lembra. Trata-se de uma reflexão sobre a experiência de solidão e abandono vividos na megalópole.

Em Até aqui tudo bem, o autor comenta que em Eles eram muitos cavalos publicado também na Itália, França e Portugal - a cidade de São Paulo funcionaria como síntese da sociedade brasileira e que seria uma "reflexão sobre o agora" (RUFFATO, 2008, p.322), ou seja sobre aquele final de século, numa São Paulo cosmopolita, urbanizada, repleta de migrantes, violenta, favelizada e desigual.

Em 2005, Ruffato vai dar início à publicação da saga Inferno provisório, pela editora Record, que contará com cinco volumes que trazem à tona a formação, ou melhor, a má-formação da sociedade brasileira a partir da década de 1950 até os dias atuais. Se Eles eram muitos cavalos pretendia ser uma reflexão sobre o agora, a saga Inferno provisório procura entender, segundo o próprio autor, como chegamos até aqui e onde estamos (Ibidem). Por isso, o livro sobre São Paulo, embora publicado anteriormente, funciona como uma espécie de desdobramento da coletânea, dando o testemunho do autor sobre os dias de hoje. 


\title{
3. Como chegamos até aqui
}

\author{
"Não há cidadania no Brasil. A classe \\ média não requer direitos, e sim \\ privilégios". \\ Milton Santos, no documentário \\ Encontro com Milton Santos, de Silvio \\ Tendler.
}

Em sintonia com o pensamento de Néstor García Canclini, a saga Inferno provisório sugere que a sociedade brasileira se organizou de modo a sermos consumidores do século XXI e cidadãos do século XVIII. Nos últimos 50 anos, experimentamos a entrada no mundo do progresso, ou seja, de acesso a benesses do consumo e a importação de estilos de vida norte-americanos, sem passar por uma modernização, um desenvolvimento social adequado.

Assim, a Cataguases que aparece em Inferno provisório pode ser lida como uma espécie de microcosmo nacional, uma vez que a realidade vivida pelos cataguenses tem paralelos com a história vivida por muitos brasileiros nos quatro cantos do país. Em ensaio sobre a coletânea, Marcos Vinícius Ferreira de Oliveira, professor do mestrado em Literatura Brasileira do Centro de Ensino Superior de Juiz de Fora / Puc-Minas, chama a atenção para esta analogia:

\begin{abstract}
A história de Cataguases se parece com a do restante do Brasil e, por isso, ao situar as suas narrativas na cidade, sua obra lê o país? Ou Cataguases é um universo muito diminuto para que olhemos para a sua obra como possuidora de interesses mais amplos? O possível leitor verá que optamos pelo primeiro caminho, apesar de reconhecermos os riscos que a escolha enseja" (OLIVEIRA, 2013, p. 14)
\end{abstract}

Degeneradas em sua origem, como sugere a epígrafe ${ }^{12}$ de Jorge de Lima, usada por Ruffato nos cinco volumes da saga, a nau-cidade ou nau-nação não chegaram e nem chegam a lugar algum, não por falta de quem as guie no mar, ou

\footnotetext{
${ }^{12}$ Também há naus que não chegam / Mesmo sem ter naufragado: / Não porque nunca tivessem / Quem as guiasse no mar / Ou não tivessem velame / Ou leme ou âncora ou vento / Ou porque se embebedassem / Ou rotas se despregassem, / Mas simplesmente porque / Já estavam podres no tronco / Da árvore de que as tiraram.
} 
por não terem velame ou leme, âncora ou vento, "mas simplesmente porque já estavam podres no tronco da árvore de que as tiraram", dizem os versos do poeta.

Como avançar tendo recebido de herança uma sociedade colonial, escravocrata, dominada pelo latifúndio, onde a educação e o conhecimento foram sempre cerceados? Como se sabe, escolas, publicação de livros e jornais e reuniões para se discutirem ideias eram proibidas até a chegada da Família Real, em 1808. Laurentino Gomes, no ensaio histórico 1822, lembra que ao retornar para Portugal, em 1821, D. João VI deixou para trás dois Brasis: um repleto de barões, condes, arquitetos, artistas, fábricas de pólvora e manufaturas e outro pobre, descalço e atrasado, bárbaro e analfabeto.

De um lado uma elite, preocupada em garantir seus privilégios, uma espécie de white blocks - como propõe o historiador e deputado federal Chico Alencar, em artigo publicado em $O$ Globo (26/12/2013) -, parasitando o Estado brasileiro desde os seus primórdios, tendo seus privilégios renovados ininterruptamente, de modo que "seus espaços no poder são mantidos como capitanias hereditárias".

Esta elite é representada em Inferno provisório pela família "dos Pratas", donos de fábricas, nomes de ruas, ocupantes de cargos públicos, e meios de comunicação que acabam mantendo a antiga confusão entre o público e o privado da administração pública. E na outra ponta, uma população continuamente desassistida "sem cobre para um chapéu domingueiro, o dízimo da igreja, uma bicicleta aro-26"(RUFFATO, 2005a, p. 37), forma a massa de trabalhadores formais (geralmente qualificados e ligados à indústria têxtil); informais (desqualificados que atuam como pipoqueiro, pajem, lavadeira, prostituta, vendedor); e por último, os párias, um amontoado de desocupados, com a barriga encostada no balcão do botequim, escorrendo pelos poros a pouca dignidade que lhes resta.

$\mathrm{Na}$ tentativa de entender como chegamos até o estágio em que estamos, Ruffato transpõe para a ficção a sua interpretação do país resgatando uma memória coletiva nacional. $\mathrm{O}$ autor vai dos anos 50 no interior de Minas, quando o nosso perfil socioeconômico ainda seguia um modelo agrário, patriarcal, conservador e semifeudal, - até o início do século XXI, em que vivemos uma urbanização, segundo o autor, "desenfreada, desarticuladora e pós-industrial" 
(RUFFATO, 2008, p. 322), numa tentativa de espelhar a atualidade de um estado de coisas denunciado ainda em 1936 por Sérgio Buarque de Holanda em Raízes do Brasil.

Em seu fundamental estudo, Sérgio Buarque aponta algumas características da nossa cultura que teriam origens seculares, e que ainda se mantinham vigorosas em 1936. A incapacidade de separarmos a vida pública da privada, a ausência de espírito democrático - uma vez que adotamos um modelo de democracia que não se encaixa na nossa realidade sócio-política -, o personalismo, o patriarcalismo, o homem cordial (isto é, regido pelo coração / vontade pessoal e não pela lei / interesse público), a repulsa ao trabalho, a obediência servil daqueles que não tem outra opção de sobrevivência e a dificuldade de implantarmos uma cultura moderna em que a elite abrisse mão dos seus privilégios, ou seja, as raízes do Brasil faziam com que nós brasileiros nos sentíssemos "desterrados em nossa terra". O que Ruffato propõe em Inferno provisório é que esse sentimento não mudou muito de lá pra cá.

Além do tronco podre - que remete a um passado colonial, escravocrata e de educação precária - a coletânea aponta para a falta de rumo da nau-nação, 'engessada' num caminho sem saída, metaforicamente representado pelo beco do Zé Pinto. Lá vive em condições sub-humanas um amontoado de lavadeiras, domésticas, analfabetos, alcoólatras, desempregados, costureiras e operárioszumbis das inúmeras indústrias têxteis instaladas em Cataguases.

A Cataguases de Inferno provisório não é a da relevância cultural disseminada pela Revista Verde ou pelos conjuntos arquitetônicos modernistas. Foge ainda da visão de paraíso tropical que o discurso oficial insiste em exaltar, para se aproximar de uma representação do inferno/título da obra. Não o inferno do catecismo, de "labaredas fustigando condenados, tridentes sujigando pecadores, gritos de tardios arrependimentos"; mas outro inferno "encenado em certa casa náufraga, oculta atrás do bambuzal” (RUFFATO, 2005a, p. 40), ou numa rotina de trabalho maçante e sem perspectivas, ou na busca de um centro urbano maior, 'baú de promessas' nunca encontrado.

"Morte, migração e rompimento dos laços são uma constante" nos cinco volumes da obra, escreve Marcia Cerrano Castro, na tese a Construção do 
literário na prosa narrativa de Luiz Ruffato (2010, p. 68). Daí sermos levados a crer que o inferno representado por Ruffato é provisório porque dura só o tempo de vida de cada personagem e não uma eternidade, daí a morte ser tratada insistentemente como uma solução "preferível" a continuar vivendo mal (RUFFATO, 2005, "Sulfato de morfina", p. 32).

\subsection{Mamma son tanto felicce ou os problemas de hoje e de} sempre

A escolha do título do primeiro volume, Mamma, son tanto Felice, surge como uma ironia, pois, inspirado num verso da canção popular Mamma, de Cesare Andrea Bixio e Bruno Cherubini (1941), o livro de Ruffato se opõe ao conteúdo da música italiana que narra a volta de um filho aos braços da mãe amada prometendo não deixá-la mais. "Mamãe, eu estou tão feliz, viver longe por que?" ou 'Mamãe, eu estou tão feliz por estar voltando para você’.

Este primeiro volume vai tratar de outra questão. A desunião das famílias que vivem juntas no interior de Minas, a dúvida entre ficar ou partir e o duplo exílio daqueles que migram: a cidade grande não os acolhe e ao mesmo tempo a volta à terra natal é sempre problemática, pois o exilado já não pertence mais a lugar nenhum. É o que propõe Edward Said em Reflexões sobre o exílio: a migração representa uma "fratura incurável" entre o ser humano e a sua terra natal.

Embora a literatura e a história se esforcem por narrar episódios heroicos e românticos acerca do tema, tais relatos não passam de "esforços para superar a dor mutiladora da separação. As realizações do exílio são permanentemente minadas pela perda de algo deixado para trás para sempre” (2003, p. 46), diz Said. O migrante carrega consigo, propõe Ruffato em ensaio sobre a sua obra, "a sensação do não-pertencimento", fazendo com que a sua história seja continuamente refundada. 
Partir não é só desprender-se de uma paisagem, de uma cultura. Partir é principalmente abandonar os ossos dos antepassados, imersos na solidão silenciosa dos cemitérios. E os ossos são aquilo que nos enraízam numa história comum, feita de dor e luta, de alegrias e memórias. Rompido esse lastro, perambulamos sem saber quem somos (2010, "Até aqui tudo bem", p. 324).

Mamma son tanto Felice (2005a) já toca nessa questão da dor do exílio ao narrar a vida de famílias simples de origem italiana e apresenta personagens que vivem nos arredores de Cataguases, Serra da Onça e Rodeiro, nos idos dos anos 50 e 60 e que compõem uma sociedade em agonia e em completo desamparo. Bem distante do que aparece nas páginas das revistas $O$ Cruzeiro e Manchete neste mesmo período com seus concursos de misses, o nascimento da Bossa Nova, a conquista do campeonato mundial de futebol, em 1958, a construção da sofisticada nova capital, Brasília, inaugurada a 21 de abril de 1960.

O Brasil narrado por Ruffato neste primeiro volume é povoado por Bícios, Michelletos, Finnetos e os Spinellis, descendentes fictícios dos primeiros imigrantes italianos que entre 1880 e 1930, acuados pelas transformações socioeconômicas em seu país, vieram para cá. Minas Geraes, cenário de Inferno Provisório, recebeu nas primeiras décadas do século XX grande contingente de trabalhadores estrangeiros que lá se instalaram na tentativa de fugir da fome e do desemprego. É a essas famílias, desembarcadas do navio Carlos R., em Santos, repleto de "pulgas, baratas, percevejos, ratos", proprietárias "do impossível retorno" (Mamma son tanto Felice, 2005, p. 40), que vão perdendo seus vínculos com a terra natal, que Ruffato dedica o primeiro volume de seu Inferno.

Em Uma fábula ${ }^{13}$ primeira história de Mamma son tanto felice, Ruffato não cai no lugar comum de narrar uma vida rural e bucólica, cuja farta natureza acolhe os imigrantes vindos de além-mar. O episódio chama a atenção para a presença de uma violência fundacional, um quadro familiar em que a dureza (material e espiritual) está arraigada, e que vem desde a origem mais remota. As personagens são como as naus de Jorge de Lima que aparecem como epígrafe dos cinco volumes. Não chegam a lugar nenhum porque estão podres desde quando ainda estavam fincadas na terra.

\footnotetext{
${ }^{13}$ Segundo o dicionário Houaiss fábula é uma curta narrativa, em prosa ou verso, com personagens animais que agem como seres humanos, e que ilustra um preceito moral.
} 
O protagonista Andrezim nasceu de parto difícil, em que quase morre a mãe, "Micheletta velha", "doente todo o ano, embarrigada, esvaindo a mocidade pelos baixios, vinte anos de gravidezes, um estupor, treze rebentos - oito mulheres" (RUFFATO, 2005a, p. 15). O papel aprisionador da mulher, criada para cuidar do "lar" e para parir filhos homens, que ajudem na roça, é sufocante. Micheletta acumula gravidezes sem fim e sobrevive "desamparada, minguando num quarto de portas e janelas trameladas por fora" até morrer aos "trinta e cinco anos, rija, enrolada numa toalha de mesa" (Idem, p. 21).

O pai, "Micheletto velho", é um homem chucro, como diz a gíria mineira para designar uma pessoa grosseira, desprovida de cultura, que tem mais afeição pela criação e pela lavoura do que pelos filhos: "aquelas dão trabalho, mas alegrias", os filhos, "decepções apenas" (Idem, p. 16). Trabalhador árduo, “presidiário de sua obsessão", labutava desde "antes do sol espantar a roncaria da madrugada até os dedos formigarem de sono" (Idem, p. 16-17).

Se fábula é uma narrativa curta, em que personagens animais agem como humanos, o episódio narrado por Ruffato inverte o estado das coisas. O paterfamílias, senhor inconteste, é que vai agir como bicho, só conseguindo impor o respeito através da violência. Seja no desprezo pela mulher a quem não dirigiu a palavra durante anos, "desdenhando-a até na missa de corpo-presente, por entende-la inapetente para gerar filhos-homens", seja através da misoginia que carregava: acreditava que toda mulher guardava na intimidade das roupas “desgraças vindouras” (Idem, p.19).

A filha mais velha, que se deixou seduzir por um caixeiro viajante de passagem pela região, o pai, a cavalo, arrastou pelos cabelos.

\footnotetext{
Enlaçou numa corda e saiu puxando, ele montado, ela, nem pio, a pé, olhos recurvos, até que na encruzilhada da cidade alcançou-o o delegado, dois soldados. O Pai, tirando o chapéu, Se mete não, seu doutor, é distúrbio meu, vale a pena não, e o homem, atemorizado, dirigindo-se à moça questionou, você é filha dele?, e ela, casmurra, balançou a cabeça positivamente (Idem, p. 20)
}

O episódio escancara uma sociedade na qual a norma pessoal ou a vontade arbitrária de um indivíduo se faz mais respeitável do que a Lei, cujos 
representantes seriam o delegado e os soldados. O personalismo e patriarcalismo de que fala Sérgio Buarque de Holanda, em Raízes do Brasil, tradições de origem seculares em nossa cultura, se mantêm vivos nas histórias narradas por Ruffato.

Assim, Micheletto leva a "Madalena" para a subida da Serra da Onça para, na ignorância ao Estado, fazer, como diz o ditado, "justiça pelas próprias mãos"

Vai desgraçada, vai embora, vai pra bem longe, anda!, berrou, empurrando-a por entre touceiras de capim-gordura, ela, chorando, Pai, ele, apontando a espingarda, Vai, desgraçada, estou mandando, ela, Pai, e pôs-se a correr, desesperada, quando então a explosão de um tiro suspendeu os barulhos da tarde (Idem, p. 20).

O que se vê é a manutenção da velha ordem colonial e patriarcal, onde o talante do "homem cordial" a tudo prevalece, com todas as consequências morais, sociais e políticas que a ausência do Estado e da Lei acarretam e continuam a acarretar. Morta a filha, o pai, revestido de uma falsa piedade cristã, pede cinicamente aos seus criados que lhe cavem uma cova bem funda para enterrá-la: "pros bichos não comerem, é carne minha, e botem uma cruzinha em cima, é carne minha" (Idem, p.20), mandava.

O caixeiro viajante, em Mamma, son tanto Felice, representa - como bem destaca Rodrigo da Silva Cerqueira, doutorando da Universidade Federal de Juiz de Fora, no ensaio Ordem e Dominação - o progresso chegando ao campo, ou seja, uma nova configuração social invadindo o lar patriarcal. A morte, neste caso, "antes de crime, é contenção à possibilidade de ruptura de uma base que, mesmo gasta, quer-se plena" ${ }^{" 14}$. A chegada do caixeiro simboliza o primeiro passo da transição entre o campo e a cidade, mas uma transição que carrega continuidade, como uma espécie de "renovação conservadora", na qual em momentos de ruptura, a ideologia do período anterior permanece presente, como salienta Karl Marx, no 18 brumário de Luís Bonaparte ${ }^{15}$.

Com o "pé direito na igreja e com o esquerdo no botequim" (Idem, p. 24), de dia esculachado e à noite outro, Andrezim, filho dos Michelletos de "Uma

${ }^{14}$ In: http://www.ufjf.br/darandina/files/2010/01/Rodrigo-da-Silva-Cerqueira.pdf. Acesso em 18/12/2013.

${ }^{15}$ Idem 
fábula", vivia "iludido em cima de sua Göricke, espelhos retrovisores e campainha trim-trim no guidão, punhos com franjas multicoloridas, limpa-raios nas rodas, para-lamas e capa de selim com escudos do Botafogo, farol de dínamo" (RUFFATO, 2005, Mamma son tanto Felice, p. 23).

A bicicleta Göricke, marca alemã que passou a ser produzida em São Paulo a partir de 1955, é outro símbolo da chegada do progresso ao campo. A ilusão do menino revela, no entanto, que, como muitos que vivem na periferia do capitalismo, a sua inserção no mundo em vias de globalização só se dá através do consumo e não através da conquista de direitos básicos de cidadania. Ruffato sabe, está em "Até aqui tudo bem", que as barreiras caem para as mercadorias e não para as pessoas, "basta ver o retorno, com força da xenofobia, não só na Europa e Estados Unidos, mas mesmo aqui no Brasil” (2008, p. 322).

Na época globalizada, o exercício da cidadania é para Néstor García Canclini o sentimento de que pertencemos e de que fazemos parte de redes sociais a partir do consumo (1997, p. 20). O consumo de novos itens de conforto, no século XXI, representado por celulares e tablets "último modelo", cuja obsolescência, porém, é cada vez mais acelerada, faz com que o povo se sinta ilusoriamente participante privilegiado da pós-modernidade, ainda que faltem escolas, hospitais, moradia própria.

Fora a ilusão proporcionada pela bicicleta superequipada, resta a André o trabalho exaustivo e, nas horas vagas, se infiltrar numa rodinha de "conversa fiada, outra de truco apostado, outra de maledicência, outra de bobageira" (Idem, p. 23-24). O que vemos é que, com o avançar dos anos e o desenrolar dos capítulos e volumes da saga, a evolução social, representada pelas prerrogativas básicas da cidadania, não acompanha em nenhuma hipótese a chegada do progresso material sob a forma de bens de consumo. Assim, a corrosão social e o desejo de consumir se alternam nos episódios da pentalogia.

"Aquário", o terceiro episódio do primeiro volume, publicado anteriormente em (os sobreviventes) (Boitempo Editorial, 2000), aqui com pequenas alterações, encena o desgaste social que corre paralelamente ao crescimento da cidade e a expansão das oportunidades de trabalho, no seio de uma típica família ruffatiana, drama este que irá se repetir em muitas histórias de Inferno provisório. 
A mãe, D. Nica, dedica a vida à criação dos filhos - Fernando (ajustador mecânico formado pelo Senai, trabalhava na Saco-Têxtil), Carlos (que seguia os passos de Fernando), Norma (tecelã na Manufatora) e Nelson (vivia de bico peão, porteiro, caseiro, empacotador, frentista). É mais uma mulher que se transforma numa ruína em vida. "Minha mãe virou isso, um caco". A velhice vai minando os seus cabelos, "no rosto, os destroços. A dentadura dança saliente na superfície das gengivas. A pele vincada, os olhos resignados..." (RUFFATO, 2005a, p. 45).

O destino de Nica, assim como o de Chiara (a "Micheletta velha", de "Uma fábula"), D. Paula (a lavadeira com câncer, de "Sulfato de Morfina"), Bibica (a ex-prostituta, de “A mancha”), D. Fátima (a costureira de "A homenagem”), entre outras mães da saga, é dramático, carregado de "uma insidiante epiderme de mofo", "esporos furtivamente carcomendo qualquer esperança...assim nos primórdios...assim sempre...uma praga, uma maldição desembarcada do navio Carlos R., em Santos” (Idem, p. 40). Só lhes resta perder os filhos para o mundo. Seja na morte pré-matura, seja nas inúmeras migrações que se sucedem do primeiro ao último volume.

O pater familias, Adalberto, é, como Zé Bundinha (“A homenagem” e "Estação das águas”) e Orlando Spinelli (“A expiação"), alcóolatra, machista e violento, porém, dono de um moralismo amorfo e interiorano. Ao mesmo tempo em que dizia que botequim "não é lugar para gente honesta!", mas "lugar para puta e vagabundo!", frequentava as mulheres-damas da Ilha. E carteava a valer. E se emborrachava todos os sábados, domingos e feriados. Entretanto, "distribuía sacolinhas de balas e doces para as crianças" no dia de São Cosme e Damião, "arrecadava presentes para o Natal dos pobres" e "organizava peladas para a molecada do bairro" (Idem, p. 61).

Num ambiente de puritanismo e cafajestagem, os filhos de Nica crescem vendo e ouvindo o pai bater na mãe. De manhã, sem jeito, disfarçava o braço roxo, o olho roxo, a perna roxa. “'Bati na porta'. 'Bati na quina da mesa'. 'É essa lavação de roupa...Essa friagem que me deixa assim”,, disfarçava (Idem, p. 50). Certa noite em que o pai batia na mãe, Carlos decide: “"Pra mim chega!' Abri a porta do cômodo deles, arranquei meu pai de cima da minha mãe, encarei seus 
olhos esbugalhados e disse: 'Bate em mim seu filho da puta!'”(Idem, p. 51). Estavam rompidos os laços com a família - "eis tudo o que não fomos" (Idem, p. 62) - e deixa Cataguases para trabalhar numa firma de autopeças no ABC paulista. A violência contra D. Nica é também narrada de outro ângulo no episódio "Aquele natal inesquecível”, história que está no terceiro volume da série, Vista parcial da noite, e cujo protagonista é Fernando, o outro filho do casal. Depois de um exaustivo dia de trabalho no armarinho do Boi, às vésperas do Natal, Fernando encontra Nica em casa. "Uai, mãe, cadê o Lilinho?, o Nélson? No quarto comigo...e a posta roxa-rósea, do rosto deformado da mulher, De novo mãe? Num pulo ergueu-se, precocemente irritado". Encabulada, Nica tenta, em vão, amenizar a violência do marido. "Fica com raiva não, meu filho...nervosismo do seu pai...Ralhou com a Norma, comigo...deve ter bebido um pouquinho" (2006, p. 76).

Andrezim, o protagonista de "Uma fábula", é também vítima da violência doméstica que impregna estas narrativas de um Brasil socialmente parado no tempo:

e quantos roxos no corpo de André ainda desenhariam aquelas mãos? Uma birra, uma cisma, um desgoverno....uma desinteligência, tudo dava nos nervos do Micheletto velho, que, cego, usava o que estivesse à frente, acha, porrete, corrião, vara de marmelo, bambu, relho, chicote, cacumbu, até quando?, revoltava-se, até quando? (RUFFATO, 2005a, 22).

"Bobageira estudo", filosofava um dos filhos de D. Paula, a lavadeira protagonista de "Sulfato de morfina". A forma mais recorrente de manter a velha ordem patriarcal é a surra, como pensava Virgílio, seu outro filho. Para ele, era "tão natural bater nos seus quanto comer, beber, cagar, espancando-os com mãos próprias ou fosse o que fosse, acha, chicote, bambu, corrião, tala, cabo de vassoura, marmelo, galho, qualquer salmoura cura" (2005a, p. 38).

"A expiação", publicado anteriormente em (os sobreviventes) também pode ser considerado um episódio modelar, no sentido de que apresenta os elementos centrais que compõem o universo do lúmpem ruffatiano: alcoolismo, violência doméstica, precariedade material e espiritual, racismo, morte, migração e violência urbana. Dividido em três subcapítulos - "Ritual", "Fim" e "Tocaia" - os 
episódios relatam, fora da ordem cronológica, um mesmo acontecimento, sob diferentes pontos de vista e temporalidades, e conjugam temas recorrentes nas histórias.

"Ritual", que vem a ser cronologicamente o "meio" da história, conta o drama do menino Zé, de 13 anos, filho de Orlando Spinelli e D. Assunta, que vivia com os pais e irmãos numa casa simples em Rodeiro, zona rural próxima a Cataguases. Se a princípio as imagens das galinhas ciscando o chão despreocupadas, o cachorro espreguiçando-se à sombra das bananeiras e uma dupla caipira se esgoelando no rádio vizinho (2005a, p. 75) são reconfortantes, a vida do menino não é tão alentadora assim. Ao longo da narrativa ele se culpa por não conseguir sofrer diante da notícia da morte do pai, despencado de uma ribanceira numa de suas "carraspanas dominicais". Ao invés de tristeza, alívio: "sentiu uma apreensão esquisita, uma sensação ruim, um desejo de que...seu pai...não, não podia pensar isso...acabar com aquele sofrimento...a mãe..." (Idem, p.76). Sua única preocupação era o paradeiro de Badeco, seu irmão de criação, acusado pelo acidente com Orlando e desaparecido desde então.

Zé desejava lembrar-se das coisas boas que Orlando fazia, mas, na verdade eram "os safanões que tomava quando o pai estava alto que se sobrepunham, os cascudos, os tapas na bunda, os beliscões doloridos, com ou sem motivo" (Idem, p. 83), daí o alívio com a sua morte: "agora não haveria mais brigas, ninguém mais apanharia só porque o pai estava bebido, e eles poderiam viver felizes" (Idem, p. 84).

Conhecido por ser um "sujeito pacato e justo", "respeitador da mulher alheia" Orlando "selvajava-se com um tico de álcool na boca". Tornava-se agressivo, batia na mulher e nos filhos, mexia com moças e senhoras, batia boca com os vizinhos, judiava dos bichos de criação e do próprio afilhado, o menino Badeco, ridicularizando-o em público. Depois de uma semana "cabisbaixo, envergonhado" (2005a, p. 82), ressurgia "endemoniado", "valentão", "rancatoco", "o-que-nada-teme" (Idem, p. 83). Como todos os domingos, Orlando saíra acompanhado de Badeco dizendo ir à missa, embora todos soubessem que estava a caminho do bar. A diferença é que no fim da tarde voltava capengando 
amparado pelo afilhado, e no seu último domingo "não havia retornado, nem sóbrio, nem bêbado" (Idem, p. 82).

O mito da democracia racial disseminado por Gilberto Freyre em Casa Grande \& senzala não serve na racista e puritana Cataguases de Inferno provisório. Badeco passa de pretinho esperto e danado a "preto ranhoso" ou "o capeta" (Idem, p. 80), após o acidente com Orlando. "Não se pode fiar em gentese-cor" (Idem, p. 77), diziam uns. Orlando dava "muita asa para esse negro" (Idem, p. 79), diziam outros. E ainda de Remundo, ele mesmo negro: “Tem preto que não conhece o seu lugar" (Idem, p. 87), repreende.

O velório de Orlando Spinelli é cortejado por membros da congregação do Coração de Jesus, o comércio cerrou as portas, todos a postos para homenagear o "santo homem" que batia na família e insultava os conhecidos, como tantas figuras masculinas que habitam as páginas de Inferno provisório.

No subcapítulo "Fim" - a segunda parte da história dividida em três capítulos - o narrador dá um salto no tempo e no espaço para contar em zig-zag as memórias senis de Seu Jair, o idoso protagonista do conto que agoniza num leito de hospital clamando por forças divinas - "Que provação, Senhor!” (2005a, p. 92) -, e sua difícil trajetória de homem pobre, negro e migrante. O cenário agora é São Paulo dos anos 1970/80, da escalada da violência, da proliferação dos cultos evangélicos, da favelização, dos grandes magazines.

A perda dos filhos, Caveira e Jacaré - apelidos de Jairzinho e Orlando -, metidos com drogas, a tentativa de tirá-los do erro com suas orações e vigílias e até mesmo com o seu exemplo "de homem trabalhador, honesto, correto, bom pagador" (Idem, p. 92), são algumas das preocupações de Seu Jair. O primeiro flerte com Rosa, a esposa, colega de culto da Igreja Deus é Amor também é rememorado. Um dia, na Praça da Sé, o sucinto e afetuoso diálogo cria uma atmosfera que resume a simplicidade das personagens-migrantes que para ali escorrem dos quatro cantos do país em busca de melhores condições de vida: "A irmã aceita um picolé? A irmã aceitou, dentro dele balões-de-são-joão. Na casa de uma Senhora na Mooca. Num quartinho de fundos, alugado, em Santana. Da Bahia. Sou mineiro. Balconista das Lojas Brasileiras. Motorista de ônibus" (RUFFATO, 2005, p. 94). Daí em diante, a união do casal. 
Moradores de Jardim Peri ${ }^{16}$, zona periférica de São Paulo, constroem com a ajuda dos irmãos da igreja, uma pequena casinha: "assentaram o vaso sanitário; degrau por degrau, vinte e cinco no todo, desceram a escada até a rua; levantaram o muro, bateram a laje; rebocaram e caiaram as paredes. E Deus abençoou o casamento. Sem luz, sem esgoto, sem água” (Idem, p. 94-95).

Com os filhos, aquilo que se chama de 'progresso' foi chegando: “Josué, luz elétrica, rede de esgoto e água; Jairzinho, asfalto e um puxado com mais dois quartos; Orlando, supermercados e lojas e mais um andar com banheiro; Rute, posto médico e um quarto só para ela" (2005a, p. 94-95). Mas também, com a chegada desta infraestrutura mínima, a violência e a desagregação familiar se impõem, mostrando que a modernização material não veio acompanhada de dignidade e perspectivas de vida para a população.

Ao perder dois filhos e depois a esposa, Seu Jair, consternado no leito de hospital, diz ao pastor que o visitava: “essa dor são os mortos...meus mortos...apodrecendo dentro de mim [...] Deus não é amor...É vingança....é punição..." (2005a, p. 98), desespera-se. E ele a tudo aguentando, "porque era homem, e um homem a tudo tem que aguentar". "Preferível a morte, preferível a morte" (Idem, p. 99), lamuriava-se, tal qual D. Paula, a lavadeira com câncer, de "Sulfato de Morfina" (RUFFATO, 2005a). Sem grande espalhafato, o narrador sugere que Seu Jair vem a ser Badeco, o menino responsabilizado pela morte do padrinho Orlando, na história anterior e que foragido, viera parar em São Paulo. Neste caso, vale mais uma vez a metáfora da nau podre, ou ainda, do ditado "pau que nasce torto, nunca se endireita" e suas variações: "pau que nasce torto, até a cinza é torta" ou "pau que nasce torto vira lenha". Os passageiros dessa embarcação também não chegam a lugar algum.

Já em "Tocaia" - terceiro e último subcapítulo da história - acompanhamos do ponto de vista de Badeco a causa mortis de Orlando, reforçando a recusa do autor à ordem e ao progresso, prerrogativas da narrativa linear. Neste episódio, o narrador propõe a origem do desentendimento entre padrasto e afilhado: Badeco teria rido de Orlando por ele ter errado a bola de sinuca. "Tá rindo de quê?, negro

\footnotetext{
${ }^{16}$ Bairro carente da zona norte de São Paulo pouco urbanizado, que, segundo informações da Wikipédia, ainda hoje tem problemas de asfalto, canalização de esgoto e fiscalização de trânsito. Fica a 40 minutos do metrô e a 50 minutos do trem.
} 
safado!" (2005a, p. 103), pergunta invocado e partindo para cima do rapaz. "Agora, macaco de uma figa, você vai dar uma volta no jardim, bem bonitinho, igual a um tiziu! Badeco resistiu, mas Orlando pegou o relho e deu-lhe duas chibatadas nas costas. Ai, padrim!, Ai, padrim!" (2005a, p. 104), de modo que o autor refaz com requintes de crueldade a cena em que Brás Cubas, ainda menino cavalga às costas de Prudêncio, o escravo que lhe serviria a vida toda.

Os arruaceiros da cidade divertem-se com o episódio, mas a cena de violência é logo abortada por um policial negro. "Ué, um macaco veio salvar o outro?", debocha Orlando (Idem, 104). Humilhado, Badeco deixa a cena rumo de casa e, alcançado pelo padrinho na estrada, com a ideia de assustá-lo levantando um porrete no ar, acaba assustando o cavalo que desaba barranco abaixo com charrete e passageiro junto, matando este último. A morte desencadeia a fuga do menino, a migração forçada e a perda de laços e vínculos com o passado.

Encerram o romance os episódios "O alemão e a puria" e "O segredo" que será comentado mais adiante. Aquele narra a história de Dusanjos, lavadeira jovem que, ainda com filho pequeno, é abandonada pelo marido, o abobalhado Donato. Desolada, catatônica, desejando morrer, acaba recorrendo às mais variadas religiões aqui representadas como engodo. Primeiro procura o espiritismo, sendo conduzida ao Centro Espírita Bezerra de Menezes, onde escuta a conformista mensagem de que "todos os nossos percalços são degraus a serem vencidos em nossa caminhada rumo à perfeição" (2005a, p.118). Sem repostas convincentes em relação ao sumiço do marido, desiste da doutrina kardecista e busca ajuda na umbanda encontrando a "bruxa" Sá-Ana, pronta para "benzer um mau-olhado, uma espinhela caída, um pé destroncado, um pulso-aberto" (Idem, p.119).

Em sua casa, ícone do sincretismo religioso, a velha vive cercada por ervas daninhas, cachaça, jurubeba, cana de macaco, um preto velho pitando um cachimbo, além de dois quadros, o Sagrado Coração de Jesus, representando a igreja católica e outro de Iemanjá, representando a orixá de matriz africana. Aumentando o ritmo das palmas, Sá Ana começa a cantar mais alto, e a girar, girar, girar, até que, de repente exausta, bebe aguardente, e, transtornada, senta-se num tamborete. Já não era mais Sá-Ana. A bruxa incorpora o espirito de Tia Joana 
e diz: "Quando você nem lembrar mais disso, as coisas mudam...Ele volta, Tia Joana?, quer dizer que ele está vivo? Minha filha, o que a gente quer é o que acontece" (2005, p. 120-121).

Um ano depois, Dusanjos aceita o convite de Marlindo para participar de um culto da Cruzada Evangélica. No púlpito, com o microfone na mão, torna-se exemplo. "Eu estava cega e surda, mas Cristo-Jesus me iluminou (Aleluia, irmãos!)", brada. O pastor Namir, líder do culto, banca o adivinho: explica que Donato cometera "o maior dos pecados, Tirou a própria vida!" (2005a, p. 122). Contrariando a sentença do pastor, dois anos depois, Donato reaparece causado alvoroço no beco do Zé Pinto.

O recurso ao sagrado funciona como forma de preencher o vazio deixado, neste caso, pelo sumiço de Donato. A representação do religioso, contudo, é retomada em diversas passagens de Inferno provisório como subterfúgio para aplacar a dor provocada pelo esgarçamento dos laços familiares e comunitários desencadeados pela migração em massa. De uma maneira abrangente, o romance traz à tona um tema caro à interpretação da cultura nacional: a religiosidade do brasileiro. Diz Carmen Cinira Macedo, em Imagem do eterno: religiões do Brasil, que aqui, "mesmo as pessoas que não se preocupam muito com a prática religiosa, acabam se interessando por casar na igreja e batizar os filhos. Afinal, casamento sem noiva e crianças sem padrinhos são quase inconcebíveis no cenário cultural brasileiro" (1989, p.6). Ou ainda a existência de despachos, dias santos, festas religiosas não passam desapercebidos.

O tema é apresentado em Inferno provisório dos mais variados ângulos: seja numa conversa: "Meu Deus, é um provação?” (Idem, p. 159); numa saudação: "Aleluia, irmãos" (Idem, p. 119); na presença recorrente de igrejas nos cenários descritos; no ir e vir de personagens aos cultos; na celebração de datas como o Natal e o dia de Cosme e Damião; no título do quinto volume da saga Domingos sem Deus (2011) ou ainda na epígrafe que aparece também nos cinco volumes: "E Daniel disse: Tu te lembraste de mim, ó Deus, e não abandonaste os que te amam" (Daniel 14:38). 


\subsection{0 mundo inimigo regido pelo consumo}

Ernest Renan escreve em seu seminal ensaio “O que é uma nação?” (1882) que a essência das comunidades nacionais corresponde a um princípio espiritual, que consiste num rico legado de lembranças e esquecimentos e num desejo de viver juntos. "A nação, como o indivíduo, é resultado de um longo passado de esforços, de sacrifícios e de devoções". O capital social de uma nação estaria assentado num "passado heroico, grandes homens e glória" (1997, p. 39), ainda que carregados de fantasia e imaginação.

Em Inferno provisório, no entanto, a ideia de pertencer a uma coletividade, ou seja, de ter um passado comum e identificado e de se esforçar para zelar pela memória da cidade e pela origem coletiva dos habitantes que nela vivem é suplantada pelo desejo individual das personagens de consumir bens concretos e simbólicos, geralmente encontrados na metrópole.

$O$ mundo inimigo traz uma Cataguases mais urbanizada, com fábricas, televisão, rádio, cinema, além de veículos automotores, como fusca e cataníquel, em contraste com as bicicletas e charretes predominantes na vida rural de Mamma son tanto Felice. Os problemas de alcoolismo, machismo, violência doméstica, no entanto, se mantêm, e outros surgem, como a contravenção (jogo do bicho, prostituição, agiotagem), roubos, violência policial e injustiça social, agravando ainda mais o sentimento de não pertencimento dos protagonistas.

O episódio "Amigos” problematiza mais uma vez a não coincidência entre o progresso (material e tecnológico) e uma modernização dos costumes e direitos. O romance traz à tona os efeitos negativos desta modernização desigual que deixa intactas as bases arcaicas da sociedade e acaba por criar novas contradições. Passados 10 anos, o reencontro dos amigos de infância Luzimar e Gildo, numa tarde de Natal, nas redondezas do Beco do Zé Pinto é o gancho para botar em cena a violência que acompanha a chegada do progresso.

Luzimar, que ficou em Cataguases, é operário da Manufatora e representa a estagnação. Pobre, anda de bicicleta e com as mãos sujas de graxa. Gildo, que partiu para São Paulo, representa a prosperidade. Enriquecido, veste bermuda 
jeans, camiseta de propaganda e é proprietário de um fusca 1300, além de ter presenteado a mãe com uma TV nova “último modelo, uma nota!” (2005b, p. 19).

O primeiro é inocente e resignado, enquanto o que partiu, ousado e agressivo. Se a princípio os dois conversam amigavelmente sobre histórias da infância, - a escalação do time de futebol, as tardes de gibi, o trabalho e o paradeiro dos amigos do grupo, conforme vão bebendo cerveja, Gildo vai se tornando mais e mais violento. O seu status, ter "se dado bem", exerce sobre Luzimar um poder gravitacional, uma vez que ele não consegue ir-se embora.

Gildo foi para São Paulo, cidade "boa para ganhar dinheiro", arrumou emprego, ganha bem: "comprei até carro, você viu?, um fusquinha verde aí fora, mando dinheiro para a mãe...” (2005b, p. 21), mas não esconde o rancor de ter precisado partir: "Essa cidade é uma bosta, não tem nada", “- cidade de merda! Povinho escroto" (Idem, p.21), esbraveja.

Acuado, Luzimar tenta despedir-se algumas vezes, mas de certa forma, sente-se preso ao espetáculo encenado pelo amigo "próspero". A preocupação de Luzimar é outra, mais comezinha: levar uma lembrança de Natal para Soninha, sua esposa, "tenho de arrumar dinheiro", especulava pedir emprestado ao agiota do bairro, "seu Zé Pinto, quem sabe o décimo terceiro ela merece" (2005b, p. 15). Ao que Gildo propõe, “depois te levo pra casa [...] já pensou?, você chegando lá de fusquinha?, heim? Vai fazer a maior figura não é não?” (Idem, p. 22). Sem jeito, tenta escapar, com o argumento da noite de Natal que se aproxima, o presente que ainda não conseguiu comprar, mas Gildo insiste na tentativa de prendê-lo para que assista ao espetáculo da sua ostentação e agressividade.

- Que isso cara! A gente vai lá (na Rua do Comércio) e você compra um presente bem bacana...Um...uma...uma gargantilha, por exemplo, heim?

- E eu lá tenho dinheiro para isso?

- Uai então eu pago! Está acertado! É isso! Resolvido! Daqui a pouco a gente vai lá na rua do comércio e compra uma gargantilha pra ela, certo? Então vamos beber mais uma cerveja... (RUFFATO, 2005b, p. 23) 
Gildo prossegue no seu discurso de que Cataguases é uma cidade sem horizontes e sem perspectiva, que “o mundo está é lá atrás. O mundo, cara! Essa cidade é uma merda!” (Idem, p. 24), revolta-se. Mas, ao perceber que Luzimar não compartilha o horror que Gildo sente pela cidade, sua agressividade volta-se para o amigo. Assustado, Luzimar "panha a bicicleta e sai pedalando rapidamente". Os insultos de Gildo ecoam no ar: "Vai, panaca, vai cuidar da mulherzinha! Vai, bundão! Trouxa! Panaca! Vai!", grita, acendendo um "rastilho de lâmpadas nas casas vizinhas" (Idem, p. 25).

Os que ficam na cidade são representados como "panacas", interioranos, kitsches, resignados e doentes, e os que partem são imaginados como heróis, corajosos, os que "se deram bem" e, embora agressivos, são responsáveis por trazer para a cidade o que há de mais moderno nos grandes centros.

Assim, capítulo a capítulo, ônibus descem ligeiro a Rio-Bahia rumo ao Rio de Janeiro e São Paulo apinhados de gente em busca de oportunidade de emprego nas grandes cidades. A substituição das importações e o estabelecimento da indústria de base, que marcaram a era Vargas e a euforia desenvolvimentista dos anos JK, somadas ao 'milagre econômico' dos anos de ditadura, recrutam trabalhadores de diversas partes do país. "Não voltam nunca mais, nunca mais" (RUFFATO, 2005a, p. 49). Escapolem da falta de perspectivas da vida interiorana deixando para trás a família e a terra natal, entendidas como fardos.

O desprezo pela terra natal é comum, por exemplo, a Gilmar e Gesualdo, respectivamente irmão e tio de Gildo, que aparecem no episódio seguinte, "A demolição" (O mundo inimigo, 2005). Embora já estabelecido na cidade grande, Gesualdo tinha ojeriza a Cataguases, chegando a esbravejar: "Bosta de lugar!, dizia, escarrando no cimento da calçada, Nada aqui vai para frente!”, cuspia azedo, enquanto se esquivava dos conterrâneos em São Paulo para não lembrar hora alguma de sua origem (2005b, p. 30). Com a morte de Marciano, seu irmão, Gesualdo vê-se na obrigação de visitar os sobrinhos e tirá-los da vida de "mágoas e desesperança" que assolava a pequena cidade mineira.

Gilmar é levado pelo tio a tentar a vida como jogador de futebol em São Paulo. "Marta, o menino permanecer aqui é desperdício", diz à cunhada. "Já imaginou?, vai que ele engrena, acaba na seleção, enche o bucho de dinheiro, fica 
famoso, heim?" (Idem, p. 30). Gilmar acreditava que sua vida ia começar a andar logo que sumissem "na curva da estrada as luzes dos postes da Vila Minalda, que boiavam nas águas mansas do Rio Pomba, última imagem de Cataguases" (Idem, p. 31). "Estamos cruzando o inferno, Gesualdo brincou [...] Estamos cruzando o inferno, Gilmar repetia, baixinho, Cataguases ficou para trás, Nunca mais, jurou, Nunca mais" (Ibidem).

A matriarca da família, D. Marta, costureira reumática que vê a família se dispersar rumo a São Paulo e Muriaé, passados 45 anos, decide vender a casa da família para ir viver com as irmãs em Santo Antônio de Pádua. Sabia ser impossível cultivar o desejo de "ter um dia, mesmo após a morte, a família toda reunida no túmulo em que jaziam o marido, Marciano, e a Lia" (2005b, p. 29) filha que o tifo levou ainda menina. "Não aguentava mais a canga da solidão, os filhos distantes" (Idem, p. 33).

Em meio às discussões acerca da divisão do dinheiro da venda da casa Gilmar maquinava realizar o sonho das filhas de visitar a Disney, e Gildo, "sempre bobo, sentimentalão", confessa que "ia sentir falta da casa" (2005b, p. 34) -, os irmãos são surpreendidos com a notícia de que a nova dona iria botá-la abaixo.

- Sabe o que a Dona Eucy vai fazer com a casa?

- Hum?

- Vai derrubar...

- Derrubar?

- É, quando eu penso nisso dá até um...

- Derrubar, Gildo?

- É, pôr abaixo...Eu sinto até um...

- Gildo, você tem certeza?

- Estou falando, sô! Ela disse que vai demolir tudo, a nossa casa e a dela, e construir uma outra, maior, no lugar...Você sabe, o Lucas, aquele filho dela meio veado, que foi pros Estados Unidos..

- Demolir, Gildo? Não é possível!

- Caralho! Achei que você não estivesse nem aí... (2005b; p. 35). 
Mesmo tendo comprado um terreno no Cemitério das Colinas, em São Bernardo do Campo, para se assegurar de que não havia risco de voltar para Cataguases nem morto, Gilmar espanta-se com a notícia. $\mathrm{O}$ vazio se instala no lugar da origem familiar. Embora rejeitem a terra natal, cada um à sua maneira, a ideia da destruição da casa lhes causa horror, uma vez que o apagamento do passado se mostra definitivo. As lembranças da infância no quintal, feito "campo de futebol. Traves de chinelos e quinas, bolas pererecando por entre as pernas magoadas dos moleques" (2005b, p.36) e da mãe "vergada sobre a toalha de plástico verde que cobria o tampo da mesa da cozinha" (Idem, p. 36) catando feijão, ressurgem fantasmagóricas.

Passado familiar e passado nacional se entrelaçam na narrativa ajudando a compor uma imagem arruinada da nação. Se na esfera particular, vemos famílias se desestruturando por conta da violência e das inúmeras migrações ou uma casa demolida, que perdeu a serventia, na esfera pública, acompanhamos a manutenção de problemas histórico-sociais do país que ressurgem feito assombrações no âmbito das casas particulares.

Em "O Barco", por exemplo, terceiro capítulo do livro, o foco narrativo zigue-zagueia pelos contrastes entre uma abastada família da cidade e seu Marlindo, empregado da casa. O texto é rico em expressões asfixiantes, que denotam a mesmice, a pasmaceira e a esterilidade do ambiente. Seu Marlindo aparenta ser muito mais velho do que é, como tantas personagens que, por excesso de trabalho combinado à precariedade da saúde, envelhecem precocemente: "tinha quarenta e três anos - o povo daria bastante mais" (2005b, p. 43). Os resultados de ter comido "o pão que o diabo amassou" são "cabelos devastados", rosto escavado, covas enegrecidas (Ibidem). Depois de tentar a vida como faxineiro da Industrial e pipoqueiro, agora "sobrevivia" como pajem de Osvaldo, um rapaz abilolado da abastada família, sonhando para o filho Luzimar uma inserção no mundo do trabalho e do consumo:

um curso de torneiro mecânico no Senai. Ou de ajustador mesmo, já estava bom. Morando em São Paulo. Endinheirado. Sem precisar de passar necessidade. Dando de presente para a mãe uma geladeira. Ou uma enceradeira. Orgulho da família. Bem falado (2005b, p. 45). 
Ao mesmo tempo em que vai descrevendo os desejos e anseios da família de Marlindo - que "dera duro para engrenar como gente" (Ibidem), a narrativa vai também revelando a aspereza da história da Dona Geralda, a patroa, viúva de um respeitado médico da cidade, Romualdo, e que desprezava o empregado. Marlindo nunca pôs

sequer o bico da botina no assoalho da sala. Na cozinha entrara uma que outra vez, desabusado, para encher um copo d'água na talha ou para sujar o fundo de uma caneca de café da garrafa-térmica. A comida engolia na varanda, sentado nos degraus da escada que dava para o quintal, prato equilibrando na planta da mão, garfo virando a massa do arrozcom-feijão, angu-e-couve, uma isca-de-carne (RUFFATO, 2005b, p.56).

Além de Marlindo, Adelaide, agregada da casa, também é vítima dos resquícios escravocratas que assombram as relações de trabalho entre as famílias brasileiras mais abastadas e seus funcionários. Desde os 8 anos de idade, vivera na casa dos pais de Romualdo, onde de tudo fazia, do café da manhã à janta, costurava roupa e cuidava das crianças. "Todos os dias. Inclusive sábados, domingos e dias-santos-de-guarda" de modo que, como uma escrava, cresceu "sem tempo para entender o que estava acontecendo à sua volta" (Idem, p. 48). Morta a matriarca da família, Adelaide "pegou-se com trinta e tantos anos, sozinha, sem lar, sem dinheiro, sem família, sem nada”. Os herdeiros "agradeceram por tudo, deram-lhe uma correntinha de ouro, com uma medalhinha de Santa Rita de Cássia, como lembrança e paga, despediram-na” (Idem, p. 48).

A cena ilustra, para Marcus Vinícius Ferreira de Oliveira ${ }^{17}$, o flagrante contraste entre a ideologia liberal importada da Europa burguesa e ilustrada e a prática escravista brasileira que resultou no que Roberto Schwarz chamou de "ideias fora do lugar", em Ao vencedor às batatas (1988). O trecho reforça mais uma vez o continuísmo da velha ordem colonial e escravocrata numa realidade retrógrada que se quer moderna e civilizada. A era do automóvel e da televisão, mas também de regimes de trabalho análogos à escravidão, da exclusão social, do racismo, do clientelismo.

\footnotetext{
${ }^{17} 2013$, p. 169.
} 
Tais contrastes impossibilitam pensar o tempo nacional como "homogêneo e vazio", como propunha Benedict Anderson, um dos principais teóricos do nacionalismo, em Comunidades imaginadas. De acordo com o indiano Partha Charttejee, no ensaio La nación en tiempo heterogéneo (Madrid. Paidós, 2009), um marxista diria que o tempo homogêneo e vazio é o tempo do capitalismo e não contempla nenhuma resistência. Quando encontra um impedimento, interpreta-o como resíduo pré-capitalista ou pré-moderno. Tais resistências ao capitalismo, ou à modernidade são interpretadas como remanescentes de um passado superado e que, sem embargo, por algum motivo, persiste.

Coincidindo com as circunstâncias narradas por Ruffato, Chartejee acredita que nas sociedades periféricas, de passado colonial, a modernidade não se instala de maneira igualitária. Tais sociedades se constituíram de acordo com modelos baseados em conceitos universais, como cidadania, sociedade civil e democracia que não existiam previamente (2009, p. 10). Por isso, o tempo dessas nações periféricas é desigual, constituído das diferentes experiências de diferentes grupos sociais. O tempo real delas seria heterogêneo e desigualmente denso, convivendo democracia e nepotismo, liberalismo e escravidão, urbanização e favelização. Para o autor, a modernização vem acompanhada de contradições, ou seja, de resquícios de um tempo bárbaro (2009, p. 116).

Romualdo, falecido marido de D. Geralda, por exemplo, é protagonista de uma flagrante cena de clientelismo político em plena democracia. Médico e vereador, "Fiava-se no afamado entra-e-sai de gente em busca de uma consulta grátis, de uma remessa de tijolo, pedra ou areia, do pagamento de uma conta pendurada, de uma palavra amiga (2005b, p. 53). As eleições, Romualdo vencia uma após a outra, "ajeitadas pelas mãos dos Prata”, família de grandes posses e influência na cidade. Antes de entrar na seção para votar, "o eleitor soletrava o nome para o cabo-eleitoral conferir na lista dos empregadores das fábricas. Se as urnas parissem menos votos que os garantidos, ia a fieira inteira para o olho da rua. Sem dó, nem piedade" (v. 2, p. 55-56). O trecho revela arcaicas táticas de fraudes eleitorais agenciadas pelos "donos" da cidade.

O movimento pendular entre os corajosos que deixam Cataguases e os resignados que ficam na cidade se intensifica neste segundo romance. Zito Pereira 
é o protagonista de "A danação". Natural da Serra da Onça, onde ajudava o pai na roça decadente de milho e fumo, é mandado aos 10 anos para Cataguases para arranjar-se nos fundos de uma oficina mecânica. De lá, atira-se à vala comum, São Paulo. A personagem conhecida pela alcunha de "mineiro" afunda-se num universo de multidão e solidão tão comuns à cidade grande. Sua percepção da pauliceia desvairada é filtrada pelo saudosismo da terra natal. Onde há "pessoas zanzando esbaforidas" ele vê "casais de braços dados rodando a praça" (2005b, p. 136), onde há o "odor da fumaça dos ônibus e dos carros" ele sente o "cheiro de pipoca que inundava o centro da cidade [de Cataguases], sábado à noite" (Idem, p. 136).

A experiência na megalópole intensifica a ideia de não-pertencimento. "Mineiro. Nem nome tinha. Mineiro. Na firma em Diadema, na pensão do Ipiranga. E nem isso quando percorria, anônimo, a cidade" (Idem, p. 139) dos cartões postais: aeroporto de Congonhas, Ibirapuera, Praça da República, Rodoviária da Luz e os mais variados cinemas.

Decepcionado com o término do namoro com a cearense Gracinha, que por uma briga o agride, chamando-o "Urubu, pau-de-fumo, tiziu, bola-sete..." (2005b, p. 139), após 3 anos de São Paulo, sentindo-se um "mequetrefe" na cidade grande, saudoso da terra natal, resolve voltar. Um baiano, que trabalhava com ele, ainda falou,

Mineiro, eu estava bem aqui, comprei passagem pra serrinha, larguei tudo. Dei com os burros n'água. Tive que voltar com o rabo entre as pernas. O Brasil tem jeito não. Só aqui a gente veve decente, sabendo que pode contar com ordenado certo no fim do mês (Idem, p. 140).

Mesmo assim, Zito decide voltar e se casa com Hilda, com quem tem 5 filhos. Ao contrário de Gracinha, a dona de casa do interior era zelosa e dedicada às tarefas domésticas: "arroz cozido, o feijão com toicinho fumegando na panela, o angu esfriando o prato em cima da mesa” (Idem, p. 137). Mas Zito, em sua eterna condição de migrante não cria raízes, pensando ter sempre deixado para trás uma parte de si. "E se eu tivesse ficado lá em Serra da Onça?" Ou "E se eu 
não tivesse saído de São Paulo?” (Idem, p. 139), desespera-se por não se sentir em casa onde quer que esteja.

O episódio que segue, "A decisão" se ocupa de narrar a história de Vanim, mais um que decide tentar a vida fora de Cataguases. Por uns tempos, o protagonista conseguira se enquadrar na vida de homem casado e trabalhador, aposentou o violão "que dividia a parede da cama-de-casal com um crucifixo de madeira, presente da sogra, santa mulher" (2005b, p.148). Pouco depois

sentiu um troço esquisito, uma gastura. O tempo correndo desembestado, e ele ali, feito bobo, fazendo o que com a vida que Deus, em sua infinita bondade, lhe tinha dado? Burrode-carga, trabalharia até morrer, sabia, viriam filhos, aí, danou, acabaria como aquele sô-zé, que envelheceu e ninguém mais quer (Idem, p. 149).

Enfiou na cabeça que voltaria à cantoria, às serestas. "Não podia se dar ao luxo de morrer assim, hora para outra, sem ter feito as coisas que queria. Estava decidido. E pronto!” (Idem, p. 150). Em meio ao som de um programa de rádio, Meu coração Sertanejo, disseminando os "valores locais", as galinhas cantando, cachorros latindo, bois berrando, porcos a grunhir e passarinhos a pipilar (2005b, p. 149), admirando a flâmula desbotada do Vasco na parede, avista "as piscinas inatingíveis do Clube do Remo, moças e rapazes se divertindo, invejou-os" (2005b, p. 165).

Achando Cataguases pequena demais para o seu talento, empenha os móveis da casa e segue escondido da esposa para o Rio de Janeiro para tentar a vida como cantor. No ônibus, “Ê meu povo, vou embora, adeus!”. Embora temeroso, no meio da escuridão, seguiu no ônibus que engolia o asfalto (2005b, p. 169). Dele, não se tem mais notícias. É mais um engolido pela cidade grande.

O Beco do Zé Pinto, local que concentra grande parte dos desacorçoados que ficam na cidade, já havia aparecido em Mamma son tanto Felice, de maneira tímida, nos episódios "O alemão e a puria" e "O segredo". Neste segundo volume, o local também aparece como cenário de diversos capítulos, mas é em "Um outro mundo" que a história deste lugar é contada mais detalhadamente, tendo o seu desdobramento em "Vertigem", último episódio de $O$ mundo inimigo (2005b). 
À semelhança de João Romão, n’ O Cortiço, de Aloísio Azevedo, Seu Zé Pinto após anos de trabalho na fábrica, consegue construir casa a casa o beco que administra. Em princípio, as histórias nele ambientadas, apesar da miséria dominante, remetem a uma certa "camaradagem horizontal"18 entre vizinhos, como certa madrugada em "O alemão e a puria", em que a chuva inundou o beco sorrateira. Os moradores mal tem tempo de salvar alguns poucos pertences para refugiarem-se na rua. Na confusão, “Cadê a Dusanjos?", lavadeira cujo marido estava desaparecido, que resistia a deixar o local, tamanho desânimo. Ainda assim,

o Zito Pereira e o Presidente enfiaram-se na água imunda, deram de cara com a porta cerrada, Dusanjos, ô Dusanjos!, encontraram ela de pé em cima da cama, fora de si, o José Baptista no colo, Dusanjos, vamos sair rápido!, Me deixa, quero morrer!, Pega o menino, Presidente, eu levo ela, o Zito Pereira agarrou a mulher, ela se debateu, esmurrou, unhou-o, Me larga, me larga! (2005b, p. 116).

Ou ainda no episódio "O Ataque", do terceiro volume, que narra a tristeza de uma mãe de família ao se mudar do Beco, onde vivera de aluguel por cerca de 20 anos para uma casa própria, no Paraíso, bairro em que as moradias eram “salteadas, envergonhadas umas das outras". Diz a personagem

\begin{abstract}
Verdade, as enchentes que estragavam com tudo - 'perdi a conta de quantos colchões jogados fora - ficariam para trás, mas até disso, tinha certeza, sentiria saudade, até disso; e mesmo aquela camaradagem de parede-meia, espirro-saúde [...] E as brigas, as confusões, os disse-me-disse, a mexericagem...formavam uma família, afinal: a cara, a coroa (2006, p. $55-56)$.
\end{abstract}

Com o passar dos anos, a camaradagem entre os vizinhos vai dando lugar a inimizades e violência. Movido pela ganância, Zé Pinto aluga casas insalubres, sempre disposto a despejar a qualquer momento aquele que deixasse o pagamento pendente, "muita família que nem debaixo da ponte poderia se refugiar, tão pobre" "Não pagou? Rua! Não podia ter coração mole" (2005b, p. 175), pensava. Senão, se "bobeasse logo logo aquilo virava uma favela, um muquifo" (Idem, p. 177), como acaba virando.

\footnotetext{
${ }^{18}$ Termo cunhado por Benedict Anderson, em Comunidades Imaginadas, para definir um sentimento de "irmandade" entre os membros de uma nação.
} 
O tempo faz "o nível” dos inquilinos do Beco cair muito, pensava Seu Zé. Em vez dos operários de outrora, por lá só vivia muita "gente desgarrada", "sem eira nem beira" ou "desqualificada", quando começam a surgir sinais típicos de um crescimento desordenado da cidade

\begin{abstract}
Antes, a lei comandava. Não pagou o mês?, descia revolvão na cintura, bem à mostra, tirava o zé-mané no muque. Agora, a coisa se resolve com a polícia. Trata os soldados a pão-de-ló, precisa deles. Tem confusão? Chama a radiopatrulha. Eles vêm e ameaçam. Despejo é muito complicado. Tem que ter doutor adevogado [...] as casas estão caindo aos pedaços, sim. Telhas rachadas. Reboco lascado. Piso desdentado. E a imundice? O mau cheiro percebe-se da rua. Mas, o que fazer? Está velho, não tem forças (Idem, p. 178).
\end{abstract}

Acompanham o crescimento da cidade e do beco o tráfico de drogas, a violência, a miséria e degradação tanto das casas, agora caindo aos pedaços, quanto o convívio entre vizinhos, agora desconhecidos. A relação inquilino / senhorio, por sua vez reproduz a dependência que os trabalhadores recém livres estabeleciam com os coronéis durante a República Velha.

Apesar de receberem salários, seus ordenados ficavam comprometidos com os gastos no botequim, também de propriedade de Seu Zé Pinto, de modo que os moradores não conseguem sanar as dívidas e mantêm-se presos ao local. Além disso, Zé Pinto atua ainda como agiota, emprestando para os inquilinos pagarem o aluguel e a caderneta do botequim, num círculo vicioso de dívidas e ruínas. Como garantia, pegava relógios, anéis e medalhas, porta-retratos, pares de sapato, móveis. Já os encostados ofereciam o carnê do INPS, trocando "o canhoto por dinheiro, já devidamente descontados os juros” (Idem, p. 181).

A decadência dos moradores e das casas do beco contrastam com a vida de conforto e as benesses do progresso usufruídas por Seu Zé Pinto, o primeiro na rua a ter geladeira, televisão, "uma coisa tão importante que a janela ficava suja de gente espiando", telefone, que "até serviu para ganhar um dinheirinho extra, cobrando pelos recados que recebia e enviava”, fogão-a-gás, enceradeira, vespa, "um luxo!" Mas, "para conquistar esses confortos todos, haja tino! E tutano" (Idem, p. 181), inchava-se.

O último episódio de $O$ mundo inimigo, "Vertigem", remete tanto ao estado de sonolência e desfalecimento do protagonista, o cansado Seu Amaro, quanto ao 
crescimento desordenado de Cataguases. Depois de ter deixado à terra natal, suas visitas tornam-se cada vez mais esporádicas, diluindo-se "com o passar dos aniversários" (Idem, p. 189). E a cada vinda uma surpresa. A lembrança do passado pacato, cheiro de capim serenado, "mel das matas, lenha esfumando em café, em caldeirão de feijão, mugidos longínquos, ê boi! Ê boi!” são logo apagadas pelo novo cenário.

A antiga estação ferroviária, desativada. As carroças de aluguel, o cheiro de mijo de cavalo, o trem cortando a cidade como uma cobra levando minério-deferro para fora do Brasil, agora abrem espaço para carros que ziguezagueiam, buzinas, camelôs apregoando contrabandos, caixeiros e toda a sorte de barulhos típicos de uma cidade de médio porte (Idem, p. 190).

Mais uma vez a urbanização não se faz acompanhar da infraestrutura necessária, de modo que a cidade se transforma num "mundaréu de casebres, amianto escorando paredes costelas à mostra, folhas de alumínio acobertando chapiscos de cimento, ruas descalças, recortadas em veios de esgoto" (Idem, p. 191). O Beco do Zé Pinto, outrora bem conservado, chega a causar náusea, tamanho "o fedor que parecia emanar do chão, como se num pântano de bosta [...] meninos e meninas tímidos, catarro escorrendo de narizes feridos, frangalhos de roupas, dois vira-latas perebas à mostra e frenéticos rabos sujos afugentando mosquitos" (Idem, p. 192).

Paralelamente ao crescimento desordenado da cidade, aqui entendida como metonímia do país, corre o brutal envelhecimento das personagens mais velhas, os antigos guardiães da memória coletiva. Seu Amaro, "as rugas que redesenham o rosto, a pele flácida e ressecada que escorre pelo corpo, os brancos cabelos que apodrecem no travesseiro, o pinto mole, que já para nada serve” (2005b, p. 191). D. Margarida, seu amor da adolescência, internada em Juiz de Fora. "Cada vez volta pior...Não fala coisa com coisa...Mija pela casa inteira...Fica pelada aqui do lado de fora...Faz coco em qualquer lugar...chora sem motivo..." (Idem, p. 199). Seu Zé Pinto encontra-se numa cadeira de rodas, abandonado a um canto, "móvel sem utilidade" (Idem, p. 192). Um contraparente avisa que estão só esperando a sua morte para derrubar as casas do beco, um dos poucos resquícios da memória da cidade. 
Não sei na época do senhor, outros tempos, mas agora é só marginal...barra-pesada...até na polícia metem medo...Eu é que não enfrento os caras! Gente que não tem nada a perder...Mas eu sou casado, mulher, filhos...Se quiser, depois a gente volta lá, o senhor vai ver, uma miséria só, tudo caindo aos pedaços (Idem, p. 193).

Em meio ao crescimento caótico da pequena cidade mineira e ao apagamento de sua memória, tanto física - com a destruição das casas e a desativação da Estação do trem-, quanto humana - uma vez que os antigos guardiães do passado vão partindo para os grandes centros, sanatórios ou mesmo morrendo, - sobre essas ruínas e putrefação -, "urubus transvoam em concêntricas buscas" (Idem, p. 198). Este segundo romance, faz valer a observação de Ruffato de que no Brasil "pulamos da roça para a periferia decadente sem escalas" (2010, p. 322).

\subsection{Vista parcial da noite: lados de um mesmo Brasil}

O terceiro volume de Inferno provisório, Vista parcial da noite (2006), dividido em 11 capítulos, prossegue na sua tentativa de reavivar a memória que se vai esvaecendo, conjugando elementos que ajudam a compor uma visão parcial de Brasil. O romance insinua uma alegria superficial de Carnaval e de peladas de futebol, mas que são impreterivelmente abafadas por feridas nacionais e particulares mais graves e marcantes, como a ditadura militar, ou os problemas de alcoolismo e violência doméstica.

Como sugere a epígrafe de Ferreira Gullar, a narrativa representa um duplo espelho: "Flore um lado de mim? Do outro, ao contrário, de silêncio em silêncio me apodreço". De um lado, os sonhos e delírios de uma classe baixa a desejar outra vida. De outro, o calado apodrecimento das personagens que vivem na pequena cidade mineira, que neste volume se expande para a periferia rumo ao bairro do Paraíso.

O Paraíso de Inferno provisório nada tem de edênico. Pelo contrário, aqui as diferenças sociais ficam patentes. O local "ainda banguelo", distante das fábricas, é desassistido de infraestrutura primordial: "nem água, nem força, calçamento, 
então!, e escola?!". Nada disso é oferecido aos trabalhadores que por ali se instalam. Casebres de pau a pique e vira-latas constituem a paisagem do Paraíso dos pobres. Casas de alvenaria, poços artesianos e cachorros, compõem o Paraíso dos remediados; e chácaras de muitos pomares, pastores alemães e amplas varandas, por fim, formam o Paraíso dos ricos (RUFFATO, 2006, v.3, p. 105).

O romance oscila pois entre o sonho de uma vida melhor e uma realidade injusta e cruel degradada desde a origem. O lado sonhador é representado pelas jovens Mirtes, de "O ataque" e Teresinha, de "A homenagem". Esta última, leitora das revistas de fotonovela Sétimo Céu, Capricho e Grande Hotel, sucesso nos anos 1960 e 70, e que deseja uma vida mais glamorosa, por exemplo, uma festa de debutantes no Clube Social, trajando um vestido de "cetim branco rodado estrelado de lantejoulas aperoladas decote-princesa, luvas e tiara, salto alto e bolsinha-de-mão" (RUFFATO, 2006, p. 21). A mãe, D. Fátima, embora não consiga proporcionar o que a filha anseia, consegue com muito custo, após madrugadas viradas no ta-ta-tá da máquina de costura, aceitando até remendos, preparar uma surpresa em casa do tamanho do seu bolso.

$\mathrm{Na}$ "tarde aniversária" (RUFFATO, 2006, p. 22), embalada pelas vozes de Nelson Gonçalves, Miltinho, Orlando Silva, Francisco Carlos e Anísio Silva, o bolo assentado num tabuleiro forrado em papel alumínio, com saia de papel crepom enfeitada por balas de coco enroladas em branco, azul e rosa, tudo corria bem. Mais eis que ressurge o lado indesejado do espelho, quando o endemoniado Zé Bundinha, aos palavrões, expulsa os convidados sem mais nem porque, acabando com a pouca alegria que resta, reforçando a bandeira da denúncia de Ruffato sobre a questão do alcoolismo e da violência doméstica que rege boa parte das residências brasileiras.

Todo o mundo para fora! E principiando uma discussão com a Teresinha, Pára, pai!, o senhor está bêbado! Olha como você fala comigo, menina! Bêbado, sim, pai, bêbado! Essa casa é minha! Eu que mando aqui! Todo mundo para fora! Todo o mundo para fora! Calma, seu Zé, está tudo bem, o pessoal já ia indo...Se mete não! Eu é que mando nessa merda dessa casa! Todo mundo pra fora! (Idem, p. 64). 
A tecelã Mirtes de "O ataque", cuja idade regula com a de Teresinha, sonhava encontrar "um rapaz que pudesse soerguê-la da condição de operária para a de grã-fina" (Idem, p. 57), mas a realidade acaba sempre por pesar mais na balança, mostrando quase sempre o seu aspecto mais vil. D. Eni, sua mãe, é presenteada pelo marido e os pelos filhos com uma televisão Telefunken 23 polegadas, para acompanhar a novela. "Um descanso para a cabeça" e "para as suas pernas encipoadas de varizes" (Idem, p. 56). Mas a felicidade dura pouco. O ano é 1972, auge da ditadura militar no país, que aqui aparece sob a ótica da revolução dos militares, mantenedores da ordem e do progresso excludentes. A falta de estudo e informação das personagens faz com que elas aceitem e se conformem com o discurso do poder então vigente.

Quando o caçula da família cisma ter ouvido na rádio BBC que Cataguases seria bombardeada pelos alemães, Seu Sebastião, o patriarca, sai assustado em périplo pela cidade para alertar as autoridades. O prefeito dizia que o menino tinha problema de saúde; o vereador embora achasse tudo um absurdo, garantia levar o assunto para a pauta da Câmara. O padre dizia ser imaginação do menino; Seu Zé Pinto aconselhava uma coça bem dada. O diretor da escola, explica que desde que acabara a Segunda Guerra Mundial, em 1945, os alemães nem forças armadas tinham mais e aconselha encaminhamento psiquiátrico. Já o delegado Aníbal Resende, temia que o menino quisesse implantar o terror no país:

\begin{abstract}
deixe-me explicar uma coisa para o senhor: o senhor, a sua família, são pessoas de bem, conhecidos, ordeiros, cumpridores do dever, todo mundo sabe...Agora o senhor já ouviu falar dos comunistas? (didático) Existe em nosso país gente que quer implantar o terror, irmão matando irmão [...] onde os valores cristãos de nada valem, onde os homens dividem as mulheres com os amigos, as filhas dormem com os pais, os padres são enforcados por pura diversão, onde não há lei, onde reinam a anarquia, a bagunça, a perdição...(gritando) São esses comunistas, seu Sebastião, que divulgam notícias como a que o senhor anda espalhando, com o objetivo de provocar o pânico, a desordem, a desconfiança...(esmurra a mesa) (Idem, p. 66).
\end{abstract}

Autoritário, o delegado decide confiscar os aparelhos de rádio e televisão da casa. Sentada na sala, resignada, D. Eni bordava uma toalha que cobria a mesinha onde "há pouco, lembra?, pousava a televisão, a nossa televisão, que nem tínhamos acabado de pagar ainda" (Idem, p. 68). À perda da Tv, segue-se ao 
diagnóstico da esquizofrenia do filho e os vizinhos a evitá-la. "Havíamos vislumbrado um dia a felicidade?" (Ibidem), lamenta-se, restando-lhe apenas o apodrecimento mesquinho.

A repressão militar é também pano de fundo do episódio "O morto", que gira em torno do estranho assassinato de Permínio Pedroso Alves, proprietário de um circo instalado em Cataguases. O homem que levava uma vida cigana "beijaflorando cidades" (Idem, p. 134), tem seus sonhos interrompidos, quando cai nas garras do mesmo autoritário e moralista delegado Aníbal Resende, que se julgava responsável pela ordem na cidade: "Não fosse o seu zelo", pensava, "as repartições das fábricas se converteriam em antros revoltosos". Truculento e brutal impunha a seu modo a sua autoridade: "Pisão de galinha não mata os pintos" (Idem, p. 139), boquejava.

O sindicalista Zé Rosa, por exemplo, que outrora fomentara "badernas, greves, piquetes, manifestações" (Ibidem), estava agora, preso na Penitenciária de Linhares em Juiz de Fora, orgulhava-se o delegado. Respaldado por máximas como "a cobra mata-se pela cabeça" ou "uma laranja podre corrompe todo o resto", Aníbal procura impor uma ordem repressora e machista à cidade. Dizia ele,

\footnotetext{
o mundo tresanda porque escasseiam os machos, errou, tem de pagar, está na bíblia, por conta da rédea solta, filho desrespeita pai, filha debocha da mãe [...] sicrano mijou pra trás?, porrada nele, assim aprende a apreciar autoridade (RUFFATO, 2006, p. 132)
}

Tanto Aníbal quanto seus subalternos tinham como praxe esculachar os presos da cidade. $\mathrm{O}$ soldado Carneiro tinha uma afeição especial pela tarefa: exceto quando o "elemento" fosse filho de alguma autoridade importante e o intimidasse com o arrogante ritual de afastamento: "Sabe com quem está falando?, então procura se inteirar, negão, sou filho do doutor-fulano-de-tal e fodo com você se me encher o saco" (Idem, p. 133).

A frase, como observa o sociólogo Roberto da Matta em Carnavais, malandros e heróis, não é uma mania ou modismo passageiro na cultura nacional, mas uma "forma socialmente estabelecida" que funciona como um rito de separação quando alguém se sente 'ameaçado' e aposta em inferiorizar o status 
social alheio (1997, p. 187). Intimidado e sem perder a noção de "seu lugar social", Carneiro descontava então em "ladrões de galinha, maconheiros pés rapados, bichas loucas, mulheres-da-vida" (Idem, p. 133).

O dono do circo almejava deixar a profissão, cansado da vida cigana e de dar murro em ponta de faca, afinal, estavam vivendo tempos difíceis, sendo trocados ora por circos internacionais, ora pela televisão (como aparece no filme Bye, bye Brasil (1979), de Cacá Diegues, que narra a trajetória de uma trupe que corre o Brasil cidade em cidade, procurando evitar àquelas apinhadas de antenas de TV, concorrentes número 1 da trupe). Mas antes disso é chamado à delegacia para explicar suas intenções na cidade.

Desconfiado de que Permínio pudesse ser 'agente subversivo', Aníbal pede que ele encene na própria delegacia o monólogo que costumava representar no circo. "O senhor tem que me mostrar isso antes! Precisa passar por mim!", censura (Idem, p. 140). Pouco depois, misteriosamente, como nos tempos de ditadura militar, o jornal local anuncia o assassinato forjado do dono do circo, encontrado morto com uma punhalada. O criminoso, segundo a notícia de jornal, teria sido um desempregado que queria assistir ao espetáculo sem pagar e que tendo sido "interpelado pela vítima, reagiu incontinenti com violência", registra a coluna "Ronda Policial" (Idem, p.141), sugerindo que o crime não passa de uma armação do poder como forma de acobertar o apagamento do 'subversivo' circense.

O lado podre do espelho é também narrado nos episódios "Vicente Cambota", a ser comentado adiante, e "O profundo silêncio das manhãs de domingo". Abandonado pela mulher, o violento Baiano, protagonista deste episódio, sobrevivia de bicos e biscates, vivendo com os quatro filhos num barraco também no Paraíso. Já no primeiro parágrafo, atinge com um chute nos "baixios" as costelas de Rex, um cachorro magro que insistia por um afago do dono. "Magoado, o cachorro, nem um resmungo, refugiou-se num canto do terreiro, borrado pela névoa branca que cobria o mundo" (2006, p. 79).

A tradição de maus tratos e espancamentos, vem de longa data, na trajetória de Baiano. O pai, Seu Chicão, homem "ignorante, bronco, enfezado", com o intuito de emendar o filho, caçava-o pelos desvãos da cidade, e para cada deslize 
de criança, uma reação mais e mais bruta: se o flagrava pegando passarinho, alçapão e gaiola destruídos; jogando bilosca a valer, castigo de grão-de-milho; nadando no Rio Pomba, cascudos; brigando na rua, safanões; sapeando jogo-debaralho, puxão-de-orelha; baforando cigarro, beliscões na bunda e nos braços; folheando revista de-mulher-pelada, pescoções; em servergonhice no pasto, relho na cacunda; bandeando em más companhias, chutes à mancheia; frequentando mulher da Ilha, murros onde pegasse (Idem, p. 82).

Expulso de casa pelo pai alcoolizado, sonha com a vida no Rio de Janeiro, levando apenas uma sacola de papelão, imaginando devorar o mundo: “ah, o mar! As praias! Os edifícios! As luzes! O cristo-redentor!”. Mas, de recomendação em recomendação, afasta-se da cidade cartão postal, conseguindo serviço numa oficina de conserto de bicicletas em Bangu, "calor dos infernos, sete meses fedendo a óleo" (Idem; 81) até voltar para Cataguases. Enrabichado pela cachaça, vivendo de bicos, deixado pela esposa e sem esperanças, decide pôr fim a sua dor, submergindo no rio Pomba, com o filho Claudio, no profundo silêncio de uma manhã de domingo.

O sonho de Lalado, protagonista de "Roupas no varal", é também obcecado pelo desejo de consumir. A conquista de um emprego como motorista do Armazém do Lino, lhe permitiria, em suas elucubrações, além de "desfilar para baixo e para cima entregando compras" numa Kombi azul 1200, em cujo vidro traseiro estava colado um dos lemas da ditadura militar, "Brasil, ame-o ou deixeo", a possibilidade de trocar a sua Monark por uma vespa "ou quem sabe até mesmo por um Fusquinha, por que não?” (2006, p. 95). Num final de sábado qualquer, Lalado parte para a entrega de uma última encomenda de Brahmas, cachaças, groselha e mortadela numa casa de tolerância. Dentre calcinhas e vestidos esticados no varal, nota uma moça sentada fumando, "pretíssimos cabelos escorridos, fugazes olhos esgazeados, visagem”. Quase riu para a moça mas, lembrou-se: ela havia sido sua colega no grupo escolar

Não tem jeito não essa menina! Então a professora aproximou-se e espatifou a régua-demadeira em sua cabeça Dona Cristina, eu não...vestido-salopete azul, camisa tergal branca, sapato boneca Diolinda, chora não, boba! Diolinda...Diolinda fe-de! A Diolinda fe-de!" (RUFFATO, 2006, p. 100) 
A prostituição aparece aqui como a única saída para a vida de desgraça, miséria e violência comuns a Diolinda, Cidinha (de "Paisagem sem história", v. 2) e Valdira ("Um outro mundo", v. 2). Tal qual as "moças de família" Mirtes e Terezinha, essas "moças da vida" também tinham os seus sonhos de meninas, também eram leitoras das revistas Amiga, Contigo e Sétimo Céu, cujas fotos de atores e cantores foram cuidadosamente recortadas e coladas para forrar as paredes internas de seus armários. Porém, seja pela completa falta de estrutura familiar, financeira ou emocional, algumas desilusões após, são levadas a encarar a vida de forma mais desafiadora, simulando um despojamento, um "esgar debochado de quem se acostumou [...] a revolver, paciente, ruga por ruga, as horas intermináveis da Ilha ${ }^{19,}$ (2005b, p. 128).

Intercalam-se aos maus tratos, a perda da dignidade e o escoamento de almas para os grandes centros, os dias de euforia. "A Homenagem" já havia narrado um cambaleante baile de Carnaval no Clube do Remo, onde a balbúrdia de índios, colombinas, melindrosas, políticos e pierrôs ao som de Alá-la-ô e tantas outras marchinhas abafavam o barulho dos teares da Industrial. Já o episódio "Cicatrizes" ensaia uma nova trégua, narrando, uma outra história de futebol, também em 1970, porém, menos glamourosa que a da conquista da taça Jules Rimet pela seleção brasileira. Trata-se de um relato da fundação e glória do efêmero Botafogo Futebol Clube de Cataguases, o 'botafoguinho'. Seu Miguel sobrevivera com sua esposa, D. Creusa, e os oito filhos até o momento fazendo frete como carroceiro na Praça da Estação. Agora, desativado o trem, vive, como muitos personagens, desacorçoado ferventando na cabeça "a ganhação do dia" (RUFFATO, 2006, p. 106). Para distrair, decide com o filho Paco, que "corria atrás da bola sol a sol", criar um time de futebol. "Cataguases tem Flamengo; Vasco, do Leonardo; América, da Granjaria. E, agora, também haverá Botafogo, do Paraíso!” (Idem, p.111).

Do vereador, do médico e do bicheiro da cidade, vieram a ajuda para a compra do uniforme. O time é arregimentado no boca-a-boca, "gente moradora de ali-por-perto" (Idem, p.111). Partidas vieram e vitórias. De começo tímidas, vão

\footnotetext{
${ }^{19}$ Zona de prostituição da Cataguases ficcional.
} 
ganhando fama pela cidade, atraindo vendedores de laranja, de garapa, de picolé, de algodão-doce, de pipoca, que arrodeavam as laterais (Idem, p.112). Reputado o time, veio o desafio intermunicipal em Recreio. Transitariam pela Rio-Bahia, "gente ali havia que nem sequer Leopoldina conhecia" (Ibidem).

Às onze horas, em plena euforia, encostou junto ao meio-fio do bar do Auzílio, "a charanga surdo-repinique-tamborim-zabumba-pandeiro-apito choramingando por favor, vai embora, / minha alma que chora...” (Idem, p. 113). Atrás da festança, esgotados os garrafões na farra do sangue de boi e os barris de cachaça curtida, estourados os foguetes, que amenizariam o desconsolo que consome os dias das personagens da saga, no final do domingo o time retorna fatigado para a realidade de suas intermináveis labutas.

Finalizando o romance, o episódio "Haveres", assim como os contos "O Segredo" e "Vertigem", que encerram respectivamente Mamma son tanto Felice (2005) e $O$ mundo inimigo (2005), se dedica a representar a decadência e o estado de abandono do cenário principal onde as narrativas são encenadas. Se "O segredo" narra a decadência e o abandono da zona rural de Cataguases, palco do primeiro volume de Inferno provisório, e "Vertigem" chama a atenção para a deterioração do Beco do Zé Pinto, local onde predominam as narrativas do segundo volume da saga, "Haveres" vai chamar a atenção para o esgotamento de mais uma paisagem, o bairro do Paraíso, região de início considerada banguela, com casas salteadas, mas agora uma "imundice de meninos e bicicletas e bolas e brigas, balbúrdia de música” (2006, p. 145).

“Tão diferentes os tempos” (Idem, 147), especulava D. Juventina. Se antes a porta da cozinha vivia encostada para quem quisesse entrar e a janela aberta por conta do calor, agora pegara o hábito de trancar tudo. Certo dia, pela janela aberta entrou um rapazinho, que apareceu "na cabeceira apontando um chuço" e roubou os seus "haveres". Levou uns trocados de sua aposentadoria, o rádio-de-pilha, o despertador, o cordão-de-ouro com pingente de Nossa Senhora do Carmo. Seriam "uns-dali-mesmo, enredados no tóxico" (Idem, p. 146-7). "O que será dessa juventude, meu deus?", aflige-se (2006, p.147).

Com o passar dos anos vão-se as forças: já não tem energia para "bassourar as cantos do teto, pôr roupa para quarar, vasilhas para secar ao sol, pregar um 
botão, remendar uma peça" (2006, p. 145-46). Vão-se também os filhos: Cléber, estoquista da Volks, em São Bernardo do Campo); Verônica vive de bico em bufês em São Paulo e Cassiana, "desafiadora em suas indecentes minissaias" (Idem, p. 153), em Brasília. De quando em quando, ligam, mas não vêm mais vêla. Magras notícias chegam em mínimas cartas, cerimoniosas ligações de aniversário; sempre um compromisso mais urgente.

$\mathrm{Na}$ chamada modernização vencem mais uma vez, em Vista parcial da noite, o esgarçamentos das famílias, a solidão, a escalada da violência, a ruína. Neste romance, Luiz Ruffato aprofunda um pouco mais a sua visão de uma sociedade operária de "pés atolados", em que o clima de religiosidade e de poucas letras se mistura com cenas de pais espancando os filhos que não cumprem aquilo que lhes é deles esperado.

\subsection{O Brasil urbano}

Urbanizamo-nos, não há dúvidas. Nada deixamos a dever ao padrão de sociabilidade predatória e excludente de primeiro mundo (HOSSNE, 2002, p. 32)

O livro das impossibilidades (2008), quarto volume da série, já não gira em torno da escolha de Sofia que perpassa a saga até aqui: ficar em Cataguases com o sentimento amargo da covardia e do fracasso, numa cidade sem horizontes, ou deixar a cidade com a coragem e a necessidade de buscar algo melhor. A vida no interior já é ponto vencido e a lembrança de almoços sossegados, "mastigando o arroz-feijão-angu-verdura-pedacinho-de-carne", ao som do córrego "chuáááá" e do "zuuumm-zuuumm dos mosquitos", à sombra de uma árvore, quando o "mundo desexistia" (2008, p. 22) é passado remoto, nas três histórias que compõem o quarto volume: "Era uma vez", "Carta a uma jovem senhora” e "Zezé \& Dinim”. Quem tinha que partir, já se foi. Quem ficou, vive uma vida pacata e mesquinha. A partir daqui fica consolidada a dispersão.

Ainda que o romance aponte a cidade grande como única possibilidade de "crescer", ele também aborda as dificuldades e frustrações dos que emigram para 
os grandes centros, fazendo coro ao tema já abordado em Eles eram muitos cavalos, de 2001. A cidade ilimitada, caótica, descontínua, onde predomina o contraste e a exclusão, formando um conjunto fraturado e desmantelado, constitui também o cenário deste quarto volume de Inferno provisório

Sacos de lixo sitiam calçadas esburacadas

Bicicletas-de-carga

Recostados em camburões fardas alardeiam fuzis revólveres

Cassetetes

Mendigas mãos misericordiam misérias

Urgentes baratas desviam-se afobadas

Casas botequins edifícios lanchonetes bancas de jornais bares ambulantes uma hora e meia escoa pés enregelados (Idem, p. 48).

$\mathrm{Na}$ cidade que agora abriga 'retirantes' vindos das diversas regiões do país, repleta de não-cidadãos anônimos, predomina a desigualdade. O novo quadro seria, para Andrea Saad Hossne, resultado de um projeto malfadado de modernização, nos moldes da economia liberal e, mais recentemente neoliberal, baseado numa concepção de progresso que passa pelas agruras de uma urbanização que segrega e exclui (2007, p. 19). Ainda de acordo com a autora, desde a abolição da escravatura e da implantação do modelo liberal europeu, "o Brasil vem passando, aos trancos, barrancos e barricadas" por um modelo de modernização que tem na urbanização não apenas a criação das cidades, mas também um padrão de civilidade que resulta na concentração de renda e na bárbara exclusão social (2007, p. 21).

A metrópole em O livro das impossibilidades (2007) aparece como o local do desenraizamento, da exploração e da solidão de sujeitos à deriva, de "sobreviventes" que vivem fechados em seus cotidianos muitas vezes cinzentos, presos a dramas corriqueiros, sem heroísmos, e a subjetividades esfaceladas. O romance revela aspectos distópicos de um espaço urbano desencantado, numa realidade feita de relações precárias, violência e medo. Ou como afirma José 
Nêumane, a respeito de Eles eram muitos cavalos, mas que se aplica também aos dois últimos romances da saga, representam "um caos urbano e humano que se acotovela, se ama, se detesta, ou simplesmente, na maior parte das vezes, se ignora, no segundo maior conglomerado urbano do planeta (Estado de S. Paulo, 06/01/2002).

"Era uma vez" narra a história de uma família despedaçada, que vive "novos tempos" na cidade grande em meados dos anos 1970. A emancipação da mulher e a total ruptura com os elementos da vida interiorana marcam a narrativa. $\mathrm{O}$ episódio gira em torno de Nelly, mulher "moderna e independente" que sustenta a família - mãe, pai e os dois filhos, Nílson e Natália - em São Paulo, mas que é criticada pelos conterrâneos por ter modos demasiadamente avançados, por usar calças compridas ou fumar em público, “onde já se viu?” (2008, p. 35), questionavam. Ao deixar para trás, "a sulfa da inveja" que corrói "as tardes sufocantes das amigas encurraladas na fiação ou na tecelagem das fábricas de Cataguases” (2008, p. 17) para se casar com Dimas é tida como afortunada.

\begin{abstract}
Uma loteria inteira de sorte, pois corria que o danado escriturava numa química ou mandava numa química ou sabe-lá-o-quê numa química (era uma química?)...enfim, um tipo bem situado, aocontrariamente dos pés-rapados que sussurravam indecências nas suas orelhas, dos desinfelizes que pegavam às seis e mastigavam a marmita mirrada de cachorro escorraçado, tristeza, meu deus, saber que nunca desencantariam daquela sengraceza. Suspiravam pela Nelly, que, engarupada no Dimas, sem virar para trás, embrenhou-se entre carros e edifícios e gentes, benzida pela garoa de São Paulo, ê São Paulo (2008, p. 18)
\end{abstract}

Isso é o que sonhavam as amigas, pois o marido de Nelly era "um pobrecoitado habitante de um pardieiro na Saúde”, plantado num lote com prestações atrasadas. "Um melancólico que em emprego algum ancorava, abatido, desanimado, desacorçoado, varando as horas enroscado num sofá velho, inútil como a folhinha dois anos passada" (2008, p. 18).

Depois de revolver a cidade, estranha e confusa em busca de colocação, quando já espocavam calos nos pés, "gasta a sandália de muitas jornadas”, Nelly consegue empregar-se como faxineira no Hospital Santa Cruz. Batalhadora, comprou geladeira, pôs taco no chão, pintou as paredes...engravidou, trouxe os 
pais para perto. "Sentou a bunda na carteira de uma escola noturna, fez-se auxiliar de enfermagem. Afundou nos livros, acabou enfermeira" (2008, p. 19).

A filha Natália, segue os seus passos. É tida como metida, barulhenta, debochada, mandona e sarcástica, em contraste com o primo Guto, de Cataguases, que vem passar uns dias na casa dos parentes em São Paulo. Envergonhado, "avoado", "desengonçado", "tímido", "frágil”, o “caipira' que veste "roupas limpas e asseadas, mas desconformes ao tempo, ao ambiente" (2008, p. 27) é subjugado pelos primos cosmopolitas. O seu "quichute", a "calça de escritório", a origem do interior, tudo é motivo de gozação para os meninos da capital (Idem, p. 41), que vestem calça Lee e US Top e calçam tênis conga, curtem Deep Purple, Black Sabbath, The Who, Led Zeppelin e fotos de Betty Saddy nua. Zombado por todos, ao tomar uns goles de cachaça, desabafa:

\footnotetext{
- "Natália...vocês tudo...vocês me acham um bosta, né?

- Quê?!

- Vocês tudo...você...seu irmão...sua mãe...seu namorado...vocês tudo...

- Ah, Guto, dá um tempo...

- ...mas...Natália, ó...sou um bosta não...(2008, p. 57)
}

Assim, a vida na metrópole escorre entre pratos colorex âmbar, garfos, guardanapos, garrafas de Coca-cola família, que dividem as tardes de domingo com o Programa do Silvio Santos (Idem, p. 37), entremeados pela chegada incessante das "quase-vidas" que vagueiam entre carros, ônibus e fumaças na tumultuada cidade cinzenta e ainda pelo medo dos mais velhos de não serem enterrados na terra natal.

"Carta a uma jovem senhora", o segundo capítulo, é mais uma história que ajuda a compor a cartografia da ruptura com a cidade natal em nome da busca frustrada de melhores condições de vida nas metrópoles-purgatório entre os anos 80 e 90. "Mais dia, menos dia, a gente tem que tomar rumo...Não dá pra ficar aqui a vida inteira...No Rio pelo menos a gente tem mais...possibilidade...assim...de 
crescer...” (Idem, p. 71), dizia Aílton, protagonista do episódio, a Laura, sua paixão do passado.

De todos os amigos da adolescência, poucos restaram em Cataguases: Isaías é representante comercial no Espírito Santo; Ricardo, protético em Ubá; Vilma (companheira de Zezé, em “Zezé \& Dinim”, v. 4), cumpre pena por tráfico de drogas em Muriaé; Virgínia é professora de matemática em Cataguases; Pistolinha é engenheiro no Rio; Saulinho, nos Estados Unidos e Jacinto, namorado de Laura para desgosto de Aílton, deixara a cidade para servir à Marinha mercante, em Santos.

Tomado pela inveja de Jacinto, que viajaria o mundo, conheceria outras culturas e outras pessoas, Aílton deixa também Cataguases no rastro do amigo "sortudo" em busca de uma oportunidade melhor no Rio de Janeiro. Mas, nem só de encantos é a Cidade Maravilhosa encontrada pelo protagonista, que dividia um barraco com um colega no morro do Pavão / Pavãozinho, na rua Sá Ferreira, até ser demitido por conta de um "gerenciamento moderno...redução de custos...essas coisas" (RUFFATO, 2008, p. 73).

Em tempos de capitalismo globalizado e de uma modernização que não sustenta o emprego e a cidadania prometidos, o profissional que não tem como se adaptar à velocidade das mudanças e às atuais exigências da competitividade econômica é desqualificado e descartado. Na nova ordem mundial, "a questão do desemprego tende a se confundir com os azares de cada um", como alfineta Vera da Silva Telles, em “A 'nova questão social' brasileira” (1998, p. 115).

No período indicado por Ruffato no conto, anos 80-90, o desemprego nas áreas metropolitanas crescia assustadoramente, impulsionado por uma selvagem política de redução de custos e de modernização tecnológica posta em prática. Também o crescimento do trabalho autônomo, precário e com remuneração incerta e baixa, se acentua. Multiplica-se o número de camelôs, de vendedores ou pedintes situados nas esquinas das ruas de maior movimento das metrópoles, e o 'trabalho' associado à distribuição da droga e ao crime organizado.

João Manuel Cardoso de Mello e Fernando A. Novais, no ensaio "A que ponto chegamos", acreditam que, diante desse quadro, ficamos reféns da ditadura 
dos mercados, da venda do patrimônio público para pagar dívidas, do socorro aos bancos falidos, do corte de gastos sociais para equilibrar o orçamento, da usurpação dos direitos trabalhistas para aumentar a competitividade (CARDOSO, 1998, p. 12).

Para aumentar a onda de 'azar', nesse mesmo dia, Aílton é impedido de chegar a sua casa, cercada por camburões, sirenes histéricas, revólveres, fuzis e uma multidão espremida junto ao cordão de isolamento. Infiltra-se entre os curiosos e descobre que a polícia invadira o morro: "ninguém entra, ninguém sai" (Idem, p. 72). O romance vem fazer coro à representação do forte traço excludente da sociedade brasileira e sua "pátria mãe gentil" que põe crianças no mundo para correrem de camburão, cheirar cola em vez de ir para escola, ter medo de escopeta em vez de careta, como narra Gabriel Pensador, em "Pátria que me pariu" (1997).

De acordo com o jornalista Hugo Sukman, o ano de 1964 marca a transição da representação da cidade ainda linda e encantadora para um patético processo de brutalização que o país, a cidade e a música popular passariam a experimentar. A perplexidade diante do caos social é totalmente inversa ao idílio narrado na época clássica da MPB (definida pelo jornalista como o período entre 1920 a 1950). A partir de então, quem mora no morro, não vive exatamente pertinho do céu, onde tem alvorada e passarada, como nos versos de "Ave-Maria no morro" (1942), de Herivelto Martins. Agora fica patente a percepção de uma cidade essencialmente violenta. Tiros de escopeta, roubos, becos imundos, gravidezes indesejadas, tráfico de drogas passam a fazer parte tanto das letras de Chico Buarque (Estação derradeira, 1987), Aldir Blanc (Tiro de misericórdia, 1977) e Paulo César Pinheiro (Nome de favela, 2003), somente para citar alguns exemplos (2009, p. 99-101), quanto das histórias narradas por Luiz Ruffato em Inferno provisório.

Desolado com a perda do emprego, a falta de perspectiva na cidade grande, passados dezesseis anos, a ideia de voltar à Cataguases para "comer algodão" nas tecelagens locais tampouco agrada a Aílton. "Cataguases? Não, cara, de jeito nenhum...Tenho mais nada a ver com aquilo lá não...” (Idem, p. 73), diz para César o companheiro de barraco. Desde que saíra de lá, só voltara três vezes, todas elas para enterrar um parente. Por lá, “andava pelas ruas na esperança de 
encontrar, virando a esquina" um amigo. "Mas qual o quê. Nenhum rosto conhecido, nada do antigamente, nada" (Idem, p. 75).

Mas uma coisa não the sai da lembrança: a perda de Laura, a ascensão de Jacinto... Na tentativa de relembrar o seu passado, "recordar os velhos tempos, tentar recuperar alguma coisa" que nem sabe o que é para "poder começar tudo outra vez" (Idem, p. 80), decide ir atrás de Jacinto, em Santos. Encontra também uma cidade deteriorada com a chegada do progresso: perambula por "ruas ausentes de árvores, antigos sobrados desfigurados em imundos botequins, enfumaçadas salas de sinuca, duvidosos restaurantes, suspeitos quartos de aluguel", esbarrando nas calçadas com "humildes vira-latas hesitantes e tristes mulheres empetecadas no aguardo de fregueses estranhos e apressados" (Idem, p. $82)$.

Para sua grande surpresa, descobre Jacinto "magro, calvo, débil bigode, olhos ariscos entocados" por trás de um balcão de um botequim. "Você largou a Marinha?”, pergunta Aílton. Desajeitado, o amigo revela que nunca havia posto os pés num navio: “- Inventei...para impressionar Laura...vocês...Queria parecer importante...Não medi as consequências...” (Idem, p. 86).

Aílton projeta em Laura todo o apreço pelo passado: "com o tempo, descobri que na verdade eu não queria esquecer você, por que você é o meu passado e eu não queria perder o meu passado, única certeza que possuía” (Idem, p. 75), escreve em carta na tentativa de explicar tudo o que se passou nos últimos anos. Mas já é tarde. Nada restara do passado. Solto no mundo, Aílton já não tem para onde voltar. O seu passado não está mais em lugar nenhum. Com a partida, perdeu-se o "o fio da meada" (Idem, p. 80).

Se entre as décadas de 1950 e 1970 pairava entre os brasileiros uma sensação de que faltava dar alguns passos para finalmente nos tornarmos uma nação moderna, a história de Aílton mostra que esse otimismo vai mudando a sua forma. A impossibilidade de voltar ao passado somada a falta de perspectiva em relação ao futuro, só faz crescer a desesperança. Se durante um período relativamente longo, o presente nacional tinha sido melhor do que o passado, e o futuro prometia ser melhor do que o presente, na década de 1990, progressivamente, a ideia de um futuro de progresso individual vai se esfumando. 
Para João Emanuel Cardoso e Fernando A. Novais, a sociedade patina, nesse período, "não encontra saídas coletivas que restaurem o crescimento econômico acelerado e a mobilidade social ascendente. E as esperanças vão sendo frustradas uma a uma" (1998, p. 14).

Numa pensão em São Paulo, Aílton, desconsolado, na desesperança de refundar o seu passado, amassa as cartas que enviaria para Laura e rasga o seu endereço. Do lado de fora, a fumaça dos ônibus, caminhões, carros e motocicletas que congestionavam a Avenida São João, o barulho dos motores, o alarido das buzinas, a algazarra das vozes misturam-se a prostitutas, travestis, traficantes, meninos-de-rua espalhados por todos os lados, amordaçados e sufocados habitantes das metrópoles.

Por fim, em Domingos sem Deus (2011) o autor retoma narrativas de poucas, muito poucas conquistas, solidão, traições, filhos indesejados, um trabalho sem fim e a constante preocupação de alcançar o dia 30 com as dívidas pagas. Histórias de personagens que, como dizem os versos de Manuel Bandeira $^{20}$, epígrafe do volume, morrem tão completamente, que sequer deixam escritos os seus nomes, relegadas ao esquecimento. Aqui, Ruffato encaixa as últimas peças no seu trágico mosaico do proletariado brasileiro.

Antigo morador de Rodeiro, Seu Valdomiro, personagem de "Mirim", que agora vive em Diadema, recorda como o seu "momento mais arco-do-triunfo" o dia em que tirou um retrato para a formatura da quarta-série, em 1958, a única garantia de que existira um dia. Valdomiro deixara a cidade natal com pouco mais de 18 anos, com a "breve esperança de ajuntar dinheiro e candear os sonhos dos irmãos a uma vida melhor, casa de tijolo-e-laje e comida farta, roupa domingueira e cabeça levantada" (2011, p. 16). Arruma uma colocação na Conforja, a maior 'forjaria da América Latina', e, como era de se esperar, o contato com os parentes vai ficando cada vez mais esporádico. Num mês lhe falta dinheiro para voltar a Cataguases, no outro, coragem; num Natal, novos amigos, no outro, a família da namorada; num Ano Novo, Santos, no outro, plantão; num Carnaval, Rio de Janeiro, no outro, o batente; hora-extra em feriado prolongado e cansaço em

\footnotetext{
20 "Morrer tão completamente / Que um dia ao lerem o teu nome num papel / Perguntem: 'Quem foi?'... / Morrer mais completamente ainda, / - Sem deixar sequer esse nome.
} 
outros. Assim, “os anos fu!, evaporaram” (Idem, p. 19). Nas poucas vezes que retorna à cidade nota o bar do Pivatto no chão, a ausência do cheiro de mijo e bosta que empesteava as manhãs, a loja do Turco, a máquina-de-arroz. Nada restara do seu passado, somente a foto da quarta série.

"Sem remédio" narra a solidão de Ana Elisa, irmã de Gildo e Gilmar, personagens de $O$ mundo inimigo (2005b). Aos cinquenta anos, torna-se uma mulher "pânica", que vive a base de tranquilizantes na Grande São Paulo, com o marido Nenê e os três filhos. Muitos quilos acima do peso, acumulado durantes as gravidezes, os cabelos grisalhos, falhos, estragados, rugas, pés-de-galinha, estrias e celulites. Depois de anos de casamento descobre que o marido explosivo, intolerante, malcriado, enfezado e macambúzio andava agora com deus-e-o mundo. "O homem busca fora o que não possui no lar. Você precisa fazer um regime, esmagrecer, marcar salão de beleza, tratar o cabelo, se empetecar..." (Idem, p 32), dizia uma vizinha.

O mal-estar das primeiras histórias de Inferno provisório mantém-se intato neste último volume, somado aos esbarros, encontrões, tropeços e topadas da multidão estressada da megalópole que só fazem aumentar a solidão. Homens, vira-latas e gatos se estranham. As discussões diárias entre pai e mãe só fazem afastar os filhos. Angustiada, Ana Elisa tenta em vão dietas "fáceis" da lua e dos líquidos, simpatias esdrúxulas, cortes de cabelo, alisamentos...lingeries, e nada. Seu estado de abandono só é acalentado pelo silêncio da madrugada e os cinco Lorax diários. "Então, a urina quente escorregou coxas e panturrilhas" no metrô lotado. "O uniforme" (e não o segurança do metrô, destituído de nome, origem, pelagem, tais quais os cavalos de $O$ romanceiro da Inconfidência, de Cecília Meireles) aperta o seu antebraço, conduzindo-a devagar "em meio a pernas curiosas olhares indagativos desprezo zombaria Mijou ali ó Deve de ser louca Aquela lá risos passantes" (Idem, p. 24).

Certo dia, entre anônimos vagando pelo centro de São Paulo, uma verdadeira Babel bíblica, "longos cabelos como o comprimento da saia ofertaram um exemplar da Folha Universal no esbarra-esbarra do Vale do Anhangabaú" (Idem, p. 34). À noite abriu o jornal da igreja evangélica e encontrou em histórias paralelas, palavras que amenizavam suas dúvidas. Senão um remédio, ao menos 
um paliativo para a canga da solidão que pesa nas almas que vagueiam pelas metrópoles, como no documentário Viramundo (1965), de Geraldo Sarno.

Em vez dos mineiros de Ruffato, o documentário retrata a vinda diária de milhares e milhares de nordestinos para São Paulo em busca da riqueza paulistana, mas lá chegando, o que os aguarda é o desemprego e a caridade - como na música-tema de José Carlos Capinan - promovida pelas inúmeras religiões que procuram preencher o vazio deixado pelo rompimento com os laços familiares e comunitários. Bispos, protestantes, umbandistas prometem soluções e curas milagrosas numa cidade superpopulosa repleta de almas solitárias e cansadas.

O episódio "Trens" retoma a história de D. Nica, mãe de Carlos, protagonista de "Aquário" de Mamma son tanto Felice (2005). Revela uma Cataguases também de "outros tempos", superpopulosa, repleta de caminhões, carros, motos, casas operárias, comércio suburbano, botequins, açougues, padarias e mercadinhos "atabalhoados". "Quantas histórias por detrás de cada uma daquelas paredes! A pracinha, o Centro Espírita Bezerra de Menezes, o Beco do Zé Pinto, a Mercearia Brasil...paragens outras, distantes, remotas, longínquas..." (2008, p. 40). A vida de Nica desandara em amarguras. A morte rondava-a, "esfacelando os seus, mas caprichosamente preservando-a, como uma provação" (2008, p. 42). Um filho enterrado, outro perdido para o "mundo" - São Paulo -, uma filha "desajuizada" e outro biscateando relógios e despertadores numa banca de camelô perto da rodoviária. "Isso o que restara" (Idem, p. 42). A vida familiar se esfacela em nome da "comédia do progresso" (TELLES, 1998, p. 107).

"Milagres" é mais uma história de ruptura, esgarçamento e de necessidade de apagar o passado. O cenário do conto é uma borracharia 24 h à beira da estrada, próxima ao município de Milagres, na Bahia. Em viagem de carro com a família, Nilo, representante comercial em Ubá, encosta o carro para trocar o pneu que acaba de furar e engata uma conversa com Cabeludo, o borracheiro, natural de Rodeiro, mas que vive há mais de 30 anos no lugar. Trabalho não falta, "graças a Deus", diz o borracheiro, ou aos sucessivos governos que ano após ano contratam uma empreiteira para fazer remendos na estrada, recebem pelo serviço e devolvem uma parte para os políticos. "Na primeira chuva, volta tudo à estaca zero. Por 
conta disso tenho movimento dia e noite, sábado e domingo e feriado" (Idem, p. 62), prossegue.

Ele deixara há tanto tempo a sua terra natal que o nome da cidade, tão pouco conhecida, havia se tornado uma palavra "oca", "raro em raro pronunciada, um quadro esmaecido evocando uma cena além do tempo, fora do espaço" (Idem, p. 64). Pela primeira vez em mais de 30 anos, compartilhava com alguém a existência de Rodeiro. A cidade se erguia à sua frente: a igreja, o coreto, o jardim, os saguis saltando das árvores, as charretes, o cheiro de mijo e bosta de cavalo, a poeira, o canto melancólico dos carros de boi e as caras vermelhas da italianada. Num rompante, Cabeludo pede a Nilo que se um dia, por acaso, encontrasse alguém da família Finneto, dissesse que ele estava bem, e, quem sabe, um dia ainda voltaria. Mas, logo desiste da ideia estapafúrdia e pede: "por favor, não fala nada não...melhor assim...melhor pra todo mundo..." (2011, p. 67).

A distância física somada à distância afetiva cria uma sociedade de "náufragos", desviados de suas rotas pelo vento do progresso, na qual a ideia de pertencimento a uma coletividade e a transformação da realidade social são descartadas. O desejo de pertencimento é suplantado pelo desejo de consumo de bens concretos ou simbólicos.

Se Inferno provisório tinha começado com o episódio "Uma fábula", que narra a vida dos Michelletos na zona rural de Rodeiro (MG), a pentalogia se encerra com "Outra fábula", que retoma a história de Luiz Augusto - o primo 'caipira', de "Era uma vez" (O livro das impossibilidades, 2008) - como forma de reforçar uma estrutura circular em constante des(construção), em que nada de verdadeiramente transformador acontece. Numa e noutra fábula, convivem desarmonicamente a roça e a periferia decadente.

A tradicional corrida de São Silvestre, que acontece todo dia 31 de dezembro, há mais de 80 anos em São Paulo, serve de moldura para o episódio final. O ano é 2002 e a imagem de milhares de corredores anônimos, de camisetas numeradas, sob um calor de mais de 30 graus, aguardando impacientes a largada da prova que percorre as ruas da cidade, remete inexoravelmente à imagem da turba de indivíduos massacrados pelo cotidiano na metrópole representados em Eles eram muitos cavalos (2001). 
Como tantos personagens ruffatianos, vinte anos antes, de supetão, Luiz Augusto anunciara aos pais a sua partida para São Paulo, sabendo que se demorasse muito "talvez permanecesse para sempre atolado naquela cidade, naquele bairro, naquela morada, naquele pedaço estagnado do tempo" (2011, p. 76). De um lado, o pai, Seu Raul, acreditava que ficar em Cataguases era sinônimo de "comer algodão" e virar capacho dos Pratas. Para ele, em São Paulo, "quem tem força de vontade, vence". Pressagiava ainda que na metrópole, "um pote de moedas de ouro aguardava os destemidos" (Idem, p. 79) e que viver era "transpor a morraria". "É da roça para Cataguases e de Cataguases para São Paulo, São Paulo sim é um mundo, repetia” (2011, p. 90). Já a mãe Jânua, em sua velhice antecipada por ter passado a vida toda debruçada num fogão - "labutando manhã a noite, escrava dos seus ausentes fins de semana, feriados", alijada de festas e alegrias comezinhas (Idem, pp. 76) - entendia São Paulo como uma cidade hostil. Sabia de tantas mães que esgotaram os nervos em noites mal dormidas, outras de cabelos brancos "à espera de cartas nem sequer postadas" e outras que "morreram de desgosto por adivinhar o filho desencaminhado pela cidade grande, quantos e quantos para todo o sempre perdidos!” (Idem, p. 80).

O desejo de ter um carro zero-quilômetro, comprar casa, mobília e eletrodomésticos para os pais, virar doutor e impressionar os desacorçoados que se afundam nos obscuros e imundos botequins de sua cidade, logo é confrontado pelo frenético ir e vir de pessoas apressadas, de vendedores ambulantes e do tumulto de buzinas e automóveis neurastênicos com seus canos de descarga asfixiando a tarde. A vontade imediata é comprar uma passagem de volta.

No início fazia falta a taioba com angu, o jiló frito, o arroz doce, as manhãs recendendo a alho, a algazarra vespertina dos pardais, e até mesmo o cheiro enjoativo dos salgadinhos que a mãe fazia. Poucos meses depois, a casa da infância já se tornara estrangeira. Nunca antes tão pequena, onde viviam confinados, sonhando mundos melhores, diferentes, impossíveis. A decisão acaba sendo sempre o rompimento em definitivo com o passado, distanciando-se de tudo que lembrasse ainda que vagamente as suas origens. 
Não visitou o tio Juca em São Bernardo do Campo, nem a madrinha Alzira na Saúde. Recusou-se a percorrer os saguões do Museu do Ipiranga porque diziam que certa rua do bairro, a Silva Bueno, estava infestada de conterrâneos. Excomungou Diadema, porque lá, sabia, empregavam-se fresadores, torneiros e ajustadores mecânicos diplomados pelo Senai da sua cidade (Idem, p. 81)

Todos os dias dos seus últimos vinte anos dedicara a apagar os vestígios de sua passagem por Cataguases que desde a sua primeira ida a São Paulo, afunda lenta e inexoravelmente numa terrível agonia (Idem, p. 99). As voltas ficam cada vez mais espaçadas: a morte de um parente aqui, um casamento acolá. Luiz Augusto, assim como Mirim, Nelly, Vanim, Gilmar, Gesualdo, Jacinto, Aílton, deu as costas para o seu povo, "cartas esparsas, raros telefonemas, breves notícias" (Idem, p. 92). Mortos os pais, a casa da família é uma herança maldita, caindo aos pedaços. Enquanto isso, na São Paulo caótica

\begin{abstract}
vozes apregoam pedem protestam bradam solicitam impõem pregam abordam seduzem oferecem exigem incentivam mendigam sussurram incitam reprimem bramem vaiam clamam reclamam proclamam buzinas buzinas buzinas, roncam motocicletas roncam carros roncam ônibus roncam caminhões roncam helicópteros roncam não há vagas volte outra hora sabe dirigir? Tem veículo próprio? Experiência no ramo? Resmungos desprezos desdéns (Idem, p. 101).
\end{abstract}

Passados vinte anos, separado e com dois filhos, Luiz Augusto leva uma vida simplória na capital paulista, trabalhando como jornalista de revistas de sindicato e de circulação dirigida, onde ganha vencimentos ordinários. Náufrago de sua própria história, imerso entre "os milhares de calções e camisetas numeradas, sob um calor de mais de trinta graus, aguardando o sinal para o início da largada da Corrida de São Silvestre” (2011, p. 106), Luís Augusto esconde-se na multidão de mais de 20 mil pessoas, vindas de diversas partes do Brasil e do mundo. Anônimos que, na impossibilidade de escreverem seus nomes, de lembrar suas origens e pelagens, tais quais as personagens do romance que projetou Ruffato, vestem camisas numeradas e correm em desatino na tentativa de "ludibriar a morte". Como escreve Giovanna Dealtry em ensaio sobre o romance de 2001, mas que se encaixa na retomada do tema em Domingos sem Deus, o desfecho da corrida representa mais que um final em aberto: é "um final em abandono" (2007, p. 170). 


\section{Sob o signo da ruína}

"Ruínas, forma e conteúdo, apenas ruínas"

(RUFFATO, 2008, “Até aqui tudo bem”, p. 322).

As histórias de vida descritas em Inferno provisório, assim como a estratégia narrativa utilizada por Luiz Ruffato no ciclo-épico para reforçar a precariedade das vidas de suas personagens "invisíveis", ajudam a compor uma imagem arruinada da nação. $\mathrm{O}$ autor opera uma dupla subversão, para a qual chama a atenção Marcos Vinícius Ferreira de Oliveira no ensaio Tecido em Ruínas: "no plano estético, desmonta a forma usual de romance e no plano ideológico se apropria do conceito benjaminiano de ruína" (2013, p. 35), conforme já havia apontado Giovanna Dealtry ${ }^{21}$. A deterioração das relações sociais, diagnostica o próprio Ruffato, "emerge na precariedade formal do livro, que avança sem avançar, que tartamudeia em espasmos, numa espiral de solidão, abandono e denegação. Ruínas, forma e conteúdo, apenas ruínas...” (“Até aqui tudo bem", 2008, p. 322).

Ao captar fragmentos de um todo malogrado, Inferno provisório inquire sobre os meandros de um projeto de modernização excludente, cujos resultados ajudaram a perpetuar as profundas desigualdades nacionais. Assim, o autor resgata a história recente de um país que "adentrou às labirínticas instâncias da pós-modernidade sem ter passado, com alguma solidez, pelos necessários estágios da modernidade", ou seja, sem ter alicerçado sua autonomia no desenvolvimento dos campos da educação, cultura, saúde e cidadania (OLIVEIRA, 2013, p. 15).

A história nacional combina elementos de um crescimento econômico em níveis altamente acelerados - no campo das tecnologias de comunicação, produção energética, indústria automobilística, entre outros - aliado ao mais profundo atraso social, de modo que grande parte da população não é atingida pelas benesses de tal progresso. Em vez de uma modernização inacabada, vivenciamos uma

21 “Cidade em ruínas: a história a contrapelo em Inferno provisório, de Luiz Ruffato" (2009). 
modernização finalizada, porém, como observa Oliveira, com "danos irreversíveis para a população que não foi contemplada com o espetáculo vernacular da modernização e para quem a modernidade é um discurso tão distante quanto inacessível" (Idem, p. 73).

Este desgaste social aparece sobretudo em relatos em que aparentemente nada acontece, a não ser o estado de degradação e abandono de lugares e pessoas, nos quais a simples descrição de uma imagem arruinada, revela mais do que o enredo final ou a biografia dos protagonistas. A ruína está, pois, nos indivíduos, nas frases, nas famílias, nos capítulos, nos bairros, nos cinco volumes que compõem a saga.

A devastação se manifesta, por exemplo, no corpo fraco de D. Paula, lavadeira, que em "Sulfato de Morfina" é atacada por um câncer. $\mathrm{Na}$ "falta de carnes, amparava os ossos pelas paredes da casa minúscula", "a dentadura superior expulsa da boca murcha perdeu-se em meio a capoeira do quarador, a urina quente escorreu entre as pernas, e a mulher amparou-se desequilibrada". Com cabelos precocemente embranquecidos, zonza, com ânsia de vômito, pergunta-se: "melhor morrer, estou morrendo?" (RUFFATO, Mamma son tanto Felice, 2005, p. 29 - 30).

Se outrora lavava roupas finas do povo da Rua do Comércio, da Praça da Estação, da Avenida, em Cataguases, de "médicos, adevogados, juízes, sim, juízes!", com suas "calças ricas, tropical, linho, gabardine, tricoline, tergal” e ainda os "vestidos tristes das mulheres da Ilha, paetês, vidrilhos, lese...E a chita, o brim dos da vala-comum", da noite para o dia, somem-lhe "as forças para lavar uma cueca, uma calcinha, um par de meias" (Idem, p. 31).

Entregue à doença, descorada, sem fôlego, arrasta os chinelos de solas gastas, numa atmosfera abafada, de mofo e podridão, enquanto o "preguiçoso tique-taque empurra a tarde contra a noite contra a madrugada", no "pinga-pingar vagaroso das horas" (Idem, p. 32). Sem serventia à sociedade, longe dos filhos que partiram para os grandes centros em busca de trabalho, vivia com receio de passar mal e não ter a quem recorrer, até murchar os dias "sem comer sem falar sem desejar outra panaceia que não o fim" (Idem, p. 41). 
Também no episódio "O segredo", que narra a história de um metódico e obsessivo professor, paira a fantasmagoria da solidão e da ruína. Apesar de sua realidade contrastar com a da massa de trabalhadores cuja rotina é trabalhar para sobreviver, vê a sua vida desmoronar após saber do adoecimento de sua empregada doméstica, D. Conceição, moradora do Beco do Zé Pinto, espécie de cortiço de casas onde vivem os marginalizados da cidade de Cataguases. Passados alguns dias sem notícias da funcionária, ele vai até a sua residência, onde descobre que ela morrera e onde é conduzido pelo senhorio ao indigno cômodo em que vivia a empregada.

\begin{abstract}
Uma cortina de brim azul tampava um buraco escavado na parede do porão. Zé Pinto desvencilhou-se do pano, entrou, estendeu os braços para todas as direções e disse: 'Era aqui que ela morava'. E levantando os olhos para o teto, emendou: 'Que Deus lhe dê um bom lugar'. Os olhos do Professor custaram a acostumar-se com a penumbra. Quando a vista se firmou, divisou um cômodo minúsculo, um beliche de um lado, um urinol por debaixo, uma mesinha perneta, um fogareiro a álcool, uma lata de gordura de coco vazia, um guarda roupa caindo aos pedaços e uma vassoura de piaçaba. Mais nada (Idem, p. 164).
\end{abstract}

Em contraste com a miséria de D. Conceição, o professor tinha uma vida decente. Além das três refeições diárias, da roupa passada, da casa limpa - o que por si só já o distinguia da média das personagens da saga, que viviam à margem da cidadania - ele é a primeira personagem que destoa da ignorância que circunda os habitantes da pequena cidade mineira. Leitor dos clássicos gregos e romanos, poeta e professor, a personagem passa o conto a especular sobre a música que encomendaria para o dia de seu enterro: Bach ou Beethoven? Apesar de tanta erudição, ele sabe que todo esse conhecimento adquirido só o torna mais inadequado e solitário. Menino criado na Serra da Onça, o culto protagonista do episódio que encerra Mamma son tanto Felice, relembra a vida boba e insossa da infância, quando ainda não conhecia a infelicidade: “a felicidade é a ignorância...O homem que não conhece, esse o homem feliz. O conhecimento é a cobra que criamos para nos picar...é o muro que nos aparta para sempre da felicidade...”, filosofa. "Éramos tão inocentes...tão ignorantes...tão...felizes...Ah!, os tempos felizes da minha miséria...”(RUFFATO, Mamma son tanto Felice, 2005, p. 135-136). Em outros tempos, o professor, ainda menino, deixara a sua cidade natal para seguir nos estudos, mas, para ela retorna na ocasião da morte de 
sua mãe. Revê amigos e parentes e chega a desejar viver por lá, mas, “...Já não pertencia àquele universo" (Idem, p. 161).

quanto mais conhecia, mais queria conhecer. E, quanto mais conhecia, mais infeliz me tornava...sou um homem só...Um homem só no mundo...Perdi minhas antigas referências, o sítio, meus pais, meus irmãos, a paisagem da minha infância...E não acrescentei nada a isso...O que resta do meu passado? Ruínas...Apenas ruínas...Não os procurei mais (Idem, p. 162).

Diante de sua culpa - desencadeada pela morte de D. Conceição, e pela assistência prestada à filha dela, Silvana -, passa a ter delírios e alucinações de que estaria sendo julgado como Cristo - por toda a sociedade cataguense, como um "traidor da família, da igreja Católica, das leis elementares do país, explorador da ingenuidade e da confiança alheios, perturbador da ordem pública” (Idem, p. 154), conforme gritava a turba assanhada em "O segredo".

A narrativa não deixa claro se houve algum assédio real à menina ou se se tratava de um desatino ou alucinação, de modo que o desmoronar da reputação e do lugar ocupado pelo professor na sociedade chamam mais a atenção do que o próprio enredo. Ele se desliga do quadro de professores e do jornal para o qual colaborava, por sentir que sua vida estava "de cabeça para baixo" (RUFFATO, Mamma son tanto Felice, 2005, p. 146) ou seu mundo estava se despedaçando (Idem, p. 147). “- O senhor sabe, doutor Divaldo...a minha vida...Só consigo ver ruínas à minha volta...Ruínas...Apenas ruínas...” (Idem, p. 147).

De volta à casa da infância, onde outrora existia uma casinha de sapé que botava fumaça pela chaminé, percebe que dela restaram apenas escombros. "Ninguém mais quer ficar na roça, a moda agora é a cidade" (Idem, p. 139), comenta. "Pendurada no despenhadeiro, paredes arriadas, destelhada, a cruz envolvida numa massa disforme que foi um dia papel-crepom colorido agora agarrada à porta desnecessária" (Ibidem). Onde antes havia meninos correndo atrás da charrete e afetuosos comprimentos, "Tarde! Tarde!, E a comadre? Vai benzinho, como Deus é servido! Quer entrar não?, tomar um cafezinho?” (Idem, p.140), agora, 
lonjuras, tudo vazio, cresce a capoeira, o mato engole tudo, sobe pelas paredes caídas, arruinadas, sufocam as árvores, um carro-de-boi sem uma roda apodrece debaixo de uma cumeeira do que um dia foi um rancho de curar fumo, vozes, o vento abóia um lamento (Idem, p. 140)

$\mathrm{Na}$ casa, nada de luz, nada de fumaça, "a lua cunhara uma brecha entre as gordas nuvens e clareava o que restara, ruínas: espalhados pelo derredor cacos de telhas e pedaços de tijolos, vigamentos, um caldeirão amassado, um tanque de cimento....E mato, mato, mato" (Idem, p. 141). Acuado por seus pensamentos e delírios, a personagem pensa em fugir de sua história, pegar um ônibus e parar numa cidadezinha qualquer: "Um desmemoriado...Isso! Está cheio de gente assim por aí, não está? Um homem sem memória. Sem documento. Sem passado! Começar tudo de novo..." (Idem, p. 158), deseja destruir o passado e construir uma nova existência, sobre novos alicerces.

Acompanham o texto expressões que remetem a uma tempestade avassaladora e ajudam a compor o quadro dramático: uma música que "irrompe soberana"; um "raio que assusta a noite" e um trovão que explode, a "algazarra da tempestade" (Idem, p. 125), que remete a ideia de ruína, desenvolvida por Walter Benjamin, nas teses "Sobre o conceito de história", a respeito do quadro Angelus Novus, de Paul Klee. O quadro representa um anjo que parece querer se afastar de qualquer coisa que olha fixamente. Com olhos escancarados, a boca dilatada e as asas abertas, o "anjo da história" volta os olhos para o passado e, "onde nós vemos uma cadeia de acontecimentos, ele vê uma catástrofe única, que acumula incansavelmente ruína sobre ruína”. Ele gostaria de deter-se,

mas uma tempestade sopra do paraíso e prende-se em suas asas com tanta força que ele não pode mais fechá-las. Essa tempestade o impele irremediavelmente para o futuro, ao qual ele vira as costas, enquanto o amontoado de ruínas cresce até o céu. Essa tempestade é o que chamamos progresso (1994, p. 226).

Também Vicente Cambota, personagem do conto homônimo, publicado em Vista Parcial da noite (2006), terceiro volume do Inferno provisório, tem a sua trajetória marcada pela degradação e pontuada pela violência da tempestade. 
Nascido sem o nome do pai na certidão e criado por uma mãe doida, com quem vivia "de favor" num buraco úmido e escuro escavado no porão do Beco do Zé Pinto, cujo cheiro mesclava "urina mofo podridão", cresceu vestindo roupas sempre menores que as partes, ganhas em campanhas do agasalho, sujeito a todo o tipo de doença "caxumba e sarampo, bertoeja e catapora, caganeira e sapinho, piolho e sarna, cobreiro e coqueluche, crupe e frieira, furunco e pereba, micose e terçol, lombriga e barriga vazia" (RUFFATO, Vista parcial da noite, 2006, p.119).

Vivia ao deus-dará. Não precisava tomar banho, escovar os dentes ou ir à escola... Até que tudo imergiu na escuridão. A mãe enlouquecera e a polícia despejou-a na Casa de Saúde. O menino amuou, "reclamando a mãe, bezerramente renegando a fatalidade" (Idem, p. 121). Penalizado, Zé Pinto, acomodou-o numa chacrinha no bairro do Paraíso, na periferia da cidade, para que tomasse conta da horta e das galinhas e para espantar as formigas, cavalos e ociosos. Mas, à medida que espichava, "convertia-se noutro. O menino seucriado, macambúzio sim, mas cordato, florescia em amigo da jogatina e cachaça" (Idem, p. 124).

Num janeiro torrencial, "cujas águas arrebentaram os barrancos”, quando já não o respeitavam crianças nem vira-latas, apareceu-lhe uma mancha vermelha que se transformou em chagas doloridas. "Em busca do de-comer" invadia quintais e esmolava trocados para beber cachaça. Foi escorraçado da chacrinha onde vivia pelo próprio Zé Pinto, conduzindo sem se dar conta de que sua vida descia ladeira abaixo, feito rolimã.

"Desmodelo para moleques arruaceiros", largado no pasto, "espojado numa poça de sangue podre" é internado, como a mãe, na Casa de Saúde, deixando médicos e enfermeiras nauseados pelo aspecto de suas escaras. Voltando a si, foge do hospital e mais uma vez imagens de tempestade arrebatam com violência os moradores de Cataguases. "Relâmpagos estralejando trovões"; os primeiros pingos alcançaram-no na Vila Teresa. Estoura um raio desligando a luz da rua, e 
a treva se apossou do mundo....a chuva apertou, látegos de água fria chicoteavam seu corpo, tonto, os remédios, relâmpagos latejam trovões...a enxurrada arrasta o barro que desce das encostas desaterradas do Beira-Rio, atola os pés, nada enxerga, escorrega, o chão desmorona, pensa gritar, uma cratera engole-o, metade dentro do bueiro, metade fora (2006, p.127)

A violência da tempestade contrasta com a fragilidade e o desamparo das personagens. Corpos doentes, embriagados, "caindo aos pedaços" são arrastados com fúria pela enxurrada. O que vemos são personagens afundando, afundando, sem nem sequer pedir socorro, pois que a esperança é abafada por um presente trágico, hostil e impositivo. O resultado é uma catástrofe única que acumula ruína sobre ruína.

A espiral de degradação é também o mote do capítulo "Sorte teve a Sandra", publicado em Domingos sem Deus (2011). Moradora do Ana Carrara, periferia de Cataguases, Sandra catou as roupas, enfiou-as numa bolsa de napa e escapuliu para o Rio de Janeiro, para tentar a vida como empregada doméstica num minúsculo quarto escuro e embolorado, "cama e guarda roupa imprensados" (RUFFATO, 2011, p. 46).

Por cinco meses mal frequentou a rua, encarcerada, vivendo para "arrumar, limpar, cozinhar, lavar, passar" (Ibidem) até conquistar os sábados e domingos para ir em busca de onde houvesse pagode. Num "janeiro verde-branco" (Idem, 47), na quadra da Imperatriz conheceu Fafá. Quando descobriu-se com a barriga saliente, perdeu de vista o mulato dengoso e aportou "mão na frente mão atrás" (ibidem) de volta à casa da mãe em Ana Carrara, Cataguases.

Crescido o menino que nasceu, Sandra volta para o Rio de Janeiro, trabalha em biscates e como caixa de supermercado até se firmar como dançarina numa boate chique em Ipanema. Os olhos baldios de Fred, um tipo "artista", cantor de bar, fisgam Sandra. Pouco depois descobre-se prenha do namorado com quem decide ter o neném. Até que, num alvorecer, descobre que o quarto e sala em que viviam fora "subtraído dos eletrodomésticos, das roupas, dos poucos ouros, das muitas bijuterias" e as economias do banco saqueadas pelo namorado (RUFFATO, 2011, p. 50). Resignada, volta mais uma vez a Cataguases, onde se descobre com aids, ela e o neném "ainda mamão" (Idem, p. 51). 
A falta de dinheiro e assistência, as doenças, as mortes e as migrações compõem um cenário baldio, infrutífero e sem possibilidade de cultivo, seja na vida rural de Mamma son tanto Felice (2005), ambientada nos anos 1950, seja na cidade "purgatório da beleza e do caos", descrita em Domingos sem Deus (2011), que se passa já próximo à virada do milênio. Almas como a de D. Paula, do professor e de Sandra, dentre tantas outras que povoam as 38 histórias de Inferno provisório resistem como podem para não chafurdar na lama como Vicente Cambota.

\subsection{Fora da ordem e do progresso}

En ciertos escritores este concepto de la historia, ya no como progreso a um mundo mejor sino como um callejón sin salida impacta en la propia narrativa (CARPENTIER, In: Figueiredo, 1994, p. 27).

O dístico positivista da bandeira, "Ordem e progresso", foi ideia de Raimundo Teixeira Mendes, matemático e filósofo adepto das ideias de Augusto Comte - o amor por princípio, a ordem por base, o progresso por fim -, que preconizavam o fim da escravidão, a proclamação da República e a separação Estado / Igreja, trio de objetivos que se acabara por atingir no Brasil. E que implicavam a implementação de reformas sociais que permitissem a incorporação do proletário e do antigo braço cativo à sociedade, ou seja, a inclusão social. A bandeira, ou melhor, a República prometia progresso, legislação trabalhista, criaria condições sociais básicas (respeito à cidadania, salários dignos) e o melhoramento do país (em termos materiais, intelectuais e sobretudo morais).

Ao escovar a história a contrapelo, Luiz Ruffato, no entanto, faz emergir a barbárie forjada e escondida sob o lema da ordem e do progresso. Se a história oficial vai enaltecer avanços econômicos e sociais ancorados na História evolutiva, que proclama a República, instaura o Estado Novo, desenvolve o país, como nos anos JK, ou no milagre econômico da Ditatura militar, o autor mineiro buscará representar o que ficou de fora dos livros oficiais de história. Ele irá trazer à tona uma história descompassada e inconclusa, da qual vemos emergirem 
histórias que são e não são parte da história do Brasil. Histórias fora da ordem e do progresso.

Em Inferno provisório não há a crença de que a história caminhe certo por linhas tortas, obedecendo a uma lógica interna que conduz ao progresso e à justiça social. Ao contrário, as forças da história destroem o futuro, tornando inviável pensar nossa trajetória como uma linha evolutiva, já que os projetos são constantemente adiados.

Para narrar a sua versão da história dos vencidos, Ruffato abre mão da temporalidade horizontal se propondo repensar o passado em termos nãoevolutivos. Os conceitos teleológicos de causalidade, linearidade e continuidade progressiva, tão comuns ao realismo clássico, são dispensados. A narrativa não supõe a sequencialidade contínua, fundada sobre a ideia de tempo como seta e sobre a ideia da ação progressiva dos homens em direção ao futuro (OLINTO, 2000, p. 115).

Composta por um conjunto de micro contos sobre famílias de trabalhadores de baixa renda que vivem no entorno de Cataguases, cidade natal do autor, a série Inferno provisório, abrange "várias unidades compreensíveis se lidas separadamente, mas funcionalmente interligadas, pois que se desdobram e se explicam e se espraiam umas nas outras, numa ainda precária transposição da hipertextualidade" (RUFFATO, 2008. "Até aqui tudo bem”, p. 323).

Por não ser a narrativa evolutiva ou sequencial, o leitor da saga pode optar por ler os volumes ou as histórias fora da ordem de publicação ou até mesmo optar por ler um volume em detrimento do outro sem que o enredo fique comprometido, pois as histórias assumem uma circularidade, contaminando umas às outras. $\mathrm{O}$ conjunto vai ganhando ao longo da leitura o status de romance. No entanto, é bem longe dos "parâmetros preestabelecidos que apreendemos a definição de romance para Luiz Ruffato", conforme escreve Cecília Almeida Salles na contracapa do primeiro volume.

Como cada relato remete a outro, funcionando tal qual uma "ciranda de personagens", os volumes têm função suplementar um em relação ao outro, de modo que de um capítulo a outro ou de um volume a outro pode-se penetrar 
melhor na complexidade de cada personagem, sem que a inteligibilidade do todo seja comprometida. "Puxasse o cordão surgiriam atadas as histórias", explica o narrador, no episódio "Sulfato de Morfina", do primeiro volume (RUFFATO, 2005, v. 1, p.37).

Ao se utilizar de planos e episódios simultâneos e fragmentados, o macro romance chama a atenção para a farsa da evolução da história dos vencedores. Nada de verdadeiramente transformador pode ocorrer, nenhuma mudança substancial, só de superfície, dentro de uma estrutura imóvel. Aos marginalizados resta a ruína e a repetição. Essa técnica de narrar aponta para o processo deformado e frustrado de nossa história.

"Uma fábula", narrativa que abre o volume 1, mostra de um lado o apodrecimento mesquinho da matriarca "Micheletta velha", que gastava seus dias trancada num quarto insalubre, e de outro o sonho constantemente adiado de Andrezim, 14 anos, de mudar de vida. Depois da morte dos pais, desejava deixar Cataguases rumo a Ubá: "diz-que cidade grande, de amplas modernidades, espiava o ônibus resfolegante na praça, Cataguases-Ubá...iria ainda, deixa estar, arrumava emprego numa fábrica de móveis, ganhava dinheiro, punha um implante de dente de ouro na boca" (V. 1; p. 24). Perseguia a ideia "decidindo, terça-feira, ir embora na segunda" e estudava como se desfazer de seus pertences - "A enxada negócio, E a bicicleta?” e não encontrando solução “catapultava a viagem para uma data mais adiante" (v.1; p, 24).

A interrupção abrupta das histórias, o adiamento dos sonhos das personagens aparecem de forma intermitente em diversos episódios, dos cinco volumes que compõem o conjunto. Os projetos individuais das personagens, à semelhança dos projetos coletivos da nação, são continuamente abortados: Gilmar, personagem de "A demolição" ( $O$ mundo inimigo, 2005), finalmente atuando como jogador do Palmeiras, no estádio do XV de Novembro de Piracicaba lotado, zagueiros, já dentro dos limites da grande área, Agora!, e rolou em contrações pela grama rala, a perna direita travada pela chuteira do beque adversário, o anil do domingo estilhaçado em seus olhos (RUFFATO, 2005, O mundo inimigo, p. 32). 
Anos depois ouvia ainda o "Pênalti!", “arruinado, mirando o mofo no teto do vestiário de algum estádio do interior, cheiro de alcânfor, pulando enjeitado de cidade em cidade, desabando de divisão em divisão" (Idem, p. 32) até desistir da carreira e tentar a vida como dono de botequim na garagem de um sobrado em São Paulo. A carreira de jogador de futebol acabara numa "tarde mergulhada no nunca-jamais" (Idem, p. 32).

O episódio "A solução" publicado anteriormente em (os sobreviventes), e agora em $O$ mundo inimigo, volume 2 de Inferno provisório, retoma o tema de que a única solução para a mesmice e falta de perspectiva da cidade de Cataguases, esquecida no tempo, é abandoná-la.

Tomada por sentimentos de aflição e raiva na espera da colega que a renderia na fábrica de tecidos, Hélia rói a unha, envolta pelo ronco dos teares, e não consegue controlar o seu ódio: “A zanga fumegava nos espasmos de suas pálpebras" (Idem, p. 63). Arranca com violência o lenço da cabeça, os olhos envenenados e a voz esgarçada a levam ao desespero. Bate o ponto e "droga! lá vem aquela vontade de chorar, manteiga-derretida!” (Ibidem). Ao perder o ônibus, sonha com o Clube de Remo, frequentado pelos bacanas da cidade, ao qual jamais teria acesso. "Ai meu deus quem me dera! Mas quem sou eu?”, pergunta Hélia (RUFFATO, 2005, O mundo inimigo, p. 64), uma espécie de gata borralheira, para quem a solução seria se casar com um homem rico.

alguém que me tire...que me leve embora daqui...desse buraco...Ah, isso eu também quero, disse a Márcia. Quem não quer?, disse a Toninha, concluindo, O difícil é conseguir. Pois eu vou arrumar, vocês vão ver! [...] vou conquistar um homem rico, bem rico, disse, elevando os olhos para os picumãs enrodilhados nas telhas enegrecidas. (Idem, p. 65)

É sábado à tarde no Beco do Zé Pinto e as amigas se divertem contando intimidades adolescentes. Os sons do beco entram pelo quarto: meninos jogando bola de gude, meninas brincando de queimado, uma mãe atrás do filho levado, vizinhas de papo tirando a roupa do varal. 
O arrastado dos dias, entre o Bar Elite, a Praça Rui Barbosa, a fábrica, a Ponte Nova, pontuam o constante desejo de Hélia mudar seu destino. Primeiro apagar o passado, uma vez que tinha vergonha de sua trajetória. A mãe, D. Zulmira, lavadeira e semianalfabeta e o pai, Seu Marlindo, não passava "de um...biscateiro...Deus me livre e guarde!” (RUFFATO, O mundo inimigo, 2005, p. 67). O namorado esforçava-se para se entrosar com os sogros: "vou arrumar umas lavagens de roupa para a senhora, deixa estar!" dizia para D. Zulmira. Mas Hélia não gostava daquela camaradagem. Queria esquecer que tinha família: "ah, se pudesse enterrar o passado!", pensar, "minha mãe morreu no parto, coitada, e meu pai quando eu tinha uns seis anos...Fui criada por uma parenta distante, muito rica...' Sim, era vergonha o que sentia, vergonha...” (Idem, p. 67).

Os dias de Hélia se arrastam na mesma maçante rotina. Almoçar sem vontade, tomar um café requentado e voltar para o trabalho: "ouvir o apito, bater o cartão de ponto, se enterrar novamente no ar úmido da tecelagem, todos os dias, todos os meses, todos os anos, até o fim dos tempos...não, não queria voltar para casa” (Idem, p. 70-71). O desânimo consome seus dias. "Às vezes acho que nunca vou conseguir...É tudo tão difícil!". - “Conseguir o que Hélia?, perguntou a Márcia". "Sair...sair desse beco...dessa vida..." (Idem, p. 69).

O beco do Zé Pinto surge como uma metáfora para a falta de saída para a cidade, para o país ou as nações periféricas diante de seus eternos impasses. $\mathrm{Na}$ periferia do mundo, Hélia vivencia uma história de processos deformados e frustrados, uma história marcada por fracassos, recuos e abortos de projetos. Assim, a ideia de história hegeliana, marcada pelo progresso, é substituída pela ideia de beco sem saída - callejón sin salida - proposta pelo autor cubano Alejo Carpentier em A literatura do maravilhoso (In: FIGUEIREDO, 1994, p. 27).

$\mathrm{Na}$ falta de perspectivas reais, de uma vida mais digna e promissora, a moça concebe um Deus ex machina nesse casamento fantasia, nesse príncipe imaginário que a tiraria dessa vida: "O difícil é conseguir" (RUFFATO, 2005, O mundo inimigo, 2005, p. 65). Em casa, trancada em seu quarto, cansada do que a realidade lhe apresenta, Hélia deixa-se levar pela imaginação. Veste um tubinho vermelho, calça uma sandália preta, põe um brinco de pressão de florzinhas vermelhas, passa batom, pó-de-arroz, espalha sândalo pelo corpo. Apaga a luz. 
Hélia está numa festa de debutantes no Clube Social. Caminha devagar, polinizando as mesas com sua graça e simpatia, deixando para traz olhares prenhes de inveja e de cobiça. Sussurros. Quem é a moça. Nossa, como é linda! Flutua dos pés à cabeça coberta de admiração. Um rapaz alto, louro, olhos azuis levanta-se, puxa uma cadeira, convida-a para sentar-se, Obrigada. Meu deus, quem é você? De que reino você fugiu? (Idem, p. 71)

Subitamente uma briga entre Zé Bundinha e D. Fátima, vizinhos no Beco Zé do Pinto, soa como as doze badaladas da meia-noite e o encanto da Cinderela mineira se acaba: "Vou te matar desgraçada!, e gritos, gritos histéricos, e barulho de vasilhas desabando no chão"... "Para, Zé Bundinha, para! Chama a polícia! Para, Zé Bundinha! Chama a polícia!, Ele vai matar a Dona Fátima!”. Quebra-se o delírio de Hélia que desliza o corpo sobre o sofá de vinil vermelho. Quieta, encolhe as pernas, abraça-as e encaixa o queixo no vão dos joelhos. Desiludida, acende a luz e desmonta o figurino; "Veste a camisola branca, deita-se de bruços, o travesseiro cobrindo a cabeça. E então um tremor abala seu peito, uma enchente, há muito contida, espalha-se selvagem, explodindo numa convulsão em seu corpo macerado" (Idem, p. 72). No dia seguinte, o sol quente torrando a sua cabeça enterra as suas esperanças: "não, nunca vou sair desse inferno" (Idem, p. 72).

O modelo descritivo de história privilegiado por Ruffato favorece a emergência de uma realidade presente na forma de montagem, ou seja, uma realidade que dispensa nexos, sem relação explícita, sem explicação plausível ou obrigatória. Tanto assim que, o episódio seguinte, "A mancha" não é um desdobramento deste. $\mathrm{O}$ que dá unidade à sequência de histórias é a cidade de Cataguases, o Beco, a falta de perspectiva das personagens, o aborto de projetos, $\mathrm{o}$ signo da ruína.

Os três episódios que se seguem, "A mancha", "Jorge Pelado" e "Ciranda" formam um conjunto de histórias, mas que dispensam a ideia de continuidade ou desdobramento. São na verdade fragmentos da história de D. Bibica e seus três filhos, Marquinhos, Jorge Pelado e Zunga, com quem vive amontoada num cômodo do Beco do Zé Pinto.

"A mancha" expõe a humilhação sofrida por Bibica, ex-prostituta e atual lavadeira, que se deixa cair na lábia do comerciante português, Seu Antônio “boa bisca!" (RUFFATO, 2005, O mundo inimigo, p. 77), que na hora de lhe 
propor "safadezas" a enche de presentes: "pó de arroz, perfume, água de rosas, batom, espelho, esmalte, correntinha banhada a ouro" (Idem, p. 79), mas quando a descobre grávida é só insultos.

Arrasta-a pelo braço até o banheiro fedendo a creolina e grita: "fícaste maluca? Queres destruir meu casamento?, desonrar meu nome na praça? [...] Enlouqueceste D. Bibica? Com certeza enlouqueceste!” (Idem, p. 81). E a escorraça de seu comércio dizendo não ter nada com isso. Ao que, pálida, D. Bibica reage com inábeis escusas: “Não fiz por mal...desculpe...não sabia que o senhor ia ficar tão bravo, desculpe...' e escapuliu chorando" (Idem, p. 82).

A narrativa tem sequência na história de Marquinho, o fruto da relação do casal, ou "filho da enchente" como gozava o dono do Beco, Seu Zé Pinto. O menino de 10 anos tem seus sonhos interrompidos por um ônibus, quando "todo serelepe, orgulhoso da rabiola e do cortante do seu papagaio" (Idem, p. 75) é atropelado na frente da mercearia do pai biológico.

"A mancha" que dá título ao episódio remete tanto ao sangue deixado no asfalto pelo menino morto quanto ao passado profissional de Bibica, que sofria com a fama de perdida: "queria apagar aquela passagem de sua vida, uma gosma, uma lepra, uma mancha que não saia nem esfregando com todo o sabão do mundo" (Idem, p. 77).

Marquinho, como a nau dos versos de Jorge de Lima, que servem de epígrafe aos cinco volumes da saga, não chega a lugar algum, pois seu destino já fora traçado podre desde a origem. Assim é também a trajetória de Jorge, o filho do meio de Bibica, cuja história é narrada na seção "Jorge Pelado", que se subdivide em 2 partes: 'Agonia' e 'Lamentação'.

Jorginho é fruto de um paratifo que o irmão mais velho, o Zunga teve. Para conseguir o dinheiro dos remédios necessários para a cura do filho, Bibica "foi e voltou quatro vezes [ao bordel], cada uma com um homem diferente, tinha que fingir que estava gostando da função, mas a cabeça lá longe: Será que a febre baixou?" (Idem, p. 102).

A primeira parte, como o próprio título sugere, narra a aflição do rapaz imaginando-se pego a qualquer momento pela polícia: “Jorge Pelado acorda 
bombardeio no peito o trintaeoito mira trêmulo o breu um barulho sonho?" (Idem, p. 91). Após ter roubado uma bola e uma bicicleta na rua do Comércio para brincar com os amigos, o rapaz passa a ser perseguido e esculachado pela polícia. Bibica em sua ingenuidade e hospitalidade mineira avisa aos PMs: "Pode entrar é só não arreparar na bagunça...casa de pobre...aceita um cafezinho? Coei agorinha, agorinha" (Ibidem). Não é com a mesma simpatia, no entanto, que os soldados tratam Bibica, gerando um grande mal-estar na família. Diz Doutor Normando, bicheiro e patrão de Zunga

Só porque eles falaram umas verdades para a Bibica o menino virou homem? Que isso? Onde nós estamos? Porque um homem levar uns tapas no pé-da-orelha não é vergonha nenhuma, não é o fim do mundo...em vez de enfiar o rabo entre as pernas, ficar quieto no canto dele, não, o que que ele foi fazer? Comprou um punhal e fica por aí alardeando grandezas, que vai espetar esse, que vai sangrar aquele (Idem, p. 96).

Dr. Normando anuncia ainda que a única saída para o rapaz seria despachálo de Cataguases para o Rio: "lá o Jorginho vai ter chance de arrumar uma colocação, virar gente...E com juízo, até volta um dia para cá, de carro e tudo" (RUFFATO, 2005, O mundo inimigo, p. 96), avisa o bicheiro para a família, que resolve seguir seus conselhos.

Antes do roubo, Jorginho até cultivava o gosto de deixar um dia Cataguases. Ia todo domingo à Rodoviária, imaginando que "todo lorde, na primeira poltrona cumprimentaria os conterrâneos. Aquele ali não é o Jorge da Bibica? É sim... Como está mudado...É endinheirou...Roupa-de-ver-Deus" (Idem, p. 93). Não podia especular que as condições fossem tão impróprias: fugir das ameaças da polícia. O resultado dessa fuga inesperada é que "nem uma carta nunca escreveu. Também Bibica não sabia ler e ele mal e mal garranchava o alfabeto" (Ibidem).

Pobreza, analfabetismo, violência, rompimento dos laços familiares e a falta de perspectiva se acentuam na segunda parte da seção, Lamentação, quando Ruffato narra o sofrimento de Bibica por ter deixado o filho "escapulir para o Rio". "Lá longe, sozinho, convivendo com tudo quanto é ruindade" (RUFFATO, 2005, O mundo inimigo, p. 101). Não conhecia ninguém que tivesse voltado. No 
primeiro ano, ainda manteve a esperança de que ele fosse voltar, que abriria a porta todo fagueiro, "cheguei Bibica, põe a panela na trempe aí e faz um mingaude-fubá-com-couve pra mim", "mas depois desistiu como se ele tivesse morrido, sem enterro" (Idem, p. 105).

Anos depois, quase cega, "arrastando as varizes pelo assoalho dos corredores úmidos do Asilo São Vicente de Paula, já sem forças para nada" (Idem, p. 106), Bibica termina os seus dias louca, vendo o filho voando com um cavalo branco. "Deus não perdoa uma mãe que entrega de mão beijada um filho para uma cidade comedeira de gente que nem o Rio de Janeiro", resmunga.

O sétimo episódio, Ciranda, narra o dia a dia de Zunga, também filho de Bibica, alcoólatra, pedófilo, amante da jogatina e violento, que dia após dia segue a mesma e indisciplinada rotina. Bebe, bate na namorada, a prostituta Cidinha, dorme, vomita, rouba o dinheiro da mãe, vai ao cinema bolinar os meninos, joga a valer, bebe, bate na namorada....numa incansável ciranda em que nada de verdadeiramente transformador acontece.

Assim, a coletânea traz uma rede de referenciais transversais que, a exemplo dos hipertextos, facultam ao leitor, escolhas e caminhadas sem direção. As imagens do rizoma, de uma realidade nacional que corre sem ter começo e nem foz, a do curso que é constante é vário ${ }^{22}$, e a do beco sem saída são evocadas de maneira cíclica. A cada história, a cada volume, o autor apresenta mais do mesmo de maneira aleatória como bem ilustra o episódio "Estação das Águas", publicado em Vista parcial da noite (2006), terceiro volume de Inferno provisório.

O trecho que introduz o conto "ao longe, êêe da molecada jogando pelada, cicio das mulheres recolhendo roupa no quarador, ì̀n-nhô! de uma mãe conclamando o filho, vrum de um carro, risos abafados...” (RUFFATO, 2006, p. 45) é o mesmo que o encerra, de forma a chamar a atenção para a forma circular, sem saída e não-evolutiva dessa história, em que estão aprisionados tanto os personagens da saga, quanto grande parte da nação.

\footnotetext{
${ }^{22}$ Trecho da peça teatral Singular, de Ferreira Gullar. In: http://pt.scribd.com/doc/77806670/Gullar-Singular. Acesso em junho de 2012.
} 
O protagonista Caburé é frequentemente espancado pelo pai, Zé Bundinha personagem que no volume dois de Inferno provisório interrompe o sonho de Hélia batendo na esposa, D. Fátima -, e assim como muitos meninos da saga, desejava que a "íngua" do pai morresse. "Como respeitá-lo, descendo trôpego o Beco, chegando carregado da rua desoras?” (RUFFATO, 2006, p. 47). Ansiava cicatrizar os lanhos das costas, braços, pernas e rosto deixados pelo punho paterno, cuja cartilha graduava "beliscão, puxão-de-orelha, lambada de vara de marmelo na bunda e, nas gravidades, coça de corrião" (Idem, 45).

O moleque decide fugir e assumir de vez a condição de renegado: nunca mais sentar numa carteira de escola, escovar os dentes ou tomar banho diário, mas principalmente, "nunca mais apanhar do pai, sentir o hálito azedo de cachaça e cigarro nunca mais" (p. 48). No fundo do embornal, assentou "pão-com-manteiga, biscoito-de-maisena, vidro de água, e galgou discreto as escadas do Beco, resoluto, a garganta latejando uma antecipada saudade". Ao se afastar de casa, o desenrolar dos dias deixados para trás não lhe sai da cabeça:

\begin{abstract}
A essa hora, Zé Pinto cochila ao sol, sob o pé-de-amêndoa, em frente ao botequim, mosquitos lambem as quitandas destampadas do balcão; seu Antônio português esfrega o passeio da Mercearia Brasil, calças arregaçadas; cismado, Zunga se esgueira, o bloco de anotação do jogo-do-bicho enfiado no cós da calça, sob a camisa; Hilda do Zito Pereira refoga a couve, manhosas meninas de nariz estilando agarradas às pernas; dona Zulmira carrega um caldeirão-de-comida para o seu Marlindo; debruçada no muro, dona Olga relata outra noite sem dormir, passos, conversas, latidos, miados, pios, 'Tudo incomoda, Sá-Ana, tudo, estou ficando doida! (Idem, p. 49)
\end{abstract}

A pasmaceira em que transcorrem os dias que transcorre na pequena cidade mineira o anestesia até descobrir, abobado, que a água entornara do vidro, encharcando o pão com manteiga dentro do embornal. Revoltado, resolve que ainda assim marcharia, mas na primeira curva divisou direção contrária, e reentrou de chofre na casa dos pais para novamente ver abortados os seus planos. A ideia de vender picolés com o amigo Fábio é também malograda, quando, ao receber do pai um pontapé no traseiro que destampa o isopor, vê “igrejos picolés voarem pelos ares" (Idem, p. 50).

A cada episódio é um da capo: “Ao longe, ê-ê-ê da molecada jogando pelada, cicio das mulheres recolhendo roupa do quarador, ííi-nhô! de uma mãe 
conclamando o filho, vrum de um carro, risos abafados...De coque, Caburé cafunga, doloridos lanhos nas costas, braços, pernas, rosto" (Idem, p. 51). Tudo volta a ser como sempre foi, sem nenhuma mudança transformadora.

Se a literatura de Oswald de Andrade nos anos 1920, tentava contornar o nosso atraso histórico recorrendo ao conceito de utopia e ao pensamento mítico "que conferiam sentido à nossa marginalidade e impregnavam de esperança aquela constante sensação de andarmos em círculos", como observa Vera Follain de Figueiredo no ensaio Da profecia ao labirinto (1994, p. 34), pode-se dizer que O Inferno provisório funciona como um círculo vicioso, sem saída, dominado por um esquema repetitivo, tecendo uma imagem da nossa história que não contempla dimensão de futuro, sugerindo uma circularidade estéril.

A ficção de Luiz Ruffato, observa Marcos Vinícius Ferreira de Oliveira, embora leve em consideração a possibilidade de o escritor intervir no equilíbrio da sociedade, ao sugerir o descompasso das 'virtualidades retrógradas da modernização',

não é, sob hipótese nenhuma utópica. Antes, seria distópica talvez, pois não vemos os conjuntos narrativos, que são os cinco volumes de Inferno provisório, acenarem com a possibilidade de que possa haver uma superação dos limites impostos pela estrutura socioeconômica que os enreda (OLIVEIRA, 2013, p. 169).

Em contraste com outras versões da história, de caráter monumental e que optam por um modo de representação linear e uniforme do passado, aqui, as várias entradas disponíveis garantem acesso aos diversos "corredores". Os princípios estruturais de Inferno provisório acentuam a diversidade, a complexidade e a contradição, portanto, formas avessas a perspectivas globais, homogeneizantes e que prometem uma totalidade.

Com suas histórias, Ruffato privilegia uma representação sincrônica, isenta de sequencialidade e incompatível com as ideias de coerência e síntese, oferecendo múltiplas possibilidades de ordenação do processo de leitura. O episódio Zezé e Dinim, por exemplo, que encerra O livro das impossibilidades, quarto volume da série, narra as trajetórias dessas personagens, a partir de seus 
nascimentos e fá-las correrem paralelas na própria mancha gráfica, à maneira de colunas de jornal ou revista. À esquerda, a vida de Zezé, filho do alcóolatra Matias e da zelosa Nazaré; à direita, a vida de Dinim, filho do negligente Afonso e da "hospicida, queimadeira de dinheiro" Iracema ${ }^{23}$, (RUFFATO, 2008, O livro das impossibilidades, p. 101). Vez por outra as histórias se misturam e o texto também, potencializando a ideia de história sincrônica.

Nascidos em 1960, os amigos, de "perrenguice em perrenguice”, vão levando a vida. Zezé cresce acostumado com as "mãos intolerantes da mãe, que o atingiam abertas as nádegas por qualquer nada" e com os "braços verdugos do pai, que com a tomada do ferro-de-passar-roupa ou o cabo-de-vassoura ou o corrião ou coisa-qualquer à mão, enfiava o couro" (Idem, p. 97). Já Dinim, cresce mimado pelas tias em idade-de-casar, entre "ais e uis, tchuco-tchuco-tchucos, zu-zu-zu-zus e ne-ne-nes" (Idem, p. 95). Alunos da mesma escola, de tudo desassistidos, "empregocasaescolacolegasmãefamiliasossego: tudo" (Idem, p. 99), vivem a pensar "feliz do Dinim", "feliz do Zezé” (Idem, p. 101) sem se darem conta de que o problema de um é também o problema do outro. No emblemático ano de 1968, a professora D. Darcy equilibra com desvelo o retrato do general Costa e Silva,

verdeamarela faixa, alunos enfileirados, Hora Cívica, Ouviram do Ipiranga às margens plááácidas, esganiçadas vozes, acumuladas fomes, meio dia cozinhando cabeças, duas vezes Zezé desmaiara, outro tempo, firma-se então, berros, José Teixeira Pedro!, puxões de orelha, José Teixeira Pedro!, espancamentos, Fedamãe!, estuda não, é? Vai ver só!, esculachos, Tão pobrim, nem comida em casa, tadim! Ansiosa, a mão direita ouve o coração. À frente, Dinim, fortudim, saliente, De um poveróico brado retumban-tí (Idem, p. 99-100).

A narrativa acumula fragmentos de uma realidade nacional nada cívica, na qual a fome, a violência doméstica, a miséria, o alcoolismo, a falta de qualificação profissional, a urbanização desenfreada e a consequente escalada da violência se entrelaçam aos idealizados símbolos da ordem e do progresso.

\footnotetext{
${ }^{23}$ Proposital ou não a escolha do nome Iracema soa como uma ironia à personagem que dá título ao romance homônimo de José de Alencar, a virgem dos lábios de mel que gerou Moacir (fillho da dor), o primeiro brasileiro.
} 
Dois anos depois, o grande dia. "O mundo se esgoelando em foguetes, os canarinhos volteando o Estádio Azteca" para a final da Copa de 1970 ao som de "a taça do mundo é nossa / com o brasileiro / Não há quem possa”, enquanto isso,

na Mercearia Brasil, o seu Antônio Português hospedou uma televisão nova, Colorado RQ, para a freguesia acompanhar a Copa do Mundo; gentes se esparramavam, passeio e meio da rua, entravando o tráfego dos cataníqueis e dos enfeitados carros que desfilavam buzinas e bandeiras (Idem, p.106)

De silêncio em silêncio, de cruzamento em cruzamento, de cabeçada em cabeçada "a bola para a rede, desconsolando o goleiro Albertosi um raio irrompe do quarador celeste alcançando justo um gato estendido em sonhos no parapeito da janela consumindo toda uma vida Gooooooooooooooooooooool! Brasil um a zero!” (RUFFATO, 2008, O livro das impossibilidades, p. 108). No intervalo, retalhos de infindas discussões reforçam a escolha pela escrita fragmentada: "Zagalo tinha que tirar o...Riva é que é um...porra nenhuma, é só...pela esquerda" (Idem, p. 108).

De volta ao jogo, novo silêncio, "um deserto de respirações". Gérson arremata a bola que se aloja "no canto esquerdo de Albertosi Gooooooool! Brasil dois a um! eu te amo meu Brasil, eu te amo / meu coração é verde, amarelo, branco, azul anil” (2008, p. 108). Cinco minutos mais tarde, Canhotinha de Ouro, toca para Pelé, que toca para Jairzinho para enviá-la ao fundo da rede "Puta merda! Puta merda! É goooooooooooooool! É gooooooooooooooooooooooooool! É goooooooooooooooooooooool! Brasiiiiiiiiil! Três a um!” (Idem, p. 109).

Mas a alegria de campeão do mundo dura pouco para o pai de Zezé. “Corrido em dívidas, cachaçada e jogatina", Matias deixa Cataguases com a prole rumo ao Rio de Janeiro para viver numa favela no bairro da Cacuia, Ilha do Governador. Vem a trabalhar na construção da ponte Rio-Niterói, símbolo máximo dos feitos da ditadura militar. 
Maior ponte do mundo. Com treze mil e duzentos e noventa metros de extensão - sendo oito mil oitocentos e trinta e seis metros sobre o mar - vinte e seis metros e sessenta centímetros de largura, seis faixas de acostamentos, e a altura máxima de setenta e dois metros acima do mar, pode ser considerada sem exagero a Oitaaaava Maraviiiilha do Muuuuundo! (v. 4, p. 112)

A areia empregada na construção da ponte daria para "enterrar a metade da praia de Copacabana" ou o cimento usado "mais de quatro milhões e seiscentos mil sacos - se deitados fariam mil e quinhentas pilhas da altura do Pão de açúcar?" (Idem, p. 113). Mas, finda a construção da oitava maravilha do mundo, envolvida em denúncias de superfaturamento, Matias, "traste sem serventia", retoma a sua vida sem horizontes, acampando no botequim

\begin{abstract}
labirintava enojado pelos estreitos becos da favela, túrgido graveto de pele turva, de Bandeira apelidado, crueldade do povo, porque trêmulo, todo o tempo ao vento submisso, caquético, bruxelando desesperado, vazando por todos os poros o homem que um dia havia sido, até concluir-se murundu pobrinho arruinado no cemitério da Cacuia, vencido pela cachaça (RUFFATO, 2008, O livro das impossibilidades, p. 136).
\end{abstract}

Despejados da casa da Cucuia, Zezé e família escalam para um barraco nauseante no Morro do Dendê, "os nove soçobrando na imundice dos ratos baratas mosquitos" (Idem, p. 136) sonhando outra vida, ser rico ou jogador de futebol, a solução sempre "Deus ex machina”, que já aparecera no episódio "A solução" (O mundo inimigo, 2006).

Dinim casa-se com Vilma. Embora arquitetassem filhos, "Uns três, já pensou? Dois dininzinhos, uma Vilminha...”, quando a menstruação falhou, o drama: "Como vamos fazer para cuidar de um bebê, se nem emprego eu tenho?" (Ibidem). Decidem procurar uma colega que lidara com assunto semelhante:

toma quatro Cytotec e enfia mais uns três, quatro na...na vagina você vai sentir como se estivesse com dor-de-barriga, sabe?, aí vai descer uma sangueira danada e...bom, aí você procura um médico no pronto socorro, fala que teve um sangramento, ele vai examinar, vai falar que você teve foi um aborto, vai perguntar se você que provocou, você claro vai dizer que não, jurar que não, ele vai fazer a curetagem, e aí acabou... (Idem, p. 137). 
O malogro está por toda a parte, seja no aborto clandestino, na morte prematura dos pais, na migração frustrada. Zezé ansiava por um emprego, mas, a falta de qualificação profissional, documentos, indicação, experiência, fazia com que amargasse filas e empacasse na empreitada.

Bombeiro exigia cabeça, pintor capricho, eletricista curso, mecânico conhecimento, representante comercial mais que a sexta série incompleta. Biscateou: porteiro noturno de edifício, ajudante de serviços gerais, lavador e guardador-de-carro, vendedor de picolé, de empadinha, de milho, de camarão no Leme (Idem, p. 140-1)

O aluguel atrasado, a comida de xepa, a roupa de bazar beneficente. Às vezes enfezava-se, com vontade de aceitar o "três-oitão" e perder-se por aí.

O olhar de desprezo do filhinho de papai, bum! O chute de humilhação do bacana do prédio um-por-andar, bum! O arrepio de nojo das garotas bronzeadas que passam o dia de bunda para cima na praia, bum! (RUFFATO, 2008, O livro das impossibilidades, p. 141).

Mas, na falta de coragem, distribuía filipetas de restaurantes em Copacabana em troca de uns poucos caraminguás. Enquanto isso, Dinim amarga um bom tempo na Cadeia de Muriaé. Preso por transportar para o patrão um carregamento sem nota. De trás das grades, soube que o patrão, cínico, confirmou ser dele o veículo, mas "meu deus, estava arrendado para este rapaz...como podia adivinhar, santo Deus! Que mundo o que vivemos!” (Idem, p. 139).

“Afundemos mais um pouco, baby" (Idem, p.141). Livre das grades, Dinim aceita guardar drogas para um traficante conhecido, até que vem a batida policial. "Todo mundo parado aí" (Idem, p. 142). Na manhã feriada, dia da Independência, "enquanto bermudas esguichando água na lataria de carros, saias varrendo passeios, vozes cervejando botequins...frenéticas bandeirolas verdamarelas alto falante Palmas! Vamos saudar os nossos recrutas!" (Idem, p. 142), em fuga, Dinim rola telhados, desaba envergando hastes de toldos e tomba sobre folhas ajuntadas rente ao meio fio. "Fugir nem tenta, esfolados braços, joelhos, cotovelos" (Idem, 143). Algemado, é jogado ao camburão de encontro à cara derrotada de Vilma. Aos poucos, à multidão se dissolve, mistura-se a "estudantes 
azul-e-branco que regressam da parada do Sete de Setembro, suados, claudicantes, felizes" (Idem, p. 143).

O episódio ilustra o que o crítico hindo-britânico Homi Bhabha chama de duplicidade do tempo nacional. De um lado, uma temporalidade pedagógica, que insiste nos símbolos continuístas e homogeneizadores de uma sociedade horizontal - a hora cívica, a seleção brasileira, os desfiles militares -, e um outro performático, que admite a "presença perturbadora de uma outra temporalidade que interrompe a contemporaneidade do presente nacional” (2010, p. 203), representado pelo crescimento desordenado, a falta de oportunidades e a escalada da violência. Segundo o autor, é "somente no tempo disjuntivo da modernidade da nação - como um saber dividido entre a racionalidade política e seu impasse, entre os fragmentos e retalhos de significação cultural e as certezas de uma pedagogia nacionalista - que questões da nação como narração vêm ser colocadas" (Idem, 202).

Ao reescrever a sua história do Brasil, Ruffato desmonta a visão holística do passado nacional. Ele introduz a temporalidade do entre-lugar, desestabilizando o significado de povo homogêneo e mostrando que "estamos diante da nação dividida no interior dela própria, articulando a heterogeneidade de sua população" (BHABHA, 2010, p. 209). A ideia de uma história sincrônica - que permite acontecimentos simultâneos no espaço e no tempo -, descompassada, inconclusa e protagonizada por anônimos personagens destituídos de heroísmos e tragicamente marginais à cronologia, perpassa os cinco volumes de Inferno provisório. "Histórias que são e não são parte da História do Brasil. Histórias fora da ordem e do progresso" (RUFFATO, 2004, p. 11), reforçam a ideia de Caetano Veloso, na canção Fora da Ordem, de que "aqui, tudo parece que ainda é construção e já é ruína". 


\title{
5. Considerações finais
}

\author{
Os problemas brasileiros de hoje, os \\ fundamentais, pode-se dizer que já estavam \\ definidos e postos em equação há 150 anos \\ atrás. \\ [Caio Prado Júnior em Formação do Brasil \\ contemporâneo (1942, p. 1127)].
}

A canção Pedro Pedreiro (1965) de Chico Buarque fala do desespero de diversas gerações de Pedros que não têm vintém, numa infindável expectativa por dias melhores: à espera do trem, da manhã, do Carnaval, do sol, de um bilhete premiado, de um aumento no mês que vem, de uma festa, da morte ou da sorte que nunca vem. Vinte e um anos depois, a canção Alagados, dos Paralamas do Sucesso, também toca no tema da delonga de uma "esperança que não vem do céu, nem das antenas de TV", mas da "arte de viver da fé". O romance Domingos sem Deus (2011), que encerra a saga Inferno provisório, tem em seu próprio título um indicador que coloca em xeque a própria ideia de viver de fé na nossa atual conjuntura. Teríamos perdido o bonde da esperança?

No ensaio A nova questão social brasileira, de 1998, a professora de Sociologia da USP Vera da Silva Telles, afirma que durante décadas a nossa pobreza figurou como um sinal de atraso que haveria de ser superado pelas forças do progresso, mas que no momento parece se fixar "como realidade inescapável, dado incontornável posto pelos imperativos do mercado em tempos de aceleração econômica e revolução tecnológica" (p.107). Nessa virada de milênio, quando escreve a professora, imperam imagens de uma "pobreza sem redenção" (Ibidem).

O documentário Encontro com Milton Santos ou: O Mundo Global visto do lado de cá (2006), de Silvio Tendler, mostra que a fase da Globalização iniciada no final do século XX, é caracterizada pelo desmonte do estado e do bem estar social, no qual o consumo voraz - "o grande fundamentalismo" do século substitui o humanismo como motor do desenvolvimento e do progresso. $\mathrm{O}$ geógrafo considera, no entanto, que há de três tipos de Globalização: a primeira do mundo da fábula, a existência do mundo como nos querem fazer ver; a 
segunda, do mundo tal como ele é, perverso; e a terceira, como ela poderia ser. Mas de fato, segundo Santos, "para a grande maioria da humanidade, a Globalização está se impondo como fábrica de perversidades", gerando desemprego crescente e crônico, aumento da pobreza, perda da qualidade de vida para a classe média, diminuição do salário médio, fome e desabrigo generalizados em todos os continentes. Cada vez trabalha-se mais e com menos direitos, o desemprego torna-se normal e a pobreza passa a ser tratada com "naturalidade".

As personagens de Ruffato, que ao longo dos cinco romances fugiram de sua história e de seu passado atrás de um "pote de ouro" que estaria nos grandes centros urbanos, fazem parte dessa engrenagem e encontram-se esgotadas. A massa de trabalhadores recrutada pelo aquecimento econômico a partir da década de 1950, está à deriva, entregue às forças cegas do capitalismo sem freios e do desenraizamento. As noções de direitos e cidadania que foram formulados como promessas da modernidade, e que nem chegaram a se efetivar, aparecem no fim da década de 1990 e início dos anos 2000 como o seu avesso: como atrasos, anacronismos, privilégios e corporativismos que impedem a "modernização do mercado" (TELLES, 1998, p.108).

O que o autor mineiro mostra é que para os desempregados e excluídos que não tem lugar na atual fase do capitalismo globalizado, a sua pobreza é apenas a evidência de sua "incapacidade" de se adequar ao progresso contemporâneo. Esses "inempregáveis" - para usar o termo cunhado por Vera da Silva Telles -, de Inferno provisório, sem qualificação ou competência, que se tornaram dispensáveis para o atual ciclo da modernização brasileira, assim como as naus de Jorge de Lima não chegaram a lugar nenhum e tampouco têm para onde voltar.

Esse sentimento de esses nossos "Pedros" estarem num beco sem saída, à deriva, tópico caro à literatura contemporânea de sujeitos sem identidades fixas, aparece em Ruffato de maneira singular, como a metáfora de um processo histórico nacional que patina. O autor volta ao Brasil rural na década de 1950 para mostrar o quanto os nossos problemas de hoje já estavam postos desde então. Não há uma bandeira essencialista que aponte para aspectos do passado histórico ou interior longínquo a serem recuperados. Pelo contrário, o passado em Inferno provisório - representado em Mamma son tanto felicce (que remete aos anos 
1950) - é tão precário quanto o presente - representado em Domingos sem Deus (que se passa já na virada do milênio).

Passam-se os anos, as décadas, modernizam-se os bens, mas a sociedade continua desassistida como sempre, só que cada vez mais desarticulada. O projeto literário de Luiz Ruffato dramatiza então os 50 anos do engodo de uma modernidade - ou da comédia de um progresso - que desenraiza, desagrega, desemprega e descarta as populações. Pode-se dizer, no entanto, que duas coisas assumem constância desde o Brasil colônia até o neoliberalismo: a conservação dos privilégios nas mãos de poucos e a carência das prerrogativas básicas de cidadania para as massas. Darcy Ribeiro em $O$ povo brasileiro já apontava para essa questão:

\begin{abstract}
Nada é mais continuado, tampouco é tão permanente, ao longo desses cinco séculos, do que essa classe dirigente exógena e infiel a seu povo...Tudo, nos séculos, transformou-se incessantemente. Só ela, a classe dirigente, permaneceu igual a si mesma, exercendo sua interminável hegemonia (1995, p. 69).
\end{abstract}

Para Darcy, o Brasil passa de colônia a nação independente e de Monarquia a República, "sem que a ordem fazendeira seja afetada e sem que o povo perceba" (Idem, p. 219), de modo que o estado apresenta mais continuidades do que rupturas.

Laurentino Gomes lembra no ensaio 1808 que viajantes estrangeiros, como James Henderson, em seus relatos já chamavam a atenção para o analfabetismo, a falta de cultura e instrução da sociedade local no século XIX. Para o inglês, essa ausência era consequência da proibição geral de circulação de livros e a falta dos mais elementares meios pelos quais os habitantes do Brasil pudessem tomar conhecimento do mundo e do que se passa nele. Aqui, os habitantes estariam mergulhados em grande ignorância e sua consequência natural era "o orgulho" (In: Gomes, 2007, p. 238). Caio Prado Júnior em Formação do Brasil Contemporâneo, de 1942, corrobora o pensamento de Henderson. O historiador conta que os depoimentos dos viajantes do século XIX eram frequentemente de flagrante atualidade: "quem percorre o Brasil de hoje fica muitas vezes surpreendido com aspectos que se imagina existirem nos nossos dias unicamente 
em livros de história; e se atentarem para eles; verá que traduzem fatos profundos e não apenas reminiscências anacrônicas" (2000, p. 1127), ou seja, os problemas brasileiros de hoje, como aparecem nos cinco romances de Inferno provisório, nos acompanham desde sempre.

Esses "efeitos perversos" do passado colonial que, apesar das transformações do país, prolongam-se nos séculos XX e XXI, somados às tendências da Globalização neoliberal, fazem com que os pobres de agora (outrora escravos) tenham outros senhores e sejam cada vez mais dependentes dos rumos do dinheiro e extremamente suscetíveis aos fluxos da riqueza, que os levam a reboque, de um lado para o outro.

No discurso proferido na Feira do Livro de Frankfurt, em 2013, Ruffato lembra que desde a abolição da escravatura, em 1888, não houve qualquer esforço no sentido de possibilitar condições dignas aos ex-cativos. "Assim, até hoje, 125 anos depois, a grande maioria dos afrodescendentes continua confinada à base da pirâmide social: raramente são vistos entre médicos, dentistas, advogados, engenheiros, executivos, jornalistas, artistas plásticos, cineastas, escritores"24.

Essas raízes do Brasil aparecem em Inferno provisório como um obstáculo para a modernização. O passado aparece na contemporaneidade nacional como uma "aparição fantasmal”, reciclando a herança romântica como resíduo, como coloca Renato Cordeiro Gomes, no artigo Heranças, espectros, resíduos: imaginar a nação em tempos heterogêneos. A imagem espectral da nação ressuscita, para Gomes, sob o signo da casa assassinada - metáfora retirada do título do romance de Lúcio Cardoso (1959), que trata da decadência de uma família patriarcal mineira - perambulando na memória de gerações como uma herança ora rejeitada, ora reivindicada por várias filiações $(2014$, p. 47).

Inferno provisório reúne histórias de decadência, de casas assassinadas, de esterilidade e assume a herança de interpretar o Brasil, abrindo mão de uma estratégia totalizadora e pedagógica de um imaginário coercitivo e unificador, para lidar de modo performático com o espectro da nação, "em que esta se torna

\footnotetext{
${ }^{24} \mathrm{http}$ ///cultura.estadao.com.br/noticias/geral,leia-a-integra-do-discurso-de-luiz-ruffato-naabertura-da-feira-do-livro-de-frankfurt,1083463 (Acesso em 07/06/2014).
} 
um espaço liminar de significação em que a própria herança cultural se desestabiliza, porque não mais homogênea, agora marcada pela temporalidade do entre-lugar" (Idem, p. 51).

O discurso sobre a nação em Ruffato propõe que a redenção não está no passado remoto ou no interior longínquo e tampouco na dispersão para os grandes centros ou para fora do país, como mostra em Estive em Lisboa e lembrei de você (2009), mas pelo reconhecimento de um outro historicamente negado. Em seu pronunciamento de Frankfurt, Ruffato deu uma importante chave de leitura para sua obra: a de que a história do Brasil foi alicerçada quase que exclusivamente pela negação explícita do outro por meio da violência e da indiferença. Esse outro imigrante, pobre, negro, desempregado, alcoólatra, descartado pela sociedade acaba por sucumbir numa estranha sensação de não-pertencimento. "Como não enxergamos o outro, o outro não nos vê. E assim acumulamos ódios - o semelhante torna-se inimigo" 25 , sentenciava.

Assim, a competição exacerbada, selvagem, transforma a violência num recurso cotidiano para a sobrevivência. No entanto, "uma sociedade que não dá valor à vida não pode pretender que os excluídos, do emprego, da escola, da vida familiar, considerem a vida um valor. A violência é, também, resultado da progressão avassaladora do individualismo das massas", apontam João Manuel Cardoso de Mello e Fernando A. Novais, em A que ponto chegamos, balanço escrito na virada do milênio (1998, p. 13).

Ao revolver a impossibilidade de dar certo no rumo em que estamos, o autor mineiro nos convoca a pensar nos efeitos destrutivos tanto do passado quanto da espera incessante por dias melhores, sem que nada de verdadeiramente transformador se faça e aconteça. Em sua saga, não cabe pensar que somos um país novo, um "país do futuro", para ficarmos esperando soluções milagrosas tipo Deux ex machina. Tampouco a fuga do nosso passado - seja pela negação e/ou migração - vai fazer com que sejamos uma nação verdadeiramente moderna. $\mathrm{O}$ medo de olhar para o que somos dá origem a periódicos rompantes de entusiasmo injustificado.

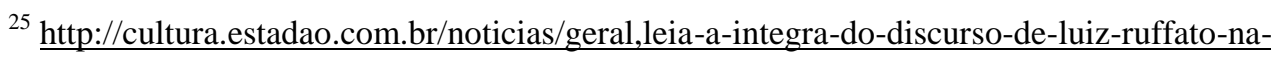
abertura-da-feira-do-livro-de-frankfurt,1083463 (Acesso em 07/06/2014).
} 
"Eu lembro de tudo e isso machuca a gente", diz a personagem Dinim ao amigo Zezé, n'O livro das impossibilidades (RUFFATO, 2008, p. 151). Se lembrar o passado é desconfortável, apagá-lo tampouco faz do Brasil um lugar melhor para se viver. Assim, Inferno provisório faz da estrutura literária uma moldura para interpretar o país, diferente do projeto romântico - que cria mitos e heróis que funcionam como ‘cimento ideológico’ para a edificação da nação - e da proposta modernista - na qual existia uma consciência de nosso atraso e um tom crítico a respeito de nossa história, mas guardava uma utopia, acreditava num projeto modernizador para o país.

O projeto de Ruffato de escrever cinco romances sobre a formação do nosso proletariado parece, à primeira vista, uma reciclagem anacrônica do modernismo. De um lado porque o discurso sobre "formação" é hoje um dado "agônico" que está sendo substituído pelo discurso da "inserção", conforme propõe Silviano Santiago $^{26}$. De outro, soa como um projeto 'monumental', que visaria revisitar os últimos 50 anos da história nacional para apresentar propostas para o futuro do país. No entanto, tanto a forma, quanto o conteúdo da pentalogia como observamos ao longo dessa tese, rasuram o sentido de imagem 'única' e 'totalizante' do passado e ainda de um sentido da utopia.

De acordo com Flávio Carneiro no ensaio No país do presente: ficção brasileira no início do século XXI, estaríamos vivendo um tempo 'pós-utópico', reportando-se ao termo criado por Haroldo de Campos ${ }^{27}$. O 'princípio-esperança' e o espírito combativo que teriam marcado o imaginário modernista, voltado para o futuro, são substituídos pelo 'princípio-realidade', centrado no presente (CARNEIRO, 2005, p.18). Há, para este ensaísta, o deslocamento de um imaginário marcado pelo desejo de mudança radical e por uma visão otimista do futuro, para um outro imaginário, no qual não há projetos grandiosos, mas apenas projetos particulares focados no desenrolar minucioso do dia-a-dia.

\footnotetext{
${ }^{26} \mathrm{http}: / /$ cultura.estadao.com.br/noticias/geral,formacao-e-insercao-imp-,878251. Acesso em $06 / 07 / 2014$.

${ }^{27}$ CAMPOS, Haroldo de. "Poesia e modernidade: Da morte do verso à constelação. O poema pósutópico, Folhetim da Folha de S. Paulo, 7 e 14/10/1984.
} 
Se já não cabe mais falar no 'princípio-esperança', que norteou os projetos da modernidade, no sentido de que não faz mais parte do nosso imaginário a crença em grandes empreendimentos redentores, há, por outro lado, algum vislumbre de uma nova trilha: a da incerteza, dos pequenos projetos, da incompletude (Idem, p. 29).

Inferno provisório surge pois, tão somente, da necessidade pessoal de representação da realidade nacional de um determinado ponto de vista, o do autor, e não obedece a um programa ou um projeto orientador.

A leitura descompromissada de algumas opiniões pinçadas ao acaso em jornais, revistas, ensaios e mídias digitais, revelam que há uma generalizada falta de consenso sobre a imagem do país. Seja porque estaríamos vivendo tempos de crise das grandes ideologias e utopias, seja pela revolucionária experiência da Internet, ferramenta que democratiza o direito à palavra.

De achismos a opiniões contundentes ou polêmicas, observamos ideias das mais variadas. Para Zuernir Ventura e Domênico Di Mardi, por exemplo, o país estaria vivendo uma "onda de mau-humor" "sem motivos", uma vez que podemos servir de modelo de vida 'universal' por conta de nossa miscigenação, sabedoria, beleza, harmonia e ainda por nossa "vocação para a alegria" ( $O G L O B O$, 04/06/2014). Já Arnaldo Jabor traça um quadro pessimista: a camaradagem e a hospitalidade estariam dando lugar à violência: ônibus queimados, presos massacrados, "uma revolta sem rumo", um rancor geral contra tudo e contra todos, de modo que o Brasil estaria com "ódio de si mesmo" ( $O$ Globo, 06/05/2014). A solução para ele seria tirar do poder "esses caras que se julgam os sujeitos da história. Até que são mesmo, só que de uma história suja e calamitosa" (O Globo, 06/05/2014, p. 10). Para o jornalista Luciano Trigo, "sem valores básicos comuns, sem uma ética dissociada de interesses políticos, sem noções compartilhadas de certo e errado, nenhuma sociedade pode prosperar" (O Globo, 22/03/2014).

A pluralidade de vozes, de interpretações e de desejos com relação ao país, marcou as manifestações que tomaram as ruas do país em 2013 e acabaram por fornecer elementos para que a grande imprensa e o Estado tomassem os protestos como enfraquecidos. As manifestações trouxeram à tona temas públicos, nem sempre novos, mas indispensáveis como a corrupção, a crise de representação, os 
problemas de mobilidade urbana, de educação e de saúde e pode ser entendida como um sintoma dos benefícios acumulados nos últimos anos: estabilidade política, econômica e liberdade de expressão.

Se as manifestações mostraram que não é possível 'acordar o gigante', uma vez que o caráter de coletividade e interesse em comum para o país perdeu as suas diretrizes, por outro lado ela deixa um legado importante: a possibilidade de renovação dos agentes públicos, de construção de uma democracia ativa e de nos tornarmos seres mais plenos no exercício da política e da cidadania. Creio, no entanto, que a imprensa, ao generalizar os manifestantes como meros instrumentos no jogo da grande política, colaborou, de certa forma, para que o país perdesse a chance de se repensar em novos termos, pela via da articulação das diferenças. Como bem pontua Stuart Hall, em A identidade cultural na pósmodernidade, "a identidade plenamente unificada, completa, segura e coerente é uma fantasia". Em tempos pós-modernos "somos confrontados por uma multiplicidade desconcertante e cambiante de identidades possíveis" (HALL, 2006, p. 13).

A modernidade tardia tem como característica um processo "sem-fim de rupturas e fragmentações internas" e não têm "nenhum centro, nenhum princípio articular ou organizador único e não se desenvolvem de acordo com o desdobramento de uma única 'causa' ou 'lei'” (HALL, 2006, p. 16). Sendo assim, as sociedades pós-modernas deixaram de ser entendidas como

um todo unificado e bem delimitado, uma totalidade, produzindo-se através de mudanças evolucionárias a partir de si mesma, como o desenvolvimento de uma flor a partir de seu bulbo. Ela está constantemente sendo 'descentrada' ou deslocada por forças fora de si mesma (HALL, 2006, p.17)

As sociedades da modernidade tardia são, então, caracterizadas pela diferença e atravessadas por diferentes divisões e antagonismo sociais e, se não se desintegram totalmente, não é porque elas são unificadas, mas porque seus diferentes elementos podem ser conjuntamente articulados. 
O quadro de pessimismo traçado por João Manuel Cardoso de Mello e Fernando A. Novais no ensaio de 1998, bem como a imagem de uma "pobreza sem redenção" construída pelo escritor mineiro em Domingos sem Deus, que se estende ao limiar do século XXI, ganha novos contornos agora. O comentário final de Milton Santos no documentário de Silvio Tendler bem como discurso de Ruffato em Frankfurt em 2013, soam como uma nesga de otimismo.

Para Milton Santos, a Globalização em sua versão "totalitária" e "perversa" estaria com seus dias contados. As populações desassistidas se agitam em prol de formas de produção e distribuição de renda verdadeiramente democráticas. A grande novidade do momento seria para ele a "revanche da periferia". Ele acredita na ideia de que outra realidade é possível, sendo pessimista com relação ao passado, mas otimista em relação ao que pode vir. Para ele, a presença de um Estado socializante capaz de equilibrar os efeitos perversos das diferenças e desigualdades é fundamental.

Ruffato, embora lamente que ainda soframos com o legado de "500 anos de desmandos", reconhece que o país tem avançado com o reestabelecimento da democracia, a estabilidade política e econômica, as conquistas sociais. Para ele é inegável “a importância da implementação de mecanismos de transferência de renda como as bolsas família, ou de inclusão, como as cotas raciais para ingressos nas universidades públicas" que vêm trabalhando para reduzir a miséria no país.

A consolidação da democracia no país, somada a contenção do neoliberalismo sem freios permitiria que pudéssemos finalmente cultivar uma "política da esperança" - o que para a crítica literária Beatriz Resende não quer dizer que tenhamos uma "aceitação unânime das políticas de estado, tampouco ausência de manifestações de descontentamento". Para a autora, estaríamos passando de país unicamente receptor para país fornecedor, com capacidade de nos organizarmos democraticamente e afirmar as nossas vozes. O surgimento de uma "nova classe média" e de novas subjetividades que emergem das periferias das grandes cidades brasileiras, assim como a literatura de Luiz Ruffato, vem finalmente rebater a exclusão social através de uma literatura compromissada e conjuntural como alternativas para enfrentar os efeitos da globalização neoliberal. 
A globalização coloca Néstor Gracía Canclini em Consumidores $e$ Cidadãos, é uma tendência irreversível. O global, no entanto, não é necessariamente o substituto do local e tampouco o modo neoliberal de nos globalizarmos é o único possível. Portanto, a reivindicação do debate sobre as singularidades nacionais e formas não-hegemônicas de representação da realidade nacional não tem em Ruffato o cunho essencialista. Trata-se de propor um debate sobre aqueles que foram "varridos" da história nacional para debaixo do tapete e que agora, diante da estandardização cultural, são mais uma vez banidos. O debate sobre a dignidade e civilidade, respeitando as diferentes culturas, não exclui pensar uma sociedade solidariamente globalizada.

A História feita por papéis, diz um cego em Viva o povo brasileiro, de João Ubaldo Ribeiro, “deixa passar tudo aquilo que não se botou no papel e só se bota no papel o que interessa" (1984, p. 515). O que Luiz Ruffato se propõe é pegar de pena e tinteiro, ou melhor, o computador, para botar no papel um pouco daquilo que ficou de fora: a história dos vencidos. É um macro romance que abre mão do resgate de uma verdade única sobre a formação das desigualdades brasileiras. Escrito com as sobras da história, com aquilo que a história oficial rejeitou, expeliu, empurrou para a margem. É um romance que desinventa as formas de pensar homogeneizantes tanto no âmbito nacional quanto no âmbito global. Instiga a pensar que o apagamento da própria história pessoal, familiar, nacional ou global não nos torna mais felizes. Reivindica, em sintonia com o pensamento de Milton Santos, que temos que retomar o debate da cidadania que a gente abandonou quando passamos a discutir o crescimento econômico. 


\section{Referências Bibliográficas}

AHAMAD, Aijaz. Retórica da alteridade de Jameson e a "alegoria nacional". Novos Estudos, Cebrap. São Paulo, no. 22. Out. de 1988.

ALENCAR, José de. "Benção paterna". In: Sonhos d'ouro. São Paulo: Ática, 1981.

Como e porque sou romancista. Disponível em: http://www.dominiopublico.gov.br/download/texto/bv000311.pdf Acesso em: maio de 2012.

ANDERSON, Benedict. Comunidades imaginadas. São Paulo: Companhia das Letras, 2008.

ANDRADE, Mário. "O movimento modernista”. In: Aspectos da literatura brasileira. São Paulo: Martins, 1974.

ASSIS, Machado. Notícia da atual literatura brasileira: instinto de nacionalidade. In: Obra completa da Machado de Assis. Rio de Janeiro: Nova Aguilar, v. 3, 1994.

BAPTISTA, Abel Barros. A formação do nome: duas interrogações sobre Machado de Assis. Campinas: Editora Unicamp, 2003.

BAUMAN, Zigmunt. O mal-estar da pós-modernidade. Rio de Janeiro: Jorge Zahar, 1998.

BENJAMIM, Walter. Magia e técnica, arte e política: ensaios sobre literatura e história da cultura. São Paulo: Brasiliense, 1994 - (Obras escolhidas volume 1)

BHABHA, Homi. O local da cultura (Pedagógico e performático). Belo Horizonte. Editora UFMG, 1998.

BOSI, Alfredo. História concisa da literatura brasileira. São Paulo: Cultrix, 2006.

Literatura e resistência. São Paulo: Companhia das Letras, 2002. 
CANCLINI, Néstor García. A globalização imaginada. São Paulo: Editora Iluminuras, 2007.

. Consumidores e cidadãos - Conflitos multiculturais da globalização. Rio de Janeiro: Editora UFRJ, 1997.

CANDIDO, Antonio. Formação da literatura brasileira: momentos decisivos. Rio de Janeiro: Ouro sobre azul, 2006. . "Literatura e Cultura de 1900 a 1945". In: Literatura $e$ Sociedade. Ouro sobre Azul, Rio de Janeiro: 2006. . "Literatura e subdesenvolvimento". In: Educação pela noite. Rio de Janeiro: Ouro sobre Azul, 2006.

CARNEIRO, Flávio. No país do presente: ficção brasileira no início do século XXI. Rio de Janeiro: Rocco, 2005.

CASTRO, Márcia Cerrano. A construção do literário na prosa narrativa de Luiz Ruffato. Tese de doutorado do Programa de Pós-Graduação em Letras Vernáculas da Universidade Federal do Rio de Janeiro, 2010. Orientadora: Professora Doutora Rosa Maria de Carvalho Gens, Co-orientadora: Professora Doutora Maria Eugenia Lamoglia Duarte.

CHARTEJEE, Partha. La nación en tempo heterogéneo y otros estudios subalternos. Buenos Aires: sieglo Veinteuno, 2008.

CUNHA, Eneida Leal. "Literatura e identidade". In: Revista do Centro de Estudos Portugueses Hélio Simões. Universidade Estadual de Santa Cruz, Departamento de Letras e Artes, n. 1 (1997 - 1998). Ilhéus: Editus, 1998.

DAMATTA, Roberto. Carnaval, malandros e heróis (Rio de Janeiro: Rocco, 1997, p.187)

DALCASTAGNE, Regina. Literatura brasileira contemporânea: território em disputa. Vinhedo, Editora Horizonte / Rio de Janeiro, Editora UERJ, 2012.

DEALTRY, Giovanna. In: Revista de Estudos de Literatura Brasileira Contemporânea, no. 34. Brasília, julho-dezembro de 2009, pp. 209-221. 
- "O romance relâmpago de Luiz Ruffato: um projeto literário-político em tempos pós-utópicos". In: Alguma prosa: ensaios sobre literatura brasileira contemporânea (org.): Giovanna Deatry, Masé Lemos, Stefania Chiarelli. Rio de Janeiro: 7Letras, 2007.

FIGUEIREDO, Vera Follain. "Central do Brasil - Em busca da terra prometida". Cinemais, n. 15, jan, / fev. 1999.

Da profecia ao labirinto: imagens da história na ficção latino-americana contemporânea. Rio de Janeiro: Imago / Ed. UERJ, 1994.

GOMES, Laurentino. 1808: Como uma rainha louca, um príncipe medroso e uma corte corrupta enganaram Napoleão e mudaram a História de Portugal e do Brasil. São Paulo: Editora Planeta do Brasil, 2007.

GOMES, Renato C. "Babel do século XXI: do mito às mídias". In: Revista da Associação Nacional dos Programas de Pós-graduação em Comunicação. Ecompós, Brasília, v. 11, n.1, jan. / abr. 2008.

. "Duas ou três coisas que eu sei dela". In: Alguma prosa: ensaios sobre literatura brasileira contemporânea. Org. Giovanna Dealtry, Masé Lemos e Stefania Chiarelli. Rio de Janeiro: 7 Letras, 2007.

- "Heranças, espectros, resíduos: imaginar a nação em tempos heterogêneos". In: Possibilidades da nova escrita literária no Brasil. Rio de Janeiro: Editora Renavan / Faperj, 2014.

. "Matrizes culturais e formatos industriais: uma série brasileira de televisão". In: $15^{\circ}$ Encontro Anual da COMPÓS. UNESP - Bauru, 6 a 9 de junho de 2006 .

. "Que faremos desta tradição? Ou relíquias da casa velha". In: Figuras da Lusofonia. Org. Izabel Margato. Lisboa: Instituto Camões, 2002. . "Móbiles urbanos: eles eram muitos..." In: Uma cidade em camadas - ensaios sobre o romance Eles eram muitos cavalos, de Luiz Ruffato (Org. Marguerite Itamar Harrison). São Paulo: Editora Horizonte, 2007. 
- Resenha de "Nações literárias", de Wander Melo de Miranda. O Globo, Prosa \& Verso 09/05/2012.

HALL, Stuart. A identidade cultural na pós-modernidade. Rio de Janeiro: DP\&A, 2006.

HELENA, Lúcia. A narrativa de fundação: Iracema, Macunaíma e viva o povo brasileiro. Congresso de Letras. Santa Maria, Jul / Dez de 1993.

. “Que globalização, que país, que literatura?” In: Nação-invenção: ensaios sobre o nacional em tempos de globalização. Org. Lúcia Helena. Rio de Janeiro: Contra Capa livraria / CNPQ, 2004.

. Literatura e diferença. Congresso Abralic. Anais. São Paulo, julago 1994 (525-530).

HOLLANDA, Heloísa Buarque de. "Crônica marginal”. In: Possibilidades da nova escrita literária no Brasil. Rio de Janeiro: Editora Renavan / Faperj, 2014.

HOSNE, Andrea Saad. "Degradação e acumulação: considerações sobre algumas obras de Luiz Ruffato". In: Uma cidade em camadas - ensaios sobre o romance Eles eram muitos cavalos, de Luiz Ruffato (Org. Marguerite Itamar Harrison). São Paulo: Editora Horizonte, 2007.

JABOR, Arnaldo. "O Brasil está com ódio de si mesmo". O Globo, Segundo Caderno, 06/05/2014, pg. 10.

JAMESON, Fréderic. "A literatura do terceiro mundo na era do capital multinacional”. Revista Social Text no. 15. Versão 1986, p. 65-88.

JÚNIOR, Caio Prado. "Formação do Brasil contemporâneo". In: Intérpretes do Brasil. Coordenação, seleção de livros e prefácio, Silviano Santiago. Rio de Janeiro: Nova Aguilar, 2000.

LOBO, Rosana. Amores expressos: narrativas do não-pertencimento. Dissertação de mestrado. Departamento de Letras da PUC-Rio. 2010. Orientação: Renato Cordeiro Gomes. 
"Um matuto ingênuo e bastante carismático". In: Jornal do Brasil, Ideias, 03/10/2009.

MACEDO, Carmen Cinira. Imagem do eterno: religiões no Brasil. Rio de Janeiro: Editora Moderna, 1989.

MELLO, Jefferson Agostini. Permanência do provisório, (USP). Novos Estudo CEBRAP, n. 74, São Paulo, Mar. 2006

MIRANDA, Wander Mello. Nações literárias. Cotia, SP: Ateliê Editorial, 2010.

MORAES, Eduardo Jardim de. "Modernismo revisitado", In: Estudos históricos, v. 1, n. 2, 1988. . “O que significa ir além das fronteiras?". In:

Revista Semear 6. Cátedra Padre António Vieira, PUC-Rio, 2002.

MELLO \& NOVAIS, João Manuel Cardoso e Fernando A. A que ponto chegamos. In: A que ponto chegamos: balanço do governo fhcardoso e perspectivas da oposição. Revista Praga: estudos marxistas, n. 6, setembro de 1998.

NEUMANE, José. "A São Paulo terna e brutal do mineiro Ruffato". Estado de S. Paulo, 06/01/2002.

NOVAES, Adauto (org). A crise do Estado-Nação. Rio de Janeiro: Civilização Brasileira, 2003.

ORTIZ, Renato. "Globalização, modernidade e cultura". In: Revista Semear 6, Cátedra Padre António Vieira, PUC-Rio, 2002.

OLINTO, Heirun Krieger. "Como falar de histórias (de literatura) hoje?" In: Revista Palavras. Rio de Janeiro: Trarepa, 2000, p. 114-123.

OLIVEIRA, Marcos Vinícius Ferreira de. Tecido em Ruínas: fabricação e corrosão das Cataguases no Inferno provisório de Luiz Ruffato. São Paulo: Editora Intermeios, 2013. 
PORTO, Alexandre Vidal. "O país dos pipoqueiros". Folha de S. Paulo, 12/10/2013. A22.

RENAN, Ernest. "O que é uma nação?”. In: Nacionalidade em questão Org. Maria Helena Rouanet. Universidade do Estado do Rio de Janeiro - I.L - 1997.

RESENDE, Beatriz. Contemporâneos: Expressões da literatura brasileira no século XXI. Rio de Janeiro: Casa da Palavra: Biblioteca Nacional, 2008.

- Possibilidades da nova escrita literária no Brasil. Rio de Janeiro: Editora Renavan / Faperj, 2014.

RIEDEL, Dirce Côrtes (org.). Narrativa, ficção e história. Rio de Janeiro: Imago, 1988.

RUFFATO, Luiz. Eles eram muitos cavalos. São Paulo: Boitempo Editorial, 2001.

Estive em Lisboa e lembrei de você. São Paulo: Companhia das Letras, 2009.

. "Até aqui tudo bem! (como e porque sou romancista - versão século 21)”. In: Espécies de espaço: territorialidades, literatura, mídia. Izabel Margato, Renato Cordeiro Gomes (Org). Belo Horizonte: Editora UFMG, 2008.

Domingos sem Deus. Rio de Janeiro: Record, 2011.

(org.) Fora da ordem e do progresso. São Paulo: Geração editorial, 2004.

. Mamma, son tanto Felice. Rio de Janeiro: Record, 2005.

. O homem que tece. Juiz de Fora: Rosetá Publicações, 1979.

O livro das impossibilidades. Rio de Janeiro: Record, 2008.

O mundo inimigo. Rio de Janeiro: Record, 2005.

. Vista parcial da noite. Rio de Janeiro: Record, 2006. 
SAID, Edward. Reflexões sobre o exílio e outros ensaios. São Paulo: Companhia das Letras, 2003.

SANTIAGO, Silviano. O Cosmopolitismo do pobre. Belo Horizonte: Editora UFMG, 2004. . "O entre-lugar do discurso latino-americano". In: Uma literatura nos trópicos: ensaios sobre a dependência cultural. Rio de Janeiro: Rocco, 2000.

SANTOS, Roberto Corrêa dos. "O político e o psicológico, estágios da cultura". In: Modos de saber, modos de adoecer: o corpo, a arte, o estilo, a história, a vida. Belo Horizonte: Ed UFMG, 1999.

SCHWARZ, Roberto. "Nacional por subtração". In: Que horas são? São Paulo: Companhia das Letras, 1987.

SOMMER, Dóris. “Amor e pátria na América Latina: uma especulação alegórica sobre sexualidade e patriotismo". Papéis avulsos, n. 10, 1989

SUKMAN, Hugo. “A canção moderna: uma cidade bonitinha e má ou os dois sentidos da palavra arrastão". In: Canções do Rio: a cidade em letra e música. Rio de Janeiro: Casa da Palavra, 2009.

SUSSEKIND, Flora. Tal Brasil, qual romance? Rio de Janeiro: Achiamé, 1984.

TELLES, Vera da Silva. “A 'nova questão social' brasileira”. In: A que ponto chegamos: balanço do governo fhcardoso e perspectivas da oposição. Revista Praga: estudos marxistas, n. 6, setembro de 1998.

TRIGO, Luciano. O facebook ajuda a entender o Brasil. O Globo, 22/03/2014.

VENTURA, Zuenir. “A onda de mau humor”. O Globo, 04/06/2014. P. 21.

WILLIAMS, Raymmond. "Residual, dominante e emergente". In: Literatura e Marxismo. Rio de Janeiro: Editora Zahar, 1979. 
Sites:

BRASIL, Ubiratan. Luiz Ruffato e o sonho do paraíso na metrópole. Estado de S. Paulo (08/10/2012). http://cultura.estadao.com.br/noticias/geral,luiz-ruffato-e-osonho-do-paraiso-na-metropole,255636 Acesso em 09/06/2014.

CERQUEIRA, Rodrigo da Silva. Ordem e dominação em Mamma, son tanto Felice, de Luiz Ruffato. http://www.ufjf.br/darandina/files/2010/01/Rodrigo-daSilva-Cerqueira.pdf Acesso em 10/03/2014.

GULLAR, Ferreira. Roteiro Singular (http: //ptscribd.com/doc/77806670//GullarSingular) Acesso em Junho de 2012.

RUFFATO, Luiz. http://www.bienalpernambuco.com/\%E2\%80\%9Cos-invisiveis\%E2\%80\%93-a-literatura-proletaria-brasileira-palestra-de-luiz-ruffato-na-bienal/ acesso em $07 / 03 / 2012$.

RODRIGUES, Maria Fernanda. Escritor critica desigualdade no Brasil e divide opiniões em abertura da Feira de Frankfurt. http://cultura.estadao.com.br/noticias/geral,luiz-ruffato-e-o-sonho-do-paraiso-nametropole,255636 Acesso em 12/11/2013.

SANTIANO, "Formação Silviano. e inserção". http://cultura.estadao.com.br/noticias/geral,formacao-e-insercao-imp-,878251. Acesso em 07/06/2014. 


\section{Anexo I}

Discurso para a abertura da Feira de Frankfurt, em 8 de outubro de 2013

\section{Luiz Ruffato}

"O que significa ser escritor num país situado na periferia do mundo, um lugar onde o termo capitalismo selvagem definitivamente não é uma metáfora? Para mim, escrever é compromisso. Não há como renunciar ao fato de habitar os limiares do século 21, de escrever em português, de viver em um território chamado Brasil. Fala-se em globalização, mas as fronteiras caíram para as mercadorias, não para o trânsito das pessoas. Proclamar nossa singularidade é uma forma de resistir à tentativa autoritária de aplainar as diferenças.

O maior dilema do ser humano em todos os tempos tem sido exatamente esse, o de lidar com a dicotomia eu-outro. Porque, embora a afirmação de nossa subjetividade se verifique através do reconhecimento do outro --é a alteridade que nos confere o sentido de existir--, o outro é também aquele que pode nos aniquilar... E se a Humanidade se edifica neste movimento pendular entre agregação e dispersão, a história do Brasil vem sendo alicerçada quase que exclusivamente na negação explícita do outro, por meio da violência e da indiferença.

Nascemos sob a égide do genocídio. Dos quatro milhões de índios que existiam em 1500, restam hoje cerca de 900 mil, parte deles vivendo em condições miseráveis em assentamentos de beira de estrada ou até mesmo em favelas nas grandes cidades. Avoca-se sempre, como signo da tolerância nacional, a chamada democracia racial brasileira, mito corrente de que não teria havido dizimação, mas assimilação dos autóctones. Esse eufemismo, no entanto, serve apenas para acobertar um fato indiscutível: se nossa população é mestiça, deve-se ao cruzamento de homens europeus com mulheres indígenas ou africanas - ou seja, a assimilação se deu através do estupro das nativas e negras pelos colonizadores brancos.

Até meados do século 19, cinco milhões de africanos negros foram aprisionados e levados à força para o Brasil. Quando, em 1888, foi abolida a escravatura, não houve qualquer esforço no sentido de possibilitar condições dignas aos ex-cativos. Assim, até hoje, 125 anos depois, a grande maioria dos afrodescendentes continua 
confinada à base da pirâmide social: raramente são vistos entre médicos, dentistas, advogados, engenheiros, executivos, jornalistas, artistas plásticos, cineastas, escritores.

Invisível, acuada por baixos salários e destituída das prerrogativas primárias da cidadania --moradia, transporte, lazer, educação e saúde de qualidade--, a maior parte dos brasileiros sempre foi peça descartável na engrenagem que movimenta a economia: $75 \%$ de toda a riqueza encontra-se nas mãos de $10 \%$ da população branca e apenas 46 mil pessoas possuem metade das terras do país. Historicamente habituados a termos apenas deveres, nunca direitos, sucumbimos numa estranha sensação de não pertencimento: no Brasil, o que é de todos não é de ninguém...

Convivendo com uma terrível sensação de impunidade, já que a cadeia só funciona para quem não tem dinheiro para pagar bons advogados, a intolerância emerge. Aquele que, no desamparo de uma vida à margem, não tem o estatuto de ser humano reconhecido pela sociedade, reage com relação ao outro recusando-lhe também esse estatuto. Como não enxergamos o outro, o outro não nos vê. E assim acumulamos nossos ódios --o semelhante torna-se o inimigo.

A taxa de homicídios no Brasil chega a 20 assassinatos por grupo de 100 mil habitantes, o que equivale a 37 mil pessoas mortas por ano, número três vezes maior que a média mundial. E quem mais está exposto à violência não são os ricos que se enclausuram atrás dos muros altos de condomínios fechados, protegidos por cercas elétricas, segurança privada e vigilância eletrônica, mas os pobres confinados em favelas e bairros de periferia, à mercê de narcotraficantes e policiais corruptos. Machistas, ocupamos o vergonhoso sétimo lugar entre os países com maior número de vítimas de violência doméstica, com um saldo, na última década, de 45 mil mulheres assassinadas. Covardes, em 2012 acumulamos mais de 120 mil denúncias de maus-tratos contra crianças e adolescentes. E é sabido que, tanto em relação às mulheres quanto às crianças e adolescentes, esses números são sempre subestimados.

Hipócritas, os casos de intolerância em relação à orientação sexual revelam, exemplarmente, a nossa natureza. O local onde se realiza a mais importante parada gay do mundo, que chega a reunir mais de três milhões de participantes, a 
Avenida Paulista, em São Paulo, é o mesmo que concentra o maior número de ataques homofóbicos da cidade.

E aqui tocamos num ponto nevrálgico: não é coincidência que a população carcerária brasileira, cerca de 550 mil pessoas, seja formada primordialmente por jovens entre 18 e 34 anos, pobres, negros e com baixa instrução.

O sistema de ensino vem sendo ao longo da história um dos mecanismos mais eficazes de manutenção do abismo entre ricos e pobres. Ocupamos os últimos lugares no ranking que avalia o desempenho escolar no mundo: cerca de $9 \%$ da população permanece analfabeta e $20 \%$ são classificados como analfabetos funcionais --ou seja, um em cada três brasileiros adultos não tem capacidade de ler e interpretar os textos mais simples.

A perpetuação da ignorância como instrumento de dominação, marca registrada da elite que permaneceu no poder até muito recentemente, pode ser mensurada. O mercado editorial brasileiro movimenta anualmente em torno de 2,2 bilhões de dólares, sendo que $35 \%$ deste total representam compras pelo governo federal, destinadas a alimentar bibliotecas públicas e escolares. No entanto, continuamos lendo pouco, em média menos de quatro títulos por ano, e no país inteiro há somente uma livraria para cada 63 mil habitantes, ainda assim concentradas nas capitais e grandes cidades do interior.

Mas, temos avançado.

A maior vitória da minha geração foi o restabelecimento da democracia - são 28 anos ininterruptos, pouco, é verdade, mas trata-se do período mais extenso de vigência do estado de direito em toda a história do Brasil. Com a estabilidade política e econômica, vimos acumulando conquistas sociais desde o fim da ditadura militar, sendo a mais significativa, sem dúvida alguma, a expressiva diminuição da miséria: um número impressionante de 42 milhões de pessoas ascenderam socialmente na última década. Inegável, ainda, a importância da implementação de mecanismos de transferência de renda, como as bolsas-família, ou de inclusão, como as cotas raciais para ingresso nas universidades públicas.

Infelizmente, no entanto, apesar de todos os esforços, é imenso o peso do nosso legado de 500 anos de desmandos. Continuamos a ser um país onde moradia, educação, saúde, cultura e lazer não são direitos de todos, mas privilégios de alguns. Em que a faculdade de ir e vir, a qualquer tempo e a qualquer hora, não 
pode ser exercida, porque faltam condições de segurança pública. Em que mesmo a necessidade de trabalhar, em troca de um salário mínimo equivalente a cerca de 300 dólares mensais, esbarra em dificuldades elementares como a falta de transporte adequado. Em que o respeito ao meio-ambiente inexiste. Em que nos acostumamos todos a burlar as leis.

Nós somos um país paradoxal.

Ora o Brasil surge como uma região exótica, de praias paradisíacas, florestas edênicas, carnaval, capoeira e futebol; ora como um lugar execrável, de violência urbana, exploração da prostituição infantil, desrespeito aos direitos humanos e desdém pela natureza. Ora festejado como um dos países mais bem preparados para ocupar o lugar de protagonista no mundo --amplos recursos naturais, agricultura, pecuária e indústria diversificadas, enorme potencial de crescimento de produção e consumo; ora destinado a um eterno papel acessório, de fornecedor de matéria-prima e produtos fabricados com mão de obra barata, por falta de competência para gerir a própria riqueza.

Agora, somos a sétima economia do planeta. E permanecemos em terceiro lugar entre os mais desiguais entre todos...

Volto, então, à pergunta inicial: o que significa habitar essa região situada na periferia do mundo, escrever em português para leitores quase inexistentes, lutar, enfim, todos os dias, para construir, em meio a adversidades, um sentido para a vida?

Eu acredito, talvez até ingenuamente, no papel transformador da literatura. Filho de uma lavadeira analfabeta e um pipoqueiro semianalfabeto, eu mesmo pipoqueiro, caixeiro de botequim, balconista de armarinho, operário têxtil, torneiro-mecânico, gerente de lanchonete, tive meu destino modificado pelo contato, embora fortuito, com os livros. E se a leitura de um livro pode alterar o rumo da vida de uma pessoa, e sendo a sociedade feita de pessoas, então a literatura pode mudar a sociedade. Em nossos tempos, de exacerbado apego ao narcisismo e extremado culto ao individualismo, aquele que nos é estranho, e que por isso deveria nos despertar o fascínio pelo reconhecimento mútuo, mais que nunca tem sido visto como o que nos ameaça. Voltamos as costas ao outro --seja ele o imigrante, o pobre, o negro, o indígena, a mulher, o homossexual-- como tentativa de nos preservar, esquecendo que assim implodimos a nossa própria condição de existir. Sucumbimos à solidão e ao egoísmo e nos negamos a nós 
mesmos. Para me contrapor a isso escrevo: quero afetar o leitor, modificá-lo, para transformar o mundo. Trata-se de uma utopia, eu sei, mas me alimento de utopias. Porque penso que o destino último de todo ser humano deveria ser unicamente esse, o de alcançar a felicidade na Terra. Aqui e agora." 


\section{Anexo II}

\section{Entrevista de Luiz Ruffato concedida por e-mail em 26/08/2014}

Rosana Lobo - Nos 5 volumes de Inferno provisório, você usa como epígrafe um verso de Jorge de Lima sobre naus que não chegam a lugar nenhum porque já estão podres desde o tronco da árvore de que foram retiradas. Essa imagem pode servir de metáfora para o país? Uma nação que não chega a lugar algum por conta de suas instituições carcomidas desde a origem?

Luiz Ruffato - Sim, creio que essa poderia ser a epígrafe da História do Brasil, um país que foi se construindo como um acampamento provisório, em que as pessoas, todas elas, pertençam à elite ou ao proletariado, vêem como uma terra não de promissão, mas de permissão. Aqui, parece, todos agem como animais predatórios. Não há a consciência do bem comum.

RL - Nota-se que os problemas que aparecem no quinto volume - Brasil urbano / século XXI - já estavam postos no $1^{\circ}$ volume, que se passa no Brasil rural, década de 1950: racismo, precariedade da educação, completa ausência do Estado, falta de perspectiva... Pode-se dizer que os problemas do Brasil de hoje já estavam postos desde sempre?

LR - Há uma espécie de ciclo que se repete infinitamente, como vivêssemos presos à circularidade da história, que é uma tese interessante, defendida por Gabriel García Márquez, em Cem Anos de Solidão, ficcionalmente, e por alguns historiadores. Ou se quisermos, a história vista não como uma evolução linear, que é uma perspectiva escatológica, em direção à redenção cristã, mas como uma evolução espiralada, em que os fatos do passado e do presente estão mais próximos que se imagina. Por isso, a dificuldade de se resolver esses problemas. Eles estão no nascimento do Brasil - e, ao invés de serem extirpados, crescem com ele.

RL - Nota-se que em Domingos sem Deus, cuja última história remonta a 2002, paira o sentimento de uma 'pobreza irremediável'. Mas, o seu discurso em Frankfurt, em 2013, aponta para a esperança na redemocratização e no surgimento de políticas assistenciais. Você acredita que podemos voltar a ter esperança? 
LR- Não acredito em resolução de problemas por meio de políticas assistenciais (como as de transferência de renda) nem por meio de cotas. Mas defendo esses dois mecanismos como políticas compensatórias para diminuir as diferenças absurdas entre as camadas da sociedade brasileira. É inegável que houve mudanças importantes advindas neste curto interregno democrático. Falta, sem dúvida alguma, o passo seguinte, que é transformar a sociedade para que essas medidas paliativas sejam desnecessárias, e portanto extintas.

RL - Para você o Brasil é o país do futuro?

LF - A minha concepção de tempo não compreende o futuro. O futuro é o aqui e a agora do presente.

RL - Como a literatura de uma maneira geral, e Inferno provisório em particular, podem contribuir para a construção de uma sociedade mais cidadã?

LR - São esforços pequenos, ínfimos, mas, no meu ponto de vista, importantes, porque as artes em geral contribuem para o oferecimento de uma reflexão. Eu acredito que a leitura de um livro abre as portas da percepção. Um bom livro é aquele que transforma o leitor. Se a sociedade é feita de pessoas, e se o livro pode transformar uma pessoa, logo o livro pode transformar a sociedade. É pouco, é ínfimo, mas é a minha contribuição sincera.

RL - Roberto Schwarz afirma que, na década de 1970, a entrada da cultura estrangeira no país através dos meios de comunicação de massa fez com que a afirmação das nossas singularidades passassem a fazer papel de "velharia" e "provincianismo". Você concorda? De que forma acha que devemos proclamar as nossas singularidades (e quais seriam elas) para resistir à tentativa autoritária da globalização de aplainar as diferenças?

LR - A globalização é uma balela vendida como esforço democrático do sistema capitalista neoliberal. A globalização é para as mercadorias - ainda assim com restrições - não para as pessoas. Muito ao contrário, o cenário que se desenha é de aumento da radicalização das posições, exatamente porque não se compreende ou não se quer compreender as singularidades. A xenofobia é o assassinato do outro, seja a praticada por europeus branco com relação a árabes, negros ou terceiromundistas, seja a praticada por muçulmanos, brancos ou negros, contra todos que não forem muçulmanos, seja a praticada por brasileiros contra os índios, bolivianos, cubanos, etc... Afirmar nossa singularidade é uma maneira de oferecer 
ao outro a oportunidade de praticar o discurso da diversidade. Apagar os traços da singularidade é matar o outro.

RL - O geógrafo Milton Santos acreditava na existência de uma globalização solidária. Você acha possível?

LR - Não acredito na globalização.

RL - Seu romance mais recente, Flores artificiais, já não se ocupa aparentemente de denunciar / interpretar os problemas do país. A sua missão de inserir na História, através de sua obra, personagens marginalizados, destituídos das prerrogativas básicas da cidadania se encerra em Inferno provisório?

LR - Não concordo com a premissa. Falando do outro, de outras realidades, de outras visões de mundo, estou, por contraste, falando do Brasil. E, a bem da verdade, não é porque desloco os cenários para outras paisagens que deixo de tentar interpretar as mazelas do meu país. 